\title{
IMPACT OF PANDEMIC \\ ON \\ WOMEN EMPOWERMENT
}

Fatitors

Dr. R. Radhika Devi

Dr. C. Subbulakshmi

In Collaboration with

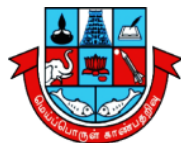

Women's Studies Centre

Madurai Kamaraj University, Madurai

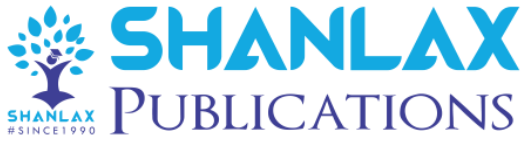




\author{
(C) Dr. R. Radhika Devi \& Dr. C. Subbulakshmi
}

First Edition: September 2020

ISBN: 978-93-90082-44-5

\title{
Copyright
}

All rights reserved. No part of this book may be reproduced, stored in a retrieval system or transmitted, in any form or by any means, mechanical, photocopying, recording or otherwise, without prior written permission of the Editor.

\section{Publisher}

SHANLAX PUBLICATIONS

61, 66 T.P.K. Main Road

Vasantha Nagar

Madurai - 625003
Ph: 0452-4208765,

Mobile: 7639303383

email:publisher@shanlaxpublications.com

web: www.shanlaxpublications.com 


\section{PREFACE}

Empowering women is the need of the hour. Woman is getting education, healthcare, safety, equal opportunity, a life of independence and dignity has been a mission for visionaries around the globe. As per a report by McKinsey, an estimated $\$ 770$ billion would be added to India's economy by 2025, if gender equality is effectively achieved in the country.

However, the mission and hopes of millions of women and men to empower every woman in the world have come to a sudden pause during the recent pandemic of Coronavirus disease or COVID-19 which has infected over 3 million people globally in the last five months.

COVID-19 is unique because of (1) its wide geographic spread across a range of populations, (2) its partially asymptomatic transmission, (3) a disproportionate effect on older people and those with underlying morbidities, and (4) potentially, the level of intensive care required when geographic areas experience a large number of severe cases. Many countries and states have chosen to place entire populations under lockdown to reduce mortality and mitigate the potential burden on health systems.

As per the United Nations Population Fund (UNFPA), a woman is affected thrice as much as a man due to this epidemic. A working woman with children now is working from home, doing household duties, taking care of kids, and now also needs to pay attention to homeschooling her children to prevent them from having a mental breakdown from being locked inside the house all the time. This is the "triple shift," i.e., three times the amount of stress a woman is suffering from due to the COVID-19 pandemic.

These restrictions are essential, but they increase the risk of violence towards women trapped with abusive partners. Recent weeks have seen an alarming global surge in domestic violence; the largest support organisation in the U.K. reported a 700\% increase in calls. At the same time, support services for women at risk face cuts and closures.

The COVID-19 pandemic has highlighted the need to examine the impact of the crisis through a gender lens - from how lockdowns and stay at home orders can impinge on the rights of women, including increasing the risks of gender-based violence to the economic impact of the crisis on women who are more likely to work in the informal sector and are disproportionately impacted by the economic consequences. In broader terms, the rule of law and access to justice remains the foundation through which people can uphold their rights, seek redress for grievances, and protect those who are most at risk of being left behind, regardless of the necessities of our time.

We celebrate the frontline healthcare workers, who are predominantly women, for their dedication and commitment to fight this common cause. At the same time, we need to ensure that even when justice systems are under stress, access to justice and accountability for violations of fundamental rights cannot be undermined. They should be part of the essential services that need to continue to function in times of crisis. 
The Women's Empowerment Principles help to achieve gender equality in the workplace, market place and community and can guide each and everyone in recognizing and responding to the gender-specific impacts of COVID-19.

This book may be used as a companion piece for Women Empowerment in a pandemic situation. It presents a comprehensive overview of the challenges and opportunities that women face in their quest for justice on gender equality and women's empowerment. It contextualizes them in the current situation where countries and communities are seeking to address the heightened challenges presented by the COVID-19 crisis and recover from its devastating effects.

Dr. R. Radhika Devi 


\section{CONTENTS}

\begin{tabular}{|c|c|c|}
\hline $\begin{array}{c}\text { S. } \\
\text { No. }\end{array}$ & Chapter Title & $\begin{array}{c}\text { Page } \\
\text { No. }\end{array}$ \\
\hline 1 & $\begin{array}{l}\text { An Empirical Study on Occupational Stress of Women } \\
\text { Teachers During Pandemic } \\
\text { Dr. C. Subbulakshmi }\end{array}$ & 1 \\
\hline 2 & $\begin{array}{l}\text { Impact of COVID } 19 \text { on Women Entrepreneurs- } \\
\text { Oppertunities and Challenges in Informal Sectors } \\
\text { T. Booma }\end{array}$ & 4 \\
\hline 3 & $\begin{array}{l}\text { COVID - } 19 \text { and Women in Developing Countries } \\
\text { S. Suganya }\end{array}$ & 8 \\
\hline 4 & $\begin{array}{l}\text { The Care Economy for Women: } \\
\text { COVID-19 Transformative Policy } \\
\text { Dr. Bhagyalakshmi Rajaram }\end{array}$ & 13 \\
\hline 5 & $\begin{array}{l}\text { Self Help Group - A Firearm against Pandemic } \\
\text { Dr. R. Radhika Devi }\end{array}$ & 20 \\
\hline 6 & $\begin{array}{l}\text { The Perceived Stress of Women as Victims or Warriors of } \\
\text { COVID-19 Pandemic } \\
\text { Dr. B. Winmayil }\end{array}$ & 25 \\
\hline 7 & $\begin{array}{l}\text { Safety, Security and Well Being in Times of COVID } 19 \\
\text { Dr. M.A. Israth Jahan }\end{array}$ & 31 \\
\hline 8 & $\begin{array}{l}\text { Elderly Women's Spirituality and Well-Being: Scrutinizing } \\
\text { the Dimensions of Religiosity and Spirituality for } \\
\text { Empowerment in Post-Pandemic Times } \\
\text { Dr. Irum Alvi }\end{array}$ & 40 \\
\hline 9 & $\begin{array}{l}\text { Health Anxiety among Female Students During COVID -19 } \\
\text { Dr. K. Vellaichamy }\end{array}$ & 47 \\
\hline 10 & $\begin{array}{l}\text { Effects of Socio-Psychological, Political and Educational } \\
\text { Impact of Women } \\
\text { P N Vinod Kumar }\end{array}$ & 51 \\
\hline 11 & $\begin{array}{l}\text { Violence against Women and COVID } 19 \text { Pandemic: } \\
\text { A Symbiosis } \\
\text { Mrs. K. Priyadarshini }\end{array}$ & 59 \\
\hline 12 & $\begin{array}{l}\text { The Critical Role of Mass Media During Covid-19 Pandemic } \\
\text { Dr. T. Subhashini }\end{array}$ & 64 \\
\hline 13 & $\begin{array}{l}\text { Entrepreneurs in the Path of COVID } \\
\text { Mr. N. Jegatheesan }\end{array}$ & 70 \\
\hline 14 & $\begin{array}{l}\text { Role of Feminism in Women Empowerment During } \\
\text { Pandemic through Literary Characters } \\
\text { Dr. S. Udhayakumar }\end{array}$ & 74 \\
\hline
\end{tabular}




\begin{tabular}{|c|c|c|}
\hline 15 & $\begin{array}{l}\text { Women's Caring Responsibilities in COVID-19 } \\
\text { Dr. S. Chitra Devi }\end{array}$ & 80 \\
\hline 16 & $\begin{array}{l}\text { Safety, Security and Well-Being of Women in terms of } \\
\text { COVID-19 } \\
\text { Dr. R. Muthulakshmi }\end{array}$ & 84 \\
\hline 17 & $\begin{array}{l}\text { Need of Techno-Literacy among Women during } \\
\text { Pandemic COVID-19 } \\
\text { Dr. R. Sengamalam @ Vaanathi }\end{array}$ & 90 \\
\hline 18 & $\begin{array}{l}\text { How do Women View the Online Learning of their } \\
\text { Children? A Study of Alappuzha District } \\
\text { Dr. Pradeep Kumar B }\end{array}$ & 98 \\
\hline
\end{tabular}




\title{
AN EMPIRICAL STUDY ON OCCUPATIONAL STRESS OF WOMEN TEACHERS DURING PANDEMIC

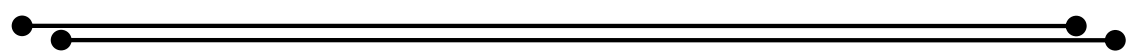

\author{
Dr. C. Subbulakshmi \\ Assistant Professor, Women's Studies Centre \\ Madurai Kamaraj University, Madurai
}

\begin{abstract}
Stress refers to the mental and emotional strain or tension resultant from unpleasant circumstances. Occupational stress is related to one's job. Occupational stress often stems from unexpected responsibilities and pressures that do not align with a person's knowledge, skills, or expectations, inhibiting one's ability to cope. 108 primary school women teachers were constituted from Madurai district. Conclusions of this study are Rural Nativity women teachers have more occupational stress than urban school teachers. Nuclear families of women teachers, Private school women teachers and Government and aided school teachers have more occupational stress in this pandemic period.
\end{abstract}

Keywords: Occupational stress and Women Teachers

\section{Need for the Study}

Pressure seeming as acceptable by an individual, may even keep workers alert, motivated, able to work and learn, depending on the available resources and personal characteristics. Though, when that pressure becomes extreme unmanageable it leads to stress. Stress can damage an employees' health and the business performance. Work-related stress can be caused by poor work organization by poor work design, poor management, inadequate working conditions, and lack of support from colleagues and supervisors during this pandemic period. When workplace stress is not controlled and properly channelized, it can create a lot of coping issues and unreliability. During this COVID-19 period, primary school teachers' stress is increasing for teaching online class, and online administration. Hence the need for the conduct of the present study which is entitled "OCCUPATIONAL STRESS OF WOMEN TEACHERS DURING PANDEMIC".

\section{Terms and Definitions}

Occupational stress - refers to the pressure from school management, parents, students and handling online classes.

Women Teachers - refers to those who are handling fist standard to fifth standard students in Madurai District.

\section{Variables of the Study}

\begin{tabular}{|l|c|c|}
\hline Dependent Variable & \multicolumn{2}{|c|}{ Independent variable } \\
\hline \multirow{4}{*}{ Occupational stress } & \multirow{2}{*}{ Nativity } & Male \\
\cline { 2 - 3 } & \multirow{2}{*}{ Family Type } & Female \\
\cline { 2 - 3 } & & Nuclear \\
\cline { 2 - 3 } & \multirow{2}{*}{ Type of School } & Government \&Aided \\
& & \multicolumn{2}{|c|}{ Private } \\
\hline
\end{tabular}




\section{Aims of this Research}

1. To quantify the stage of occupational stress among women teachers during pandemic period.

2. To enumerate, whether there is any significant difference among occupational stress among women teachers during pandemic period in terms of select independent variables involved in this study.

\section{Hypotheses of the Study}

1. Nativity exerts a significant influence on occupational stress among women teachers during pandemic period.

2. Family type exerts a significant influence on occupational stress among women teachers during pandemic period.

3. Type of school exerts a significant influence on occupational stress among women teachers during pandemic period.

\section{Methodology - In - Brief}

\section{Sample}

Random sample of 108 primary school women teachers from Madurai district.

\section{Tool}

The tool used for the data collection are as follows:

- Occupational stress inventory was constructed and standardized by the investigator.

- General information sheet structured by the investigator.

\section{Statistical Treatments}

1. ' $\mathrm{t}$ ' test

2. Pearson Product Moment Correlation ' $r$ '

\section{Data Collection Procedure}

The scale on Occupational Stress and general Information Sheet were administered in the select Primary School Women Teachers through online mode.

\section{Result and Discussions}

Hypothesis 1: Nativity exerts a significant influence on occupational stress among women teachers during pandemic period.

Table 1: Occupational Stress of Women School Teachers - Nativity -Wise

\begin{tabular}{|c|c|c|c|c|c|c|}
\hline Variable & Sub-variables & $\mathbf{N}$ & Mean & S.D & 't' value & Significance at 0.05 level \\
\hline \multirow{2}{*}{ Nativity } & Rural & 76 & 48.54 & 10.03 & \multirow{2}{*}{2.391} & \multirow{2}{*}{ Significant } \\
\cline { 2 - 5 } & Urban & 32 & 43.64 & 9.76 & & \\
\hline
\end{tabular}

The estimated ' $t$ ' value (2.391) is greater than the critical value 1.96 at 0.05 level of significance. This indicates that rural school women teachers have more occupational stress than urban school teachers. Hence the hypothesis 1 is accepted. 
Hypothesis 2: Family type exerts a significant influence on occupational stress among women teachers during pandemic period.

Table 2: Occupational Stress of Women School Teachers - Family Type -Wise

\begin{tabular}{|c|c|c|c|c|c|c|}
\hline Variable & Sub-variables & $\mathbf{N}$ & Mean & S.D & 't' value & Significance at 0.05 level \\
\hline \multirow{2}{*}{ Family Type } & Nuclear & 53 & 49.75 & 10.54 & \multirow{2}{*}{3.213} & \multirow{2}{*}{ Significant } \\
\cline { 2 - 5 } & Joint & 55 & 43.87 & 8.31 & & \\
\hline
\end{tabular}

The estimated ' $t$ ' value 3.213 is greater than the critical value 1.96 at 0.05 level of significance. This indicates that women teachers those who belong to nuclear families have more occupational stress than who belong to joint families. Hence the hypothesis 2 is accepted.

Hypothesis 3: Type of school exerts a significant influence on occupational stress among women teachers during pandemic period.

Table 3: Occupational Stress of Women School Teachers - Type Of School -Wise

\begin{tabular}{|c|c|c|c|c|c|c|}
\hline Variable & Sub-variables & $\mathbf{N}$ & Mean & S.D & 't' value & Significance at 0.05 level \\
\hline \multirow{2}{*}{ Type of school } & $\begin{array}{c}\text { Government } \\
\text { \& Aided }\end{array}$ & 48 & 40.37 & 7.15 & \multirow{2}{*}{-4.949} & Significant \\
\cline { 2 - 6 } & Private & 60 & 49.03 & 10.97 & & \\
\hline
\end{tabular}

The estimated ' $t$ ' value -4.949 is greater than the critical value 1.96 at 0.05 level of significance. This indicates that women teachers those who belong to Private school teachers have more occupational stress than who belong to Government and aided school teachers. Hence the hypothesis 3 is accepted.

\section{Findings of the Study}

1. Rural Nativity women teachers have more occupational stress than Urban school teachers.

2. Nuclear families women teachers have more occupational stress than Joint families teachers.

3. Private school women teachers have more occupational stress than Government and aided school teachers.

\section{References}

1. https://arseam.com/sites/default/files/published-papers/p4i9v5hrir-\%20full\%2037-44\%20Dr.\%20Nasreen\%20Qusar-\%20Sep-2018.pdf

2. http://ierj.in/journal/index.php/ierj/article/view/792

3. http://www.diva-portal.org/smash/get/diva2:1120081/FULLTEXT01.pdf

4. https://www.researchgate.net/publication/329969713_Job_Stress_among_Female_ Teachers_of_Rural_Primary_School

5. https://www.ripublication.com/ijepa/ijepav1n2_7.pdf 


\title{
IMPACT OF COVID 19 ON WOMEN ENTREPRENEURS- OPPERTUNITIES AND CHALLENGES IN INFORMAL SECTORS

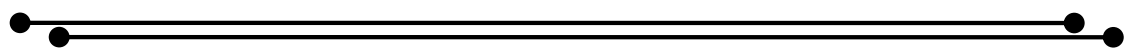

\author{
T. Booma \\ Research Scholar, Department of Commerce \\ Madurai Kamaraj University, Madurai
}

\begin{abstract}
This chapter makes an attempt to analyze the opportunities and challenges of Women entrepreneur in informal sector during COVID 19 pandemic. For any country, economic growth and entrepreneurship plays an important role as these factors determine the sustainable development of the country. Today women entrepreneurship plays a significant role in economic empowerment. Women entrepreneurs need to increase their standard of living as it helps to develop the economy. They are coming up not only from the elite business families or higher-income sections, but also from all walks of the country. Women's employment will certainly be impacted as the Indian economy is expected to go into a severe downturn due to COVID 19 pandemic. There is remarkable evidence that COVID-19 has strong effect on women and diverse groups due to structural inequality such as wage gap and also, they bear the brunt of unpaid work including elder/child care, household duties all of which have become more challenging during this pandemic as schools and other services are closed down.
\end{abstract}

Keywords: Women entrepreneur, Informal sector, Economic empowerment, COVID 19 pandemic crisis, Economic vulnerability, Sustainable development.

\section{Introduction}

Entrepreneur is a person who starts his own business and is willing to accept risk in order to make more profit. He should be capable enough to forecast the prospects and problems of an enterprise and also organize various factors of production including men, material, money and methods. She is expected to manage all the affairs of the business and to innovate new things or imitate existing things. The Government of India has defined women entrepreneurs based on women participation in equity and employment of business enterprises. Accordingly, the women entrepreneurship is defined as "an enterprise owned and controlled by a woman having a minimum financial interest of 51 percent of capital and giving at least 51 percent of the employment generated in the enterprise to women".

2020 has been a worst pandemic fateful year for all till now. Apart from the enormous health hazard, COVID-19 has also badly hit our economy. A survey conducted by 'Cherie Blair Foundation for Women' has shown that $97 \%$ of women have had their businesses negatively impacted or believe that their business is likely to suffer huge losses because of COVID-19. Women entrepreneurs are mostly doing business in informal sectors that requires close human interaction which would suffer more than sectors like technology and formal sectors where distancing can be practiced through online methodology.

This is the time when women entrepreneurs need more help and guidance to survive in the business field. 


\section{Characteristics of Women Entrepreneur in Informal Sector}

- They had no access for funds from any private or public lending institutions. They depended on friends and informal money lenders for financial matters. This eventually limits their growth because ventures would require capital to expand (ILO, 2006a, b; Government of India, 2001).

- Their venture does not follow any standardized interest rates and opens up these women to severe economic vulnerability (Singh, 2005; Fawzi, 2003; Kapoor, 2007).

- Since the1990s, Micro, Small and Medium Enterprises Development Act, 2006, have promoted several social and economic support schemes for the informal sector, but unfortunately, only minimal benefits have reached the informal entrepreneurs. This is due to lack of access, lack of awareness or cultural constraints that discourage women to go for any social or economic self-support (Singh, 2005; Bhatt, 2006; Chan, 2003).

- Women entrepreneurs in the informal sector were very much confident about their earning potential. They also wanted formal training and sought of support structures to improve their work.

\section{Informal Sector Crisis}

Mostly, Women entrepreneurs in informal sectors prefer to involve in businesses where minimal risk, more profit, less competition can be expected.

Women-owned businesses are particularly vulnerable to shocks, as they are in informal and operate in less-profitable sectors. Government has instructed to follow some forms of social distancing and guidelines that are likely to be in place even after the lockdown. But, the economic activities in most of the informal sectors require close human interaction, Therefore, their businesses are either on the brink of closure or have stagnated. The following are the list of business with low investment of women entrepreneur,

- Parlor services

- Maid services

- Tailoring services

- Handicraft business

- Hotel business

- Day care services

- Tuition services

Providing critical liquidity and other provisions against vulnerable shocks can help to protect women-owned firms from the effects of COVID-19.

\section{Diversifying the Crisis into Opportunities}

- Due to COVID 19 pandemic, women entrepreneurs are in the compulsion to update themselves from offline business mode into online mode to avoid business closure. By adopting diversification strategy, they are able to sustain in the business for a long period of time. There is a list of businesses which require minimum initial investment and less human interaction as they have to be done in online mode.

- Blogging: If writing is their passion, an option for online business for women is writing blogs. Nowadays, many bloggers earn enough money to be financially independent. 
- Graphics \& Design Services: It is one of the home-based online jobs on the internet. Women who are having sound computer knowledge can make money by rendering graphics and design services to the technology-oriented companies

- Data entry: Many companies including KPO, BPO and customer care centres that are looking for data entry workers to feed various kind of data (such as public data, customer support data, manufacturing data, research data etc.) into system.

- Online tutoring: Due to COVID 19 pandemic, schools and colleges are remain closed. So, there are huge opportunities for online tutoring to render education services to the student's countrywide. They just need to enroll themselves into unacademic application and then they will start their career or they can start their own you tube channel to deliver the education services.

- Gardening Business: Women can register as a gardening business seller on Flipkart, Amazon or other marketplaces online.

- Introducing the virtual ordering platform in food business: Most of the women entrepreneur's role themselves in food business are suffering more during this pandemic. They can use the online platform for delivery of foods by enrolling themselves in food delivery app like Zomato, Swiggy etc.

\section{Five Measures to Overcome 'Women Entrepreneur's Crisis' in Informal Sectors}

- In order to enhance more liquidity, Government can provide lines of credit and mesofinancing to overcome such crisis

- Government can provide small incentives and a banking information session to help urban firms for the easy access to financial services

- To address the capital constraints, business plan competitions could be the best tool and also it will encourage investment and risk-bearing capability during the post-crisis recovery

- Government should arrange personal initiative training which teaches women entrepreneurs to be proactive and demonstrate perseverance that may help them to recover from the economic disturbances of COVID 19.

- Proper training to be initiated to guide women who are willing to start new selfemployment livelihood's during COVID 19 recovery phase

\section{Conclusion}

Resources, technology and infrastructure are the major hurdles in the past. However, during this liberating digital age, the spirits of micro-entrepreneurs are incomparably high, as the new-age platforms are serving to innovative concepts that can become a reality. Resources and technology are currently penetrating each nook and corner of the country. New products can discover new markets, while not having the necessity for a middle-man. All in all, the challenges and hurdles exist, however women appear sustained to beat them. It is no wonder that Indian women entrepreneurs are currently more empowered as they are ready to visit new places and courageous to accept new challenges. Women should receive a proper support from their family as well as the government authorities to make them more involved in modern small-scale units. If they are appropriately trained and provided with the sufficient capital despite any pandemic situation like COVID 19, women entrepreneurs in informal sectors can be successful. 


\section{References}

1. Williams, Colin and Gurtoo, Anjula (2011), Evaluating Women Entrepreneurs in the Informal Sector: Some Evidence from India, 16. 351-369. 10.2139/ssrn.2290543, Journal of Developmental Entrepreneurship (JDE).

2. Patgaonkar, Madhavi Sadashiv and Barhat, G.H. (2012), Rural Women Entrepreneurs in the Informal Sector of India (October 1, 2012). Vol. IX, No. 1, pp. 69-79, March 2012, Journal of Developmental Entrepreneurship (JDE).

3. Konstantinos Syriopoulos, Zayed University (2020), The Impact of Covid-19 on Entrepreneurship and SMES, Vol: 26 Issue: 2, Journal of the International Academy for Case Studies. 


\title{
COVID - 19 AND WOMEN IN DEVELOPING COUNTRIES
}

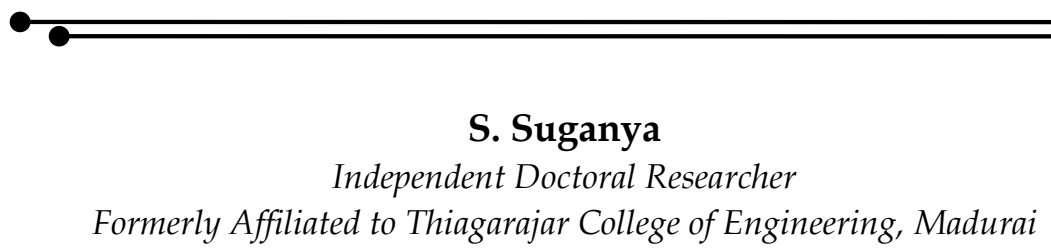

\begin{abstract}
The year 2020, is making threat to the lives around the world with the pandemic COVID-19. The limited gains made in the past decade are at the risk of being rolled back. In each and every sphere, from health to economy, security to social protection, the impact of COVID-19 is aggravated. Many development organizations and research institutions are raising their voice to pay attention on the crisis. In the midst of unprecedented lockdown to protect ourselves from corona virus, the collective strength of women has come into force.
\end{abstract}

Keywords: COVID-19, Unemployment, Violence, Travel restrictions, Health, Pandemic

\section{Introduction}

It is a living document that includes knowledge and happenings all around us during this pandemic scenario. The pandemic is morphing beyond health crisis into socio-economic crisis, causing a serious threat to women's employment. Employers are the backbone of economic growth; the private sector has an important role to play in slowing down the spread of the disease [1]. Many companies are offering flexible working arrangement and paid medical, sick leave and ensured income protection for the frontline workers.

The incentives are not only for serving their employees but also to prevent spreading of the disease. At the same time some non-essential sectors like tourism and hospitality are struggling to stay in business. In united states, the increase in unemployment for about 8.5 million people compared to mid-March and was estimated to be around 13\% on 3 April, 2020 [2].Millions of families are not able to satisfy even basic needs or pay rent and other bills. To be more specific, following are the topics of discussion in this chapter.

- Role of women in diminishing this pandemic situation.

- Increased unpaid care work of women

- Exponential increase in gender based violence

- Economic impacts of women who generally hold insecure jobs and living close to poverty

- Health pandemic make it more difficult for women and girls

This chapter focus on each of these issues, exploring how the lives of women in developing countries is changing with the COVID-19 and outlining some short and long-term recovery efforts that can be considered for implementation.

\section{Meeting the shortfall of requirements}

Women who were once engaged in stitching the school uniforms are now engaged in sewing masks instead. More than 19 million masks have been produced by women across 27 Indian states. One of the earliest Self-help Group (SHG) named "Kudumbashree" with 4.4 
million members with catering experience is now the choice of government to run number of kitchens for delivering food for those in quarantine and the bedridden [3].

Even in areas of high poverty these SHG are helping the district administrative officers closest to the ground in identifying the starving people. Even the people who migrate to work are returning to their family with the dedicated helpline of the SHG. A special orientation and financial incentive is provided by the bank for those women of SHG for distributing the pension and for helping the neediest to the access their accounts.

Alka Upadhyay, additional secretary in India's Ministry of rural development summed up "Women SHGs have risen to this extraordinary challenge with immense courage and dedication [4]. Their services to food insecurity and goods shortages shows how this decentralized structure can be a vital source in the crisis time." "women at the center of development has been an important story in South Asia," said Junaid Ahmad, the world Banks country director in India.

\section{Record breaking participation of women}

The social disruption caused by the virus hit women hard. Majority of nurses, teachers, attendants in flight and workers in service industry are female. The job they possess put them in the front line of the pandemic situation. As the virus closes schools and offices, children and family members stay inside which make women more caretaking. Due to covid-19, travels are restricted and it puts aged relatives at risk, makes women more to do. Also it disproportionately affects the capacity of the women to continue income generating activities given their increased role as caretakers.

\section{Swelling of household water needs:}

In home, women perform a bulk of unpaid care work. Under this strict lockdown, as all the family members are staying at home, and as the government is emphasizing of frequent hand wash, the household water needs have swelled. Thus resulting in making the women spending more time queuing up under the water resource.

\section{Harassment behind closed doors}

Men who are unemployed and struggling to access alcohol and tobacco, are unloading their anger through verbal, physical and sexual attack. This sought of violence is affecting women of all classes [5]. Other responsibilities such as cooking and cleaning have ballooned. Women in Indian families tend to eat last and the least.

Research shows that the health of the women is much more affected than men. The same scenario is visible in other developing countries such as Bangladesh and Zimbabwe. In developing countries, low income family often have only one smart phone, owned by the husband. Lack of accessing private space, makes the women struggle in making calls and seeking help.

Women with less digital access, makes the situation worse, as are cutoff from formal and informal support system. Violence is also in homes similar to battle filed [6]. Violence against women is increasing globally as this pandemic results in limited access to services and reduced support. 
Following are the virtual solutions that are practiced all around:

1. In Canada, COVID response package include $\$ 50$ million CAD to support shelters for women facing sexual harassment.

2. In Australia, $\$ 150 \mathrm{~m}$ AUD is earmarked for family responsive violence.

3. In Mexico a law is being debated to transfer 405 million Mexican pesos to the National Network of shelters.

If we experience violence during COVID-19, do the following:

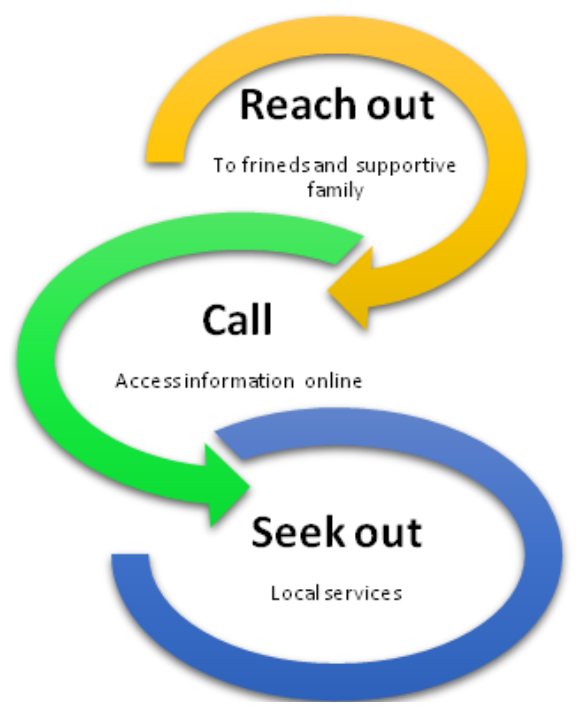

\section{Instability in entire market system}

COVID-19 is obviously a health crisis, it is also a food insecurity and economic crisis. Pandemic has caused trade disruptions as the borders are closed, specifically halting the movement of agricultural goods [7]. Travel challenges and transport restrictions are likely to cause price increase and decrease of the produced goods. Women empowerment in agriculture is noteworthy for the survival and recovery of the situation. They are heavily engaged in agriculture as producers and informal traders. As a result, they will experience a long term impact on the economic prospects because of reduced income and food security.

In Liberia, $85 \%$ of daily market traders are women [8]. The Ebola virus have severely impacted the women's economic security. From the emerging data, the global recession will result in prolonged dip in women's income.

\section{Female labor force participation}

There is aggravated impact of COVID-19 for women already living on the economic margins. India eases its lockdown with fewer employees. The jobs of women are the first to go, as generally they are relegated to menial task within production [9]. Yet their jobs are often undervalued and under paid. The reduced public transit during partial lockdown results in the curtailment of women access to work as they are the one who rely more on buses, trains and share autos for commuting. Also for women using private transport, the problem is quite 
different. Most of the women are unable to work remotely [10]. They require additional care and support for their children or older family members in home as they leave for office.

\section{Health Impacts}

Women and girls have unique health needs, but due to pandemic situation it is less likely to access health centers. Also maternal and reproductive health care requires frequent consultation with doctors, but due to COVID-19, they lose regular access. It has been found that the mask designed with 'default man' size, makes women to get more exposed [11]. Particular attention need to be paid for the older women, gender based violence survivors, postnatal care, delivery services and newborn care.

\section{School closures}

Millions of teachers and students are staying in home as the COVID-19 school closure expand. This could also lead to millions of girls to drop out of school before completing their education. This mainly occurs for the girls living in poverty and also for girls with disabilities. Girls living in rural area are at particular risk of dropping out and not returning to school even after the crisis is over.

\section{Obligations}

COVID-19 is not only a health issue, but also a test to our human spirit. To clear the test, following are some of the prioritized measures to be taken:

- In recovery effort, women employment must become a priority.

- Specifically, for low income women, skills should be scaled up and enhancing the digital access need to be targeted.

- Ensure psychosocial support for women and girls

- Introducing new measures that can be implemented in low cost such as eliminating the electricity bill for poor consumer.

- Alleviate the tax burden on women owned businesses.

- Continued attention for the new born and delivery services should be ensured even under any crisis circumstances

- Expanding the child care support.

- Take the opportunity to start new local business, especially with women as they are affected by the crisis.

- Communicate to women to acquire new skills that will be required for post-COVID-19 survival.

- Donate protective equipment, food and sanitizers.

- Offer a short moratorium on expenses like rent.

\section{Conclusion}

Increase in violence is happening at the same time services are compromised, which is not appreciable. The gender impacts of the pandemic need to be addresses by including the women at the heat of COVID-19 responses. Letting women and girls at the center of economy, will drive good and more sustainable environment for all. This will help us to place back our foot to achieve Sustainable Developmental Goals. Henceforth, the pandemic situation has put spotlight on societies reliance on women. 


\section{References}

1. UN Women, In Focus: Gender equality matters in COVID-19 response, 2020, http://www.unwomen.org/en/news/in-focus-gender-equality-in-Covid-19 response.

2. United-Nations Secretary-General Policy Brief, "The impact of COVID-19 on women and girls", 3 April 2020. Available at:

http://www.unwomen.org/media/headquarters/attachments/sections/library/

Publications/2020/04/family-friendly-policies-and-other-good-workplace-practicesin-the-context-of-COVID-19.

3. OECD, Small business, Job Creation and Growth.

http://www.oecd.org/cfe/smes/2090740.pdf.

4. Lockdown around the world bring rise in domestic violence" http://www.theguardian.com/society/2020mar/28/lockdown-world-rise-domesticviolence, accessed 3rd August 2020.

5. European Union Agency for Fundamental Rights (2014): Violence against women an EU-wide survey.

6. http://undocs.org/E/CN.6/2020/3

7. “CORONAVIRUS. I'm in lockdown with my abuser” http://www.bbc.com/news/world52063755, accessed 3rd August 2020.

8. Pandemic profiteering-How criminal exploit the Covid-19 crisis, March 2020, Europol.

9. http://www.theguardian.com/world/2020/apr/02/coronavirus-lockdown-raisesrisk-of-online-child-abuse-charity-says.

10. http://www.reuters.com/article/US-women-rights-cyberflashing-trfnidUSKBN2153HG.

11. http://www.sddirect.org.uk/media/1881/vawg-helpdesk-284-covid-and-vawg.pdf. 


\title{
THE CARE ECONOMY FOR WOMEN: \\ COVID-19 TRANSFORMATIVE POLICY
}

\author{
Dr. Bhagyalakshmi Rajaram \\ Associate Professor, Department of Management of Studies \\ PSNA College of Engineering and Technology, Dindigul
}

\begin{abstract}
The corona virus pandemic episode wreaked a catastrophic impact on patients and mental health of the people. The year 2019 brought more insights into the social, political and economic movement all over the world. Households especially women are not exceptional to this effect, since they face high stress to cope with caring and sharing of available resources for family and infected patients if any in their family. The novel disease made the household women to frontline Health Care Workers (HCWs) often women are more intellectual and responsible person in the society delivering continuous service. Concurrent to this, research in this area has repeatedly proven that exhibiting empathy along with fathoming of a family and patient's necessities, opinion or perception and considerations will enrich the experience of family and patient. Subsequently, proper care and gender equality may lead to quality in clinical results and productivity, because of augmented patient coordination to doctor's treatment and health plans. This manuscript focuses on economic distress that would augment the prevailing inequalities most particularly the gender discrimination for care economy. Subsequently, elaborates the women's empowerment along with gender equality on ameliorating health care, procurement cum distribution of Personal Protective Equipments (PPEs), abating crisis through innovative management strategies and external factors impact. Thereby providing valuable suggestions for major COVID-19 affected countries to adopt a gender oriented policy to overcome crisis based on two predominant variables: introvert verses extrovert women transformative policy. The social implication of this chapter will be to mitigate panic and negativity of corona virus (wreaked by lockdown, social distancing, and closure of borders) in family with women as the nodal point of crisis management.
\end{abstract}

Keywords: Introvert, Extrovert, transformative policy, crisis management, care economy, gender equality.

\section{Background of the Study}

In the outset both men and women are equally vulnerable to corona virus COVID-19. However the mortality rate projected high for men compared to women due to tremendous supply of Angiotensin-Converting Enzyme 2 (ACE2) in their blood that weakens healthy cells like a piece of cake. This formidable evident shows how culture, customs/traditions, social norms, attitude and behavior commiserate gender disparity. Moreover, men are exposed to dreadful habits to list a few smoking, consuming alcohol and so on leading to fatal diseases. Even though $21^{\text {st }}$ century girls and women claim equality in those mischievous habits they still hold high immune system unlike men. In addition, the predicted survey on gender contribution in UK shows about $77 \%$ of the National Health Service (NHS) community and care economy workforces is women. While only $5 \%$ of the women elected as top most authorities in large corporate or Multinational Companies (MNCs) when compared to men who backed up 70\% CEO and board of directors position in the world. Furthermore, women at home face psychological mishaps illuminated by negative treatment and abuse by men who 
lost their jobs, unpaid, quarantined and work from home perturbing behavior knowingly or unknowingly. Subjectively, a brief elaboration on women transformative policies articulating access to COVID-19 facilities, targeting challenges and affirmative action for women towards inclusion is being presented in this chapter. The framework of this chapter lineage from the two personality types of women transformation policy to an overview of care rendered economically by women in various field.

\section{Introduction}

The end of 2019 and the beginning of 2020 the world was startled by the mortality rate due to the outbreak of corona virus descended from Wuhan, China. The evolving pandemic crisis rampage hither and thither capsized the lives of women in an economy. Despite the inactive personal life which is being frozen or shriveled by plethora of reasons like quarantine, lock down, social distancing, out casting, unemployment and lay down, women all over the world face potential risk and returns non monetary or financial-social wellbeing. Paradoxically, when it comes to women empowerment the sayings "In the middle of the difficulties lies the opportunity" goes well with women in this COVID-19 disaster. May it be either household chores to social service or agriculture to industry women are globally remarkable for their productivity being a major contributor as nearly one in three workforces are women workers. This COVID-19 unfolds and brought opportunity to initiate equity and gender equality thereby accelerating women empowerment. A real time case record for this includes Jordan's innovative technology application for safeguarding women in which two women Amal Al Mahayrah and Hadeel Dabiben support Jordanian girls and women via mobile with a 24 hrs hotline and a innovative Blockchain Cash Disbursement System (BCDS) in which each refugees account is channelized to a supermarket established by World Food Programme enabling them a hassle free affordability of groceries and essential supplies.

\section{World's miserable women}

The United Nations corona virus quote says "What the world needs now is solidarity. With solidarity we can defeat the virus and build a better world." Even it is a homogenous society woman faces various kind of problems during this pandemic, and if such is the case, in our universe a multi part of various races, languages and cultures live in different countries. Within the society they have more families bound by inter racial and international marriages too, making the problem more complicated. As such, within the society the issues faced by woman during this pandemic have an extra edge as supposed to their counter parts elsewhere. The clear classifications of women who are affected y the pandemic in various levels worldwide are represented in figure 1.1. COVID-19 - Worlds' miserable women. 


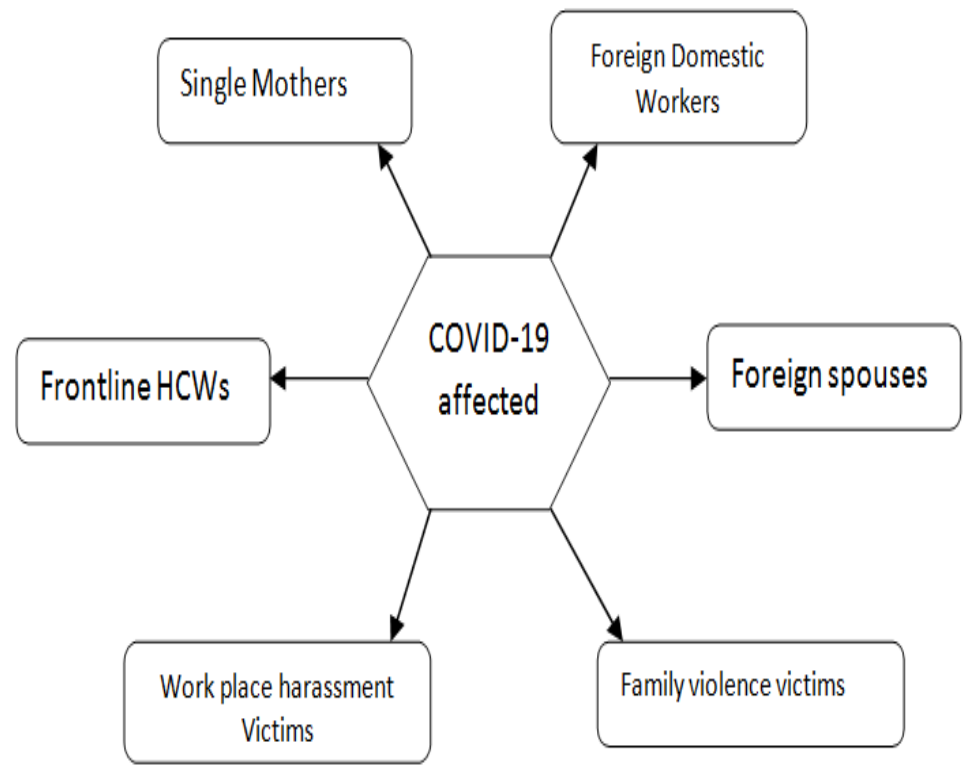

Figure 1 - COVID-19 - Worlds' Miserable Women

The represented people are those who form the sizeable portion of the women community who face the issues more strongly than the other part of the world.

Single Mothers: Single income family run by the single income mothers are one of the most affected during Covid-19. They may attribute to different kinds such as local women, women who are married to foreign spouses who are very well and polite previously, then there are other kinds of single mother who themselves hail from broken families and who had become teenage mother earlier, also single mothers who were homemakers once and who's spouses gone in search of other women's and left without any financial support. The low income women are highly affected since several people lost their jobs that involve house visit people with more contact and so on. On top of this they have to mind their children alone with no support as many child care centers have issued stringent guidelines to help the children and when kids have even their usual bouts of cold, cough or periodic fever now they have to be kept at home with their single mothers who also have to struggle to provide food for that child without any source of income. World must provide some benefits to such categories like for example Support Housing and Enablement's (SHE) project shelter provided by Aware, Singapore has been very supportive to their single mother.

Foreign domestic mothers: Foreign domestic mothers on the other hand face a unique problem like they are not able to use their annual leave to visit their home countries as there is COVID-19 threat. The foreign domestic mothers working in other countries are actually living workers; they live in their employer's home or offered quarters. Employers provide them with food, shelter, medical benefits what so ever. But now the real problems of foreign domestic mothers are quiet miserable. For example, US or Singapore mainly sources its foreign domestic mothers from Philippians, China, India, Indonesia, Myanmar and Italy. They are trapped in this COVID-19, these workers hailing from these countries they are actually due for their hard 
earned vacation now. Unfortunately, they are unable to move because there were no flights, even if they get emergency flight and leave upon landing in their home countries they are supposed to undergo a quarantine check for 14 days. After that they have at most 3 to 4 days to visit their family. And if they is ever a flight flew back to their work place again they have to undergo quarantine. Therefore paid leave like this ends in vain. Furthermore, if they move the renewable of passes issued by the Government ends in devastating effort. The government restrictions to protect them from COVID-19 banned their movement and congregational even in local or within the region. Hence, they can't spend their week days too, discontinue meeting their peer group or social group uplift their worries. Of course, foreign domestic workers have their private space even though they are working but now everything has been robbed off. They will be denied of all this now. The domestic workers under normal circumstances would be doing their household chores, minding their children, cooking and picking their kid back from school. Removal of the window of respite to these foreign domestic workers might have long-term psychological repercussions on them affecting their relationship with the employer and her family. This actually changes the very mechanics they are living; it creates them real stress such as looking after immune deficiency elderly and children. Many employers have also reportedly developed a never-before found sense of empathy towards these live-in Foreign Domestic Workers due to their current shared woes. They do take enough care of their workers to ensure that they are given protective shields, hand-sanitizers and gloves. But their emotional needs are still to be addressed at large.

Foreign spouses: Foreign spouses of local citizens and Permanent Residents (PR) will be affected due to this pandemic tremendously due to family restrictions, travel restriction, lack of flight has created a serious emotional crisis for this spouses who are usually on a long term visit pass. Some of this children risk separation from their nonresident parents who are now bought from reentering the country unless they are work pass holder providing healthcare and transport. Since March 23, 2020 parents who are holding short term visit cannot enter one country from other country. Just imagine the fight of kids, one parent stay in domestic country and other parent at other country. They are physically separated, without anticipation leading to pathetic conditions. Foreign spouses benefit from government subsidies and rates so government does support them in necessities but they can't do anything with travel. Moreover, they may not able to move their children to the country of origin either due to pandemic condition. They simply have to wait and face the challenges of traveling through emergency flight. They are in a position to bear whole medical expenses if they travel amidst of travel ban. Based on existing research women foreign spouses perform plethora of frontline jobs in the job market like retail, food and beverages, homecare, receptionist. Now, this work pushes them with more of interaction and risk of COVID-19 infection given them of close interaction with customers and clients. Unfortunately, there is another downside for these pandemic affected women spouses, during this pandemic most of the establishment were closed for a prolonged period, many of these women lost their jobs. It is not going to come back to them in the near future. In some extreme cases this has become inner cause for future divorces. Not that there was no reasons for divorces other than financial causes, but these are current excuses enough to trigger more number of divorces leaving most of the children caught with mom or dad without knowing what is happening around them, whatever be the 
age they are already shocked. Rather than sensationalizing the issue, just fathom the cross sectional issues faced during this COVID-19 outbreak.

Family violence victims: Family violence victims are the other type facing drastic impact due to COVID-19. Since all the families are cooked up in limited spaces, lack of personal spaces and availability of limited resources are the challenges faced by entire family. Women are extremely facing trouble who actually recharge while coming from work and engage themselves in domestic works is now finding it much difficult to cope up the situation. At least now men might have realized the paradox. Both the partners going away for work and meeting only for restricted hours is common nowadays. People all over the world live in extended family and joint family for social convenience such as child needs and elderly care. Thus women who are working and also shouldering their domestic responsibilities facing the problem of automatic demand for more foods, cooking making of more delicacies and its short of vacations. Many people think why they can't do better, extra snacks crispy and delicious. Just because she is physically sitting in her home office at home during day time all this demand is imposed on her, she just need to utilize her break hours and then put something in so that the entire family don't buffer her during her working hours. Another problem perforating working women is sending their kids to their parents place or in-laws place is now not possible anymore. Also, they can't order foods online. On top of the demanding jobs nurses, health care workers can't be exempted from work, in India and other countries they are asked to vacate their vacations. In addition to this, the issue of cyber space usage by all family members. The worst condition is low income family still abuse women counterpart on depression. The husbands demand from women to fulfill the obligation as a whole, women suppress their emotion for the shack of children. Social separation blows the situation since there is no way to release the stress.

Work place victims: Abusive and insult language send to them from their colleagues, they take the liberty to call them at any time. Even at week end they receive calls regarding work prolonging the conversation and fix a deadline. They supposed to report fast with comments. For example teaching women need to comment for 200 to 300 words for each and every assignment submitted by their student during this COVID-19. Everything is happening at one circumstance all at once like using the Google meet, digital transformation.

Women as Health Care Workers (HCWs): Contrary to what has been discussed so far, approximately $75 \%$ of women dedicated as HCWs in world's health services. Of course it is obvious that nursing is a job exclusive tailor made for women which is a universally accepted norm. About 9 out of 10 frontline health workers are women not men. Thus proving, women in COVID-19 pandemic situation are the most affected variable in the society compared to men. In fact, they are overburdened with care economy for example they could not replace their service or withdraw from their service at times of peak crisis. Though, health care jobs provide incomes for their family, protecting their society will be the primary responsibility. Humanity concern overcomes the materialistic concern in the mindset of women in health care services. As an illustration, international studies in this area such as Carol Gilligan's theory related to moral development in women suggest that women's relationship with family and society is 
entrusted by caring nature which is inculcated by birth. Contradictory to this phenomenon COVID-19 capsized family's responsibility collectively in the hands of men and the society's responsibility is in the hands of women who are versatile to exquisite care and nurturing victims of corona virus. It is inevitable that the world has witnessed how women HCWs exuberant service even at this excruciating time of COVID-19. Therefore, women always remain as the crux of society with equality rights they must be given priority in decision making and policy framing. Beyond, the threat of communicable diseases like Ebola, Rabies, Hepatitis A, corona virus as listed by WHO as well as Alameda County Public Health Department (ACPHD), the universe seldom depend on money or men, but wholly depend on women. Hence, the world must respect women and protect their rights at any cost.

\section{Social implications and Conclusion}

Our actions are equal and more vulnerable to women at home, what a person is intending to do is reflected in her actions. Therefore, they serve as the nodal point where integrity in relationship, commitment, and private interests lies. However, in home, corporate, health care households and their actions is an amicable tool in the hands of health service providers such as doctors, patients and HCWs who experience dreadful effect, aloof, petrified and astonished. As such, it is amicable to discuss and analyze the comparative effect of COVID19 on the performance of women Vs men during quarantine. Today, most of women are working and family dependent on them socially and economically. Therefore, nowadays the role of women who are single mother or foreign spouses are contentious at times of pandemic episode that shakes the whole world. COVID-19 transformed the way women are participating in work and home, the commitments varies accordingly the attitude and responsibilities are vulnerable to changes. The concept of work from home can be made simple and hassle free in an environment with an admirable atmosphere for women of various categories. The sense of freedom and underlining unrestricted sociability may rejuvenate women to operate remotely resulting in a high productivity. It's obvious that women may in common have no obstacles or negativity towards working in aloof. Absolutely, women seek to be quiet, calm, reserved, seldom silent observer in a group unlike the men who seek center of attraction and rapid conversation. In fact, family women prefer to be isolated from their co-workers. As a repercussion one can fathom that women cannot cope up with COVID19 pandemic situation even though they choose righteous to work from home. With their personality traits they may suffer or feel suffocated without being able to work in a group or outgoing and talkative. Nevertheless, there are myriads of personality traits that an organization need to consider while gauging the women's mindset to work from home, but the most conspicuous is rooted in high degree of emotional stability. At this juncture, as rightly suggested by Goleman, Emotional stability set attainment through Self-Awareness, Self-Regulation, Motivation, Empathy and Social Skills must be renowned by women. Nevertheless, Government has to come out with measures to protect and set back the scenario back to pre COVID-19. This means getting help from women organizations, planning for equality and equity, finally, creating new care economy through transformation of unpaid care work. 


\section{References}

1. Davies, S.E. \& Bennett, B. (2016). A Gendered Human Rights Analysis of Ebla and Zika: locating gender in global health emergencies, International Affairs, 82(5), 1041-1060. https://academic.oup.com/ia/artical/92/5/1041/2688120

2. Mazzucato, M. (2020, marzo 18) The Covid-19 crisis is a chance to do capitalism differently. The Guardian, Opinion: Coronavirus outbreak. Retrieve from https://www.theguardian.com/commentisfree/2020/mar/18/the-covid-19-crisis-isa-chance-to-do-capitalism-differently

3. OIT (2020, marzo 18) COVID-19 and the world of work: Impact and policy responses. Retrieved from

https://www.ilo.org/wcmsp5/groups/public/-dgreports/dcomm/documents/briefingnote/wcms_738753.pdf

4. UNCTAD (2020). The coronavirus shock: a story of another global crisis foretold and what policy makers should be doing about it. Trade and Development Report Update. Retrieved from https://unctad.org/en/PublicationsLibrary/gds_tdr2019_update_coronavirus.pdf.

5. Wenham, C., Smith, J. \& Morgan, R. (2020). COVID-19: the gendered impacts of the outbreak, The Lancet, 395(10227), 846-848. Retrieved from https://ww.thelancet.com/journals/lancet/article/PIIS0140-6736(20)305262/fulltext 


\title{
SELF HELP GROUP - A FIREARM AGAINST PANDEMIC

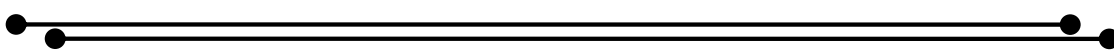

\author{
Dr. R. Radhika Devi \\ Director i/c, Women's Studies Centre \\ Madurai Kamaraj University, Madurai
}

\section{Introduction}

The Self-Help Group development programs have been aimed for the empowerment of women in the socio-economic point of view. Reports indicate that the main form of a self-help group is the schemes of savings and microcredit which have flourished the lives of women who are in the poverty line by creating progressive factors such as social status and empowerment

The involvement of women in pecuniary activities is considered to be a significant factor in the economic and social empowerment characteristics of women. Appropriately identifying the significance and the participation of women in the growth and development, In India, both the Governments have taken up the subject of women empowerment as one of the main programs to eradicate poverty and many socioeconomic concerns. With over 700 million women living in poverty around the world, micro-finance and enterprise promotion programs through SHGs have seen as an essential tool for poverty alleviation. Women SHGs have contributed significantly to the economic development of the country. In brief, SHGs facilitate the coming together of women as entrepreneurs to ensure an additional income. And, in the process, it creates a heightened sense of awareness and confidence in their role by contributing to the family income and ultimately to the rural economy.

The Grameen Bank of Bangladesh was the original idea that was modelled and supported by the NABARD and it took nearly two eras for the perception to be integrated with the national-level program. Swaran Jayanthi Gram Swarozgar Yojana came into operation in the year 1999. In the year 2011, the SGSY was incorporated in the NRLM and then it was renamed as Deendayal Antyodaya Yojana National Rural Livelihood Mission. The mission focused on the creation of economic opportunities for the supportable source of revenue. The self-help group was the main core concept of the mission and it's one of the prime poverty eradication programs in the world.

To empower the rural women, Self-help group have acted as a vital tool through ability developing in the agricultural and other allied activities. The main purpose of this program is to make women earn their incomes independently through various activities by skill-building and getting support from the federation for financing and other related trade activities. The SHG has acted as a facilitator of the self- confidence and social harmony of women.

The Self-help group is not only the finance function activities but also it acts as the source of the aggregate actions, cordial relationship and responsiveness. This program used to act as the source of the knowledge and wisdom by creating the discussion and informal conversation in the group. Women frequently engage in this discussion so that they can strengthen their bonding and social relationship. The group also focuses on the training by a various 
organisation like CSOs (Civil Society Organisations) and create the awareness on the women related problems such as gender equality, women health, violence, child abuse and the like.

In India, Self-help group over the past two eras has evolved into one of the world's major organisation to overcome the poverty from small savings and credit groups that pursed for the empowerment of the women. At present in India, sixty-seven million women are members of six million Self-help Groups.

\section{Pandemic Consequences for Women}

Generally, women are considered to be the most caregivers in various places like home, hospitals, schools and societies, this activity has led them to face the risk of COVID.

In the rural area, since there was a shortage in the labour force due to the shrinkage of the migrant labour force women's participation in the farms has raised in many regions. For example in our country during the current year, the period of harvest falls in the months of March-April, due to this pandemic many migrant workers have gone back to their homes due to lockdown this situation has created high agricultural wages for women in the short-run. Thus, women are more demanded both within and outside the household in rural areas.

There are a high percentage of nuclear families in urban areas, women in this area have to maintain the family by being in the residence to look after the children, the sick family members and there are other reasons such as loss of employment, income and the like. During this pandemic situation, everything is going work from home, if they work from home continues it creates more job opportunities for the women those who prefer home-based work.

Likewise, in several countries, female participation in the labour market is frequently in the form of provisional labour. In total population, women constitute less than forty per cent of the total employment. In many countries, there is more restriction which will create more hindrances to women who mainly depend on their income that they earn on a day-to-day basis.

\section{Self Help Group - A Weapon against COVID}

This COVID emergency and the consequential lockdown posture distinctive challenges for women's Self-help groups, however, earlier proof recommends that women's SHG may afford its participants with the mechanisms to cope with emergencies.

The Lockdowns imposed by the Government are mainly stimulating for women's Self-help groups since not quite all women's groups meet materially. After unlock, social distancing rules may act as abound the ability of women's group members to meet. In meanwhile, proof suggests that the public, social, and fiscal capital created through self-help groups may empower its group associates to diminish the difficulties of negative financial and well-being.

Moreover, emerging sign advocates that scaled-up Self-help groups and other groups have shaped various governance structures which make these SHG in a good position to subsidise to the execution of social safety grids. Self-help Groups which have more members act as sustenance to the public health prevention measures. Possibly for these causes, in India, Government and Non-Government institutions with an emphasis on routing subsidy and public response initiatives through self-help and savings groups to reduce the undesirable economic consequences of the lockdown. 
At present in this pandemic, there is no activities of Self-help groups have been taken place. No meetings, no savings activities, no loan, no recovery. In June, our country rural areas have entered in a new sowing period. At this time women have prioritised their livelihoods which have affected the regularity of all self-help group activities. In this COVID group members neither have no time to meet nor to solve their problems.

This situation is a significant phase that is likely to get weakened but this can be evaded through various forms of online communications and more user-friendly and outreach to women by gender victors which include the leader of the groups, resources persons from various communities and the like. For some activities, the groups have started using whatsapp as the mode of communication. Usage of these communication tools have changed the nature of the meetings conducted by the group members and allows the flow of accurate information. Though communication in the online mode may not be the same as the weekly SHG meetings, these weekly meetings should be conducted with social distancing policies as these meeting not only a way for savings but also it guarantees security and support.

Even though the latest information focus on the role of Self-Help groups during the endemic period, there is almost no proof of the impact of COVID on the operation and efficiency of SH groups. Scholars have only in recent times started concentrating on the gendered influences of the pandemic, and strategy briefs thus far have mainly centred on the influence of interferences with women under typical situations, perhaps since the emergency reaction has mainly targeted direct community health and social protection responses.

In our country, battle in contradiction of the coronavirus requires all investors to take responsibility and give support. One among these corona warriors is the women operated Selfhelp group which have developed as active forerunners, accomplish the last-mile and guaranteeing a speedy recovery and socio-economic security to the country's most susceptible.

\section{As Community Kitchens}

The Government of India has joined with Self-help groups in many states to promote communal based reactions to the COVID and the lockdowns. For instance, SHGs having more strong networks with the state government like Bihar, Kerala, Jharkhand, Madhya Pradesh, Odisha and, Tirupur in these states more than twenty thousand community kitchens were started operating. In Kerala state, the Kudumbashree is one of India's earliest community network of women with more than four million members and serving many years in the catering field. For this reason, the government support them to run several kitchens. With their nature of task taker, these SHGs have intensely increased their activities and now operating 1300 kitchens throughout the state and these women also deliver the foods to needy and bedridden people in quarantine.

Women's Self-help groups are also providing and delivering the required items such as items distributed at PDS, foods, and the like at the doorstep of the needy people. These activities are undertaken by Mission Shakti in the state of Odisha. SHGs also have been organizing and producing personal protective and hygiene materials such as masks. The members of Self-help groups have produced millions of masks and litres of sanitizers. 


\section{As Manufacturer of face masks}

The kindliness and awareness created by women's groups amidst the pandemic emergency at the communal level are extremely praiseworthy. Among the developing concerns of a lack of face masks, Self-help groups operating in more than 500 districts in all the states came forward swiftly and have already mass-produced over 19 million face masks for delivery. In the state of Odisha, for example, the women who were engaged in the stitching the uniforms of school children are now stitching masks instead of uniforms. In this pandemic months these women groups have produced more than one million masks and this, in turn, have helped the works of various departments such as police, health and the like. Other than mask producing they have prepared one lakh litres of sanitizers and more than 50,000 litres of hand wash. The production is decentralized and they have been benefiting the vast population spread.

Self- help groups in many states of our county have involved themselves in distributing the items of PDS, foods to the poor and helpless families. They also extend their hands in producing required items for the frontline workers.

\section{As Generator Awareness}

The Self-help group system in the states offers a recognised structure that can restate the accurate communications to participants and communal to create responsiveness on social distancing, the practice of face masks, suggested practices, quarantine and the like. Group undertakes are doing an energetic role in safeguarding and ensuring that publics maintain social distancing in bazaars, ration shops and the like. In Kerala state alone, about three lakh Whatsup groups with twenty-two lakh group participants have been set up to train its members and in turn, these trained members train their families and others about provisions of the government regarding COVID.

\section{As Financial Advisor}

During this lockdown period obtaining finance is a serious issue to sustain themselves, the self-help group members also engage themselves as bank correspondents that have emerged as an important role. In India self-help groups members involve as Bank Sakhi and help to deliver the financial relief packages at home for the rural poor people those who are facing the socio-economic sorrow, retirees and those who are under the Mahatma Gandhi National Rural Employment Guarantee Act. The members as Bank Sakhi are given a special orientation by the banks and they also provide them with the financial assistance to enable them to work during the lockdown period. The group members can overcome the digital distribute by operative cash dealings through e-banking, they can encounter their peers through digital media without gathering by the person; they can maintain their accounts in e-Shakti.

\section{As Online trader}

Self-help group members can trade their products through various online portals like Amazon, Flipkart, and the like, by selling through this they can earn more income and repay their bank debts on time. The group members can be instructed through online teaching in areas of monetary, digital literacy, group dynamics, distribution management, risk 
management, and morals. Moreover, the members who have borrowed should be trained in terms of self-confidence to excel in income-generating events by acceptable technology.

\section{Conclusion}

The Self-Help groups are a consistent low-level establishment, informally sensitive, with a great level of poverty co-ordination because of their structure, skilled of scaling up or familiarising swiftly through associating and re-forming procedure. These groups make them enormously useful in times of natural calamities, mainly for spreading socially essential communications, including well-being, diet and education.

The assistances of these groups in tackling the COVID pandemic must be accredited, one must endure to support them, and reproduce the model across the country. The SHGs must be given a necessary fiscal and societal empowerment. Everyone must identify that current emergency response and the social and economic protection of the most susceptible is critically reliant on institutions like Self-help groups. These groups will possibly show themselves to be precious in ensuring literacy; hygiene and cleanliness; health care; nutrition to infant and mother; vaccinations and injections and social hygiene. There is a vital necessity to invest in these groups and to deliberate immediate savings in the panchayats to get the best synergistic impression. 


\title{
THE PERCEIVED STRESS OF WOMEN AS VICTIMS OR WARRIORS OF COVID-19 PANDEMIC
}

\author{
Dr. B. Winmayil \\ Assistant Professor of English \\ V.V. Vanniaperumal College for Women, Virudhunagar
}

\begin{abstract}
Time immemorial women across the globe have been under an unprecedented impact of multiple issues and of the worse time ever they have been bearing the brunt of COVID-19 pandemic breakout. There is an urgent need to analyse the sources of their hardships that may inflict higher level stress-based health problems. It is well proved in medical history that stress constitutes a risk factor for the development of any disease. This study aims at enumerating the stress factors at different spheres of life that threaten women's physical and mental health and impede their resilient power. A questionnaire based on Perceived Stress Scale was responded by 148 women of different lifestyle, location and workplace. Individual's stress level and the type of stress they have been undergoing were analysed using weighted average method. The results indicate that the present scenario inflict higher psychological and physical disturbances and hence women are more affected by the internal stressors than the external during this Pandemic. This research concludes that women who are resilient could overcome internal stressors and empower themselves as selfefficacious to handle external issues.
\end{abstract}

Keywords: Stressors, Women, Pandemic Perceived Stress, Psychology, Self-efficacy, Resilience.

\section{Introduction}

The outbreak of Novel Coronavirus Disease COVID-19 in December 2019 has taken away not only the lives but also the hope of the entire human race, however fighting for survival has been the core idea of its existence on this Earth from the time memorial. Several studies have remarked that women have stronger immune system than men and hence COVID-19 is hitting men more than women. Women have been enduring numerous plague-like evils across the globe independent of their age, class, gender and race. They have been cultivating a power to strive hard, fight against victimisation as a warrior, emancipate and emerge as an empowered entity of the society. This self-efficacy of women keeps them excel in academics, business, leadership, and what not on earth to conquer for her. They gain resisting power that could increase their survival of the fittest. Moreover, they are the fulcrum of all Indian families since they take care of harmony, relationships, health and wealth of the home. Hence it is essential to ensure the safety, security and well-being of women and to scrutinise the factors that may entail danger to their resilience.

\section{Objectives}

All who were born as women have an innate skill to tackle the challenges they confront at the time of crisis. Apart from patriarchy, there are some major influences which could disturb the family life, attitude, health and peace of women. Among those issues some are external challenges for which a woman has to either endure or protest and the rest are internal elements which are universal making her combat with her own self. Marcelle Pick defines the 
two types of stressors as, external stress comes from things outside you that you can't control, while internal stress comes from within. So major life events, like the death of a loved one, marriage, or a big promotion; work deadlines; social encounters; unexpected events, like a major medical expense; or environmental factors like noise, smells, and temperature are all external. Your hopes and fears, expectations, beliefs and uncertainty can all be sources of internal stress. (n.p.)

This study attempts to examine the differential impact of internal and external factors on women during this Pandemic crisis. To comprehend the severity of impact of these influences, a survey was conducted on 148 women of all age groups and working sectors including students and homemakers.

\section{Literature Review}

Stress is one's psychological reaction to an external change that requires a physical response. Perceived stress is an estimate of an individual's feelings and thoughts responding to a particular critical event. It measures the degree of stress in a certain period and also one's ability to cope with a specific crisis. This COVID-19 lockdown keeps women of either employed or unemployed, poor or rich, and literate or illiterate highly stressful. The higher the perceived stress level a woman has, lower her self- efficacy level will be. "Bandura stated that people with high efficacy beliefs persisted with the task in the face of difficulty and achieved higher results with lower levels of stress" (qtd. in Vaezi 1168). Marcelle Pick reported that external stress leads to internal stress. Canadian's Women Foundation found that women face a heightened risk of violence at home with COVID-19 isolation measures, whether it takes the form of emotional, physical or sexual abuse. Andrea Gunraj opined that gendered impacts of coronavirus isn't a fringe issue.

Lazarus and Folkman found that stress not only triggers negative emotional responses but keeps the individuals interact with their environment. In addition, stress can impact individuals' well-being or functioning negatively only when individuals perceive the situation as stressful and their ability is ineffectual to handle external issues. (Berjot n.p.) The above mentioned studies reinforced that there is a link between external issues and stressors. When there is a prolonged stress, it will affect the physical health of women. This uncertain future, limited space and tough time have left women lonely and stressful. Their issues as well as their stresses are mostly untold and uncounted. As it is not a fringe issue, it is mandatory to scrutinise the stress level of women who deal with the circumstances directly.

\section{Research Hypothesis}

The Pandemic insists the maintenance of hygiene and physical health to mitigate the spread of fatal coronavirus. Yet, the healthcare of people gets affected giving a hike to the casualty worldwide. This dreadful crisis has intensified the communication of fear, anxiety, loneliness, trauma, obsession, disorder and other countless or ineffable mental disruptions. The analysis of current scenario predicts women getting vulnerable to the psychological trauma due to either the combat, the loss or the failure they encounter. When the entire human race is getting ready to recover from the massive loss imposed by the miniscule virus, among all sorts of resilience, it is a must for any woman to have stress resilience coping with the Pandemic. Therefore, this crucial statement raises some research questions: What are the 
issues that impede the resilience of women? Are women restricted psychologically, physically, domestically or financially? Which of the factors highly inflict stress on women during this Pandemic outbreak. The following hypotheses were framed to probe into the collected data.

(Null) $\mathrm{H}_{1}$ : There is no significant difference between the impact of internal stressors and external stress factors on women during COVID-19 Pandemic Lockdown. $\mathrm{\Psi}_{1}-\mathrm{\Psi}_{2}<=0$

(Alternative) $\mathrm{H}_{2}$ : There is a significant difference between the impact of internal stressors and external stress factors on women during COVID-19 Pandemic Lockdown. $\mathrm{U}_{1}-\mathrm{U}_{2}>0$

$\mathrm{U}_{1}$ - sum of the weighted average of internal stressors ; $\mathrm{Ч}_{2}$ - sum of the weighted average of external stressors

\section{Methodology}

The questionnaire collected the demographic details including name, age, gender, educational qualification, location and occupation from the participants of the survey. The stress factors were divided into four categories based on their sources : Financial, Familial, Physical and Psychological. They were measured by the Perceived Stress Scale, an instrument measuring the perception of stress. Participants were asked to select how frequently they experienced each item during the lockdown period on a 5-point Likert scale ranging from 0 (never) to 4 (maximum). Each category has a 10-item version that has been used in studies investigating financial crisis, familial issues, physical torment and psychological trauma among women. Total scores are obtained by summing all ratings of 10 items, with higher scores indicating greater levels of perceived stress. The weighted average of each 10 -item was calculated to compare the influence of the internal or external issues as stressors on women.

\section{Data Analysis and Findings}

Stress Management helps one to develop positive attitude. The stressors are invisible giving one an inexpressible pain unravelling the real challenges of life and mind. Since the stress caused by the issues such as Physical Torment - heavy workload, sickness, fatigue, and lack of healthy food - and Psychological Trauma - loneliness, depression, insomnia, anxiety over health and insecurity- especially during this Pandemic crisis, affect the internal organs of the body and inner peace of women, they are termed as Internal Stressors. Emotional and physiological responses to these stress factors obviously disturb an individual's internal milieu. Moreover, the chronic psychological stress that are left unchecked entails health problems. The Familial issues - patriarchal family setup, marital conflicts, family burdens, domestic violence and lack of social support - and Financial Crises - underpaid job, career uncertainty, medical expenses, loan overdue and lack of savings - are the disturbances from the outside contexts. COVID-19 curfew made both men and women financially unsecured and emotionally alienated. The fiscal hardships and family problems are termed External Stressors that hit a woman socially and economically dependent and thereby confines her space. Here, table 1 and table 2 tabulate the external and internal factors respectively taken for study to analyse the level of stress caused by them. 
Table 1: Descriptive Statistics of 20-item External Stressors

\begin{tabular}{|c|c|c|c|c|c|c|c|c|c|c|c|c|c|c|}
\hline \multicolumn{15}{|c|}{ Table 1: Descriptive Statistics of 20-item External Stressors } \\
\hline \multicolumn{15}{|c|}{ Financial Crisis } \\
\hline $\begin{aligned} & N \\
= & 148\end{aligned}$ & $\begin{array}{l}\text { Unpa } \\
\text { labou }\end{array}$ & \begin{tabular}{c|c|} 
iid & Underpaid \\
ur & job
\end{tabular} & $\begin{array}{r}\text { Insu } \\
\text { in }\end{array}$ & $\begin{array}{l}\text { fficient } \\
\text { come }\end{array}$ & $\begin{array}{c}\text { Career } \\
\text { uncertainty }\end{array}$ & \begin{tabular}{|c|c} 
High Medical \\
expenses
\end{tabular} & & $\begin{array}{l}\text { lucational } \\
\text { ixpenses }\end{array}$ & $\begin{array}{l}\text { Unexpected } \\
\text { expenses }\end{array}$ & Loan overdue & \multicolumn{2}{|c|}{ Lack of Savings } & $\begin{array}{c}\text { Inability to } \\
\text { Purchase } \\
\text { Assets }\end{array}$ & $\begin{array}{c}\text { Sum of } \\
\text { Mean }\end{array}$ \\
\hline Mean & .55 & .81 & & .28 & 1.45 & .93 & & 1.19 & 1.66 & 1.04 & \multirow{2}{*}{\multicolumn{2}{|c|}{1.94}} & 2.12 & \multirow[t]{2}{*}{12.97} \\
\hline SEM & .095 & .118 & & 139 & .149 & .112 & & .125 & .126 & .121 & & & .154 & \\
\hline \multicolumn{15}{|c|}{ Familial Issues } \\
\hline & $\begin{array}{l}\text { Health } \\
\text { care } \\
\text { work }\end{array}$ & \multicolumn{2}{|c|}{$\begin{array}{l}\text { Family Burdens \& } \\
\text { New Commitments }\end{array}$} & $\begin{array}{r}\text { Exi } \\
\text { New U } \\
\text { Pro }\end{array}$ & $\begin{array}{l}\text { sting/ } \\
\text { nresolved } \\
\text { blems }\end{array}$ & \multicolumn{2}{|c|}{$\begin{array}{l}\text { Unwilling to work at } \\
\text { home/workplace }\end{array}$} & $\begin{array}{l}\text { Patriarchal } \\
\text { life partner }\end{array}$ & $\begin{array}{c}\text { Irresponsible } \\
\text { male family } \\
\text { members }\end{array}$ & $\begin{array}{l}\text { Domestic } \\
\text { violence }\end{array}$ & $\begin{array}{c}\text { Mistreatme } \\
\text { nt by in- } \\
\text { laws }\end{array}$ & $\begin{array}{c}\text { Lack of } \\
\text { trustworthy } \\
\text { people to share }\end{array}$ & $\begin{array}{l}\text { Denial of } \\
\text { rights }\end{array}$ & \\
\hline Mean & 1.32 & \multicolumn{2}{|l|}{1.61} & & 1.69 & \multicolumn{2}{|l|}{1.22} & .62 & .81 & .45 & .47 & 1.12 & .86 & \multirow{2}{*}{10.17} \\
\hline SEM & .129 & \multicolumn{2}{|l|}{.137} & & 137 & \multirow{2}{*}{\multicolumn{3}{|c|}{\begin{tabular}{l|r} 
& .11 \\
$\mathrm{U}_{2}$ Total
\end{tabular}}} & .114 & .092 & .095 & .126 & .121 & \\
\hline & & & & & & & & & & & & & & 23.14 \\
\hline
\end{tabular}

Table 2: Descriptive Statistics of 20-item Internal Stressors

\begin{tabular}{|c|c|c|c|c|c|c|c|c|c|c|c|}
\hline \multicolumn{12}{|c|}{ Psychological Trauma } \\
\hline & $\begin{array}{c}\text { Self- } \\
\text { sympathy }\end{array}$ & $\begin{array}{c}\text { inferiority } \\
\text { complex }\end{array}$ & $\begin{array}{c}\text { Insecurity \& } \\
\text { Fear to face } \\
\text { uncertain future }\end{array}$ & Loneliness & Insomnia & $\begin{array}{l}\text { Anxiety } \\
\text { over } \\
\text { health }\end{array}$ & $\begin{array}{c}\text { Misunderstanding } \\
\text { with others }\end{array}$ & $\begin{array}{l}\text { Depression on } \\
\text { relationships }\end{array}$ & $\begin{array}{l}\text { Inability to } \\
\text { meet loved } \\
\text { ones }\end{array}$ & $\begin{array}{l}\text { Loss of } \\
\text { family } \\
\text { members }\end{array}$ & $\begin{array}{l}\text { Sum } \\
\text { of } \\
\text { Mean }\end{array}$ \\
\hline Mean & 1.63 & 1.32 & 2.37 & 1.99 & 1.72 & 2.03 & 1.68 & 1.70 & 2.64 & 1.18 & 2626 \\
\hline SEM & .139 & .138 & .150 & .158 & .146 & .132 & .129 & .138 & .153 & .139 & 36.26 \\
\hline \multicolumn{12}{|c|}{ Physical Issues } \\
\hline & Fatigue & $\begin{array}{c}\text { Heavy workload } \\
\text { at kitchen } \\
\text { /\&workplace }\end{array}$ & $\begin{array}{l}\text { Less intake \& } \\
\text { Lack of healthy } \\
\text { food }\end{array}$ & Sickness & $\begin{array}{l}\text { Pregnancy } \\
\text { or abortion }\end{array}$ & $\begin{array}{l}\text { Managing } \\
\text { Kids }\end{array}$ & $\begin{array}{c}\text { Late night sleep/ } \\
\text { Lack of sound sleep }\end{array}$ & \begin{tabular}{|c|} 
No Physical \\
exercise/work/ \\
Movement
\end{tabular} & Weight gain & $\begin{array}{c}\text { Physical } \\
\text { Harassment } \\
\text { \&abuse } \\
\end{array}$ & \\
\hline Mean & 1.45 & 2.37 & 1.50 & 1.20 & .28 & 1.36 & 2.43 & 2.00 & 1.90 & .38 & \multirow{2}{*}{-14.87} \\
\hline SEM & .142 & .148 & .129 & .119 & .070 & .148 & .144 & .153 & .147 & .089 & \\
\hline \multicolumn{11}{|c|}{$\mathrm{U}_{1}$ Total } & 51.13 \\
\hline
\end{tabular}


The formula used to calculate weighted average is,

$\mathrm{W}={ }_{\mathrm{i}=1} \sum^{10}\left[\left\{\left(\mathrm{w}_{1} * \mathrm{f}_{11}\right)+\left(\mathrm{w}_{2} * \mathrm{f}_{\mathrm{i} 2}\right)+\ldots\left(\mathrm{w}_{5} * \mathrm{f}_{\mathrm{i}}\right)\right\} / \mathrm{N}\right]$

in which $\mathrm{N}$ is number of respondents, $\mathrm{i}$ is 10 -item of each issue, $\mathrm{f}$ is the frequency of the value given by the respondent, and $w=\{0,1,2,3,4\}$ is the weight assigned. With reference to the values listed in table 1 and table 2 ,

$$
\mathrm{\Psi}_{1}-\mathrm{\Psi}_{2}==>51.13-23.14=>27.99>0
$$

Hence, Null Hypothesis $\left(\mathrm{H}_{1}\right) \mathrm{U}_{1}-\mathrm{U}_{2}<=0$ is disproved and so Alternative Hypothesis $\left(\mathrm{H}_{2}\right)$ is found correct. To sum up, inability to meet loved ones, lack of sound sleep/late night sleep, heavy workload at kitchen/workplace, insecurity \& fear to face uncertain future, inability to purchase assets, anxiety over health and no physical work/exercise/movement were identified as the key stressors of women that also highlighted their attitude towards lifestyle during this pandemic. Thus the data analysis found that psychological and physical issues are more dominating the psychic world of women than the financial and family problems. The research can further be extended to analyse the stress level of women of particular groups like frontliners, migrant labours, NRIs, unemployed, students and so on in order to be specific to the problem domain. When the same variables are found to be dominating using factor analysis and regression, then this can be regarded as Pandemic Perceived Stress Scale.

\section{Conclusions}

The survey had an open ended question to which the respondents replied that they deal with the cruelty of frustration, insecurity, restlessness, lack of belongingness and privacy, loneliness, boredom, misunderstanding, financial loss, pessimistic view, suicidal urge and childcare during this homestay. The perceived stress scale results show that overcoming all these internal stress is not more seemingly an easy go for women than tackling the real life challenges. The research concludes that de-stressing measures would be the perfect panacea for the recovery of resilience power. With the use of technology, women find their vent to destress and establish their own space in virtual environment as writers, entrepreneurs, online trainers and so on. Ursula's remark summarises this innate resilience power of women as "Before the moon I am, what a woman is, a woman of power, a woman's power, deeper than the roots of trees, deeper than the roots of islands, older than the Making, older than the moon." (Le Guin 57)

It is highly appreciated worldwide that the female leaders of various nations are with "resilience, pragmatism, benevolence, trust in collective common sense, mutual aid and humility" (Croteau n.p.) and handle the COVID-19 crisis effectively. Croteau further says, "Greater involvement of women [in administrative sectors and in positions of power] results in a broader perspective on the crisis and paves the way for the deployment of richer and more complete solutions". Women around the world are victims of social, political and psychological snares yet they are warriors fighting tooth and nail to make it through this Pandemic existential crisis. It is the need of the hour to share the power of resilience instead of the virus. 


\section{References}

1. Berjot S., Gillet N. "Stress and coping with discrimination and stigmatization". Frontiers in Psychology. Vol 2, no. 33, 2011. doi: 10.3389/fpsyg.2011.00033

2. Croteau, Anne-Marie and Louise Champoux-Paille. "Why women leaders are excelling during the coronavirus pandemic". The Conversation. 2020. Web.

3. Le Guin, Ursula K. Tehanu. New York: Simon and Schuster, 2008.

4. Pick, Marcelle. "Stress is Where the Heart Is: Home Life and Internal Stress". 2018. Web. https://marcellepick.com/external-and-internal-stress/

5. “The Facts: Women and Pandemics". Canadian Women's Foundation. Web.

6. Vaezi, Shahin and Nasser Fallah. "The Relationship between Self-efficacy and Stress among Iranian EFL Teachers". Journal of Language Teaching and Research, Vol. 2, No. 5, pp. 1168-1174, September 2011 


\title{
SAFETY, SECURITY AND WELL BEING IN TIMES OF COVID 19

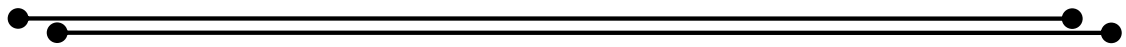

\author{
Dr. M.A. Israth Jahan \\ Associate Professor, Department of English \\ Srimanakular Vinayagar College of Engineering and Technology, Puducherry
}

\begin{abstract}
"There is a single species that is responsible for the COVID-19 pandemic is us. Pandemic means it is spreading worldwide. We have a very small opportunity, to overcome the challenges of the natural calamity." Let us be very realistic for some time, because the COVID virus will not end in any near future. But at the same time, the Trans Boundaries continue to challenge national borders as they always constitute a stark reminder that cooperation between countries is essential, not least to increase resilience to disasters. We are now intensifying our work with capacity-building on topics such as how to tackle disinformation campaigns and dangerous rumours - a growing threat in times of crisis. It is important to act now, to counter growing tensions. This chapter is an endeavour of picturing the current crisis in view of safety, security and well-being.
\end{abstract}

Keywords: Pandemic, Haptic, Proxemics, Cyber-Security, Touch less Technology, Mental Well-being, Preconditions.

\section{Introduction}

COVID-19 is the novel Corona Virus that began in December 2019 in Wuhan and now has spread worldwide. The World Health Organization has declared the COVID-19 as a Pandemic affecting more number of people worldwide. The numbers are growing by the day. How we decide to protect ourselves is usually dependent on where in the world are we situated as some areas are obviously much worse hit than others. The generic guidelines is remain applicable to almost every country. With the huge changes brought about by the pandemic, and looking ahead to the end day it is important that we have to keep up with some safety, security and mental well-being measures. Here are some simple things we can do to protect ourselves and others.

\section{Safety \\ Hygienic Touch}

There is no better way to communicate love and care than through touch. We have learned to be more conscious around the way that we both give and receive touch. Touch was something that happened incidentally. When we're touching, however, others come into direct contact with who we are. There's less hiding, and more intimacy and love. However, the Covid19 pandemic has pinned a giant question mark over the health and safety issues of touching that can feasibly transfer diseases and viruses from one person to another.All the bacterial or viral outbreak changes the way we practice our personal hygiene. We are always aware of the risk of getting infected. By incorporating the precautionary measure we can maintain our personal hygiene. 


\section{Avoiding Self Touch}

Avoid touching our eyes, nose and mouth or face in general. One of the reasons medical professionals recommend the use of a mask is to prevent us from touching our face as viruses enter their body through these parts. Practice basic hand hygiene principles such as washing our hands with a rubbing alcohol, hand sanitizer or a hand wash liquid.

\section{External Touch}

If you are touching surfaces such as taps, floors, tables, books, lift buttons, mobile screens try using our non-dominant hand. Because we are less likely to use that hand on our face or other organs which could help prevent the spread of the virus through such surfaces. Push doors open using our elbow or another part of our body. If we are washing our hands in a public bathroom with paper towel, use the towel to turn off the sink knobs. Use a paper towel to open the door rather than touching the dirty door handle. We should wash our hands after we use the bathroom and before we eat. If we need to use a grocery cart, then make sure that we should wipe it down with disinfectant cart wipes. Use our hand sanitizer after disinfecting the grocery cart. Also, use sanitizer after ringing up our groceries and before we touch the handles on our car. Sanitize our hands before touching your car handles. If we've been outside, wash our hands as soon as we walk through the door of our home. It is mandatory continuing hand hygiene and infection prevention.

\section{Haptics - The Hygienic Solution}

With an increased focus to control infections, multiple organisations are exploring the possibility of developing hygienic technologies throughout society. Multiple research papers are exploring the possibility of touch less interfaces that enables medical personnel to interact with computer equipment without having to use their hands. Touchless technology involves using biometric data, gesture and ultrasound to operate machines without the need to physically touch them. Devices will include haptic and a mix of motion tracking with hands, arms, finger, eyes and legs together with voice recognition.

\section{Respiratory Hygiene}

Practice respiratory hygiene by covering your mouth or nose with a tissue or with our elbow while we sneeze or cough. There is only one thing we need to understand about how a corona virus spreads. The virus spreads when the droplets of sneezing and coughing of others will get into our eyes, nose and mouth. So if see someone is visibly coughing /sneezing /sick, we can choose to keep our distance $2 \mathrm{~m}$ to $0.5 \mathrm{~m}$ to keep us safe for larger droplets or give them a mask they can cough/sneeze into it and protect everyone else healthy. And in general it is a good idea to avoid crowds, because we don't know who might be sick.

\section{Hygienic Proxemics}

Proxemics is basically the body space or bubble we all set around ourselves, in our interactions with those around us on an everyday basis. Social distancing is one of the effective strategies to reduce the novel coronavirus. Without these steps, an individual with COVID-19 can get expected to infect around three others throughout their infection. While going outside 
we have to keep the practice of maintaining social distancing. It will be recommended that we need to stay 6-10 feet away from everybody.

\section{Hygienic Food Habits}

Eat food that helps boost your immunity- consume a lot of orange juice or other drinks rich in vitamin C. Work out at home simple exercises can make your body feel more energetic and your immune system shall function better. If you have a fever or a cold or even a sore throat have the natural medicines and drinks, after that do consult your nearest doctor. If we have children or elderly, make sure to protect them by giving healthy and hygienic foods. When we go out of home and town we must take home made food and water with us. Don't get too consumed or less consumption of food.

\section{Security}

Security means the state of being free from threats or dangers. During natural calamities people have to be secured enough in preventing as well as affected. Here we have received the natural calamity in the form of pandemic Covid 19. Under natural conditions, an infection would almost certainly remain localized and not spread to the pandemic distribution. But if any agency indulge intentionally it will spread and causes major destruction in the society. The list of security measures to be taken during this crisis are given below:

\section{Security from Exploitating the Nature}

So far we have seen that lock-down is having a positive impact on nature. The air is getting cleaner; wildlife is reclaiming the lands occupied by humans etc., but on the other hand, the economy of almost all countries is suffering and nature being ravaged indiscriminately by humans. Therefore, to revive the economy of a country, all are indulging in the activities of rampant deforestation; agricultural expansion and infrastructure development. This will secure the nature from exploitation. Live with due respect with the nature and the odds are humans will lead a happier and healthier life and perhaps longer as well.

\section{Cyber Security during COVID 19}

With the world being quarantined at home, the cybercriminals are making the most of the on-going pandemic. In April 2020 alone, WHO reported that some 450 active official email addresses and passwords were leaked online along with thousands of other credentials - all linked with people working to mitigate the coronavirus impact. The cybercriminals are using fake emails to conduct social engineering campaigns around the pandemic to increase the fear among people. Some of the major industries at risk during the pandemic are hospitality industry, gaming industry, media industry, financial industry, retail industry and education industry. Some of the best practices that organisations can follow to prevent cyber-attacks during COVID-19 are:

1. Conduct meeting on secure platforms

2. Securing the confidential data

3. Cyber security training to employees

4. To mitigate the risks most of the organisations across the world have adopted the customer identity and access management software. 


\section{Security to Larger Socio Economic Crisis}

The Covid-19 pandemic is making this work increasingly difficult but also more important than ever. In addition to the enormous challenges associated with reducing the spread of the Covid-19 virus, the global economic standstill has had dramatic effects in many countries. Many sectors are impacted, including international communication, which is often an important source of income for many countries. The steep drop in oil prices adds to the crisis as it has a huge impact on many economies, not least in the Middle East. WHO warns that the spread of Covid-19 has not yet reached its peak in many regions, and many countries lack sufficient capacity to respond adequately to a crisis of this magnitude? It is not hard to imagine how this can escalate into a larger socio-economic crisis. Before the pandemic, several countries in the Middle East and Northern Africa were already (for example Iraq and Lebanon) experiencing unrest. Demonstrators called for governments to fulfil their basic functions to provide public services such as access to safe water. Such protests could become more frequent if the pandemic escalates, economies collapse, and social contracts are perceived to be broken. The situation is also affected by the global increase in disinformation campaigns, adding to the threat of long-term national stability in many countries. In response to the crisis, we see closed borders and examples of a rise in nationalistic sentiments. Recent pandemics are a direct consequence on our global financial and economic systems, based on a limited paradigm that prizes economic growth at any cost.

In addition, the current crisis could also be turned into an opportunity; it could become a catalyst for a societal transformation into a more sustainable future. People and states have become acutely aware of the global interdependences of economies and the importance of collective, multilateral approaches. Building resilience is key to limiting the impact of future disasters, which could have large negative implications for nations' economic, social and political stability. Future efforts to strengthening resilience to pandemics could also have a positive impact on other sectors, and vice versa as building more resilient systems will increase the overall capacity to maintain functions in the face of external stresses.

\section{Food and Energy Security}

The need for more holistic approaches which link solutions to climate change, global health, energy, water and political stability is increasingly evident. The region's 8.4 million hectares of irrigated agriculture contributes around 20 per cent of the regional GDP, employs a large percentage of the population and plays a key role for food and energy security. Such investments could become an important catalyst for enhanced cooperation and make the region more resilient, not only to pandemics but also to climate change and associated economic threats.

\section{Physical Security}

We had seen more hygienic aspects of body and here I intend to say about the security aspects of our body. They are:

1. For the hand cleaning we need to follow the standard practice adopted by healthcare providers all over the world i.e., using ordinary soap and water instead of expensive liquid disinfectant. 
2. Don't ever spray disinfectant (alcohol content 60\% plus) in a closed environment, in particular inside a vehicle with window shut. Flash fire can kill when triggered by static electricity or someone lighting a cigarette. Remember the "Do not Smoke" sign at gas stations.

3. Don't get near the stove or open fire when your hands are still wet with disinfectant. Your hands will catch fire. Make sure the disinfectant dries thoroughly before going into the kitchen.

4. As surgical mask cannot protect us from virus, N95 mask prevent the virus transmit from others and it prevents the virus to transmit from the person to the others. We should use the mask only once irrespective of its material and cost.

\section{Mental Well-Being}

According to the capability and ability of a person the emotional and mental health will be maintained during a crisis like this pandemic. Every person will have different styles and choices of reacting or responding to the situation. It is very important to care for our emotional, mental and physical issues when we are at home due to coronavirus (COVID-19). We may feel lonely, bored, be low, worried or anxious about our income, our health or those around us. It's usual for everyone to feel this way but we have to remember, that this is a temporary phase and these unpleasant feelings will pass in due course. Though it may be difficult to stay at home we must protect our self and others by doing so. It is a different period of time in our life, and not necessarily a bad one, even if we didn't choose it. It is a different rhythm of life, a chance to be in touch with others in an unusual way. To keep on mental wellbeing we have to be in touch with other people regularly on social media, e-mail or on the phone. Here are some ideas and tricks to keep up our mental well-being as self and with others:

\section{Mental Well-Being of Self}

Today the panic about Covid 19 has triggered through social media and it affected the normal people as well. It is not only a physical issue but also everyone's mental issue. It is necessary to say that all the stress, uncertainty and sudden shift in the way they are working have taken a toll on their mental well-being. Here's a list of how the current COVID-19 scenario is affecting our mental health and how we can tackle the situation.

- Prevailing news about COVID 19 will cause the distress among us, so we have to seek information from trusted resources to prepare our plans and to protect ourselves.

- Use sufficient coping strategy such as rest, healthy well balanced food, regular physical activity and stay in contact with our family members.

- We can try our favourite and easy home workouts.

- Avoid extreme anxieties about the pandemic and stay on top of difficult feelings.

- Set a time to update your act of collecting news about neighbour, street, city etc. Do not stay glued to the news.

- Indulge in pleasure giving acts such as favourite hobby, learning something new etc.

- Try lots for free tutorials and courses for neighbours and their children.

- Use any relaxation technique so as to improve our mental well-being. 
- After waking up we should think about our daily routine and the new works to be done.

- Try to maintain good sleep practices.

- Find something to keep our mind active and it manages our mental health and psychological wellbeing.

- Talk to family members outwardly especially those who are having kids spend time with them. The greatest stress buster in the world is spending time with children.

- Without causing them alarm try to pacify the children by saying the negative impact of COVID 19 and how to be cautious in their daily routine.

- Try to be eustress though we are all surrounded by the pandemic in our area.

- $\quad$ Try not to make assumptions regarding the responsible for the spread of the disease.

- Effective modes of communication have to be used i.e., while communicating with others we have to be compassion, empathy and concern for the safety and well-being of each other.

- Long hours of working in digital modes leads to lack of physical activity. This

- Deskbound work style causes severe health issues such as obesity, low immunity, ortho issues etc., it affects their mental health when coupled with anxiety, fear and depression. During these hours we may practice indoor workouts and also advise others pay heed to their fitness.

- The stress hormone will give over-secretion when we are not following the routine habits or works which we followed before corona. So we have to practice the 'new normal' practises according to the situation which ultimately impacts our physical as well as mental wellbeing.

- All the organizations are headed with financial crisis in this current scenario, and as a result they do pay-cuts, layoffs, reduced tea breaks etc., to the employees. This work panic will severely affect the mental well-being of workers. In such a scenario we have to alleviate and plan according to the income to keep our mind and body free.

- Try to avoid beating around the bush about the negative impacts of pandemic among peer group to maintain our stress levels and their mental health to the maximum.

- Try to measure the work productivity when staying at home which gives us the selfpleasure and proud.

\section{Mental Well-Being for Others}

The greater impact of Coronavirus is likely to have an impact on those with mental illness. It often causes illness behaviour such as fatigue, lethargy and a tendency to not want to interact with people. The impact of social distancing, economic and financial are to be higher for those with mental illness. Keeping in contact with family, friends and community by phone and social media is mandatory in this situation. But at the same time keeping mental wellbeing of others also important for the widespread panic. Here's a list of how the current COVID-19 scenario is affecting others mental health and how they can tackle the situation.

- Working together as one community with the people we trust can create the mental well-being of everyone in the group. 
- Expressing our thoughts with someone we trust is all right and it will benefit them in this current situation.

- We should keep in touch with our friends and family for emotional well-being but we should not try to sensationalize things with them which will affect our well-being.

- Be cautious about the news coverage from others and limit our news intake to maintain everyone's well-being.

- As we are all sailing in the same boat avoid all the challenges and people.

- It is really uneasy feeling when no one feels good and at the time we should not try 'why', because every step of searching the reason will affect everyone's mental wellbeing.

- While media is trying to highlight the importance of mental health we are all have decided to make a timetable that would replicate any regular workday.

\section{Student Well-Being}

The education sector has really been affected by COVID 19 in a positive way. All the education leaders are confronting difficult, high-stakes decisions as they plan for how to reopen schools amid a global pandemic. They must address, including running a socially distanced school, rethinking how to get students to and from school, and making up for learning losses. They present a broad spectrum of options endorsed by public health officials, explain strategies that some districts will adopt, and provide estimated costs. Online teaching which formed just about $5 \%$ of the total teaching system earlier has now become the major mode of the teaching-learning system. Almost all teachers are using this mode to teach, assess, promote interaction, and everything else that can be done in the class except making the child stand up on the bench or given a whack with a cane. The best thing is yet to come. The new National Policy of Education 2019 when adopted will make online learning a supplement to conventional learning. COVID 19 has hastened the process and provided all the teachers hands-on experience without having to undergo the mandatory 'inservice' training programme.

\section{Teachers Well-Being}

The role of the teachers in the present educational scenario is something that is to be scrutinised carefully. The educational environment is not confirmed to the classroom alone; instead it extends in to the home and the community and around the world. Students are not mere consumers of facts. They are active creators of Knowledge. Prompted by massive revolutions in knowledge, information technology and public demand for learning, schools nationwide are slowly restructuring themselves. Teachers have to rethink every part of their jobs, their relationship with students, colleagues, and the community. The also recall the tools and techniques they employ, their rights and responsibilities, the form and content of curriculum. On the whole, teachers are rejuvenating themselves and their occupation to do the better service to their schools and students. 


\section{Safety, Security and Well-Being of Women during COVID 19}

As a biological threat to humanity no plan can escape the fact of this pandemic will affect women in many ways. Civilization has some essential tasks that must not be stopped and cannot be operated without women. The governments do not have the manpower especially women to staff the entire structure and service an entire population held under house arrest. Most of the women community cannot care for themselves under any condition. They are involving themselves in the works like nursing, assisted living and in home-care. It has been determined that COVID-19 is most dangerous to women and those with compromised immune systems.

Moreover pregnant women do not appear to be more susceptible to the consequences of infection with COVID-19 than the general population. Though data are limited the special consideration has been given to pregnant women with connected medical illnesses who could be infected with COVID-19 until the evidence base provides clearer information. There are no reported deaths in pregnant women at the moment. Likewise there is no evidence that a mother can infect her baby with the coronavirus while pregnant or that infants can be infected during birth.

The priorities are the provision of safe care to women with suspected/confirmed COVID19 and the reduction of onward transmission. Women should be aware that this is very much an evolving situation and the guidance spreads through media are the living document that may be updated if or when new information becomes available.

\section{Preconditions to Make it a Worldwide Success}

\section{Mentally Changing The Mind set}

First and foremost, we need to adopt the right mind set, realizing and admitting that it is our responsibility, as an individual and as a member of the community, to adhere to a workable series of personal / public hygiene measures. Government and health organization can help a lot, but ultimately we alone are our number-one life protector.

\section{Physically Internalizing A Set of Personal Protective Measures}

Noted that the mainstream media are flooded with news focusing on how the government should do to save the economy and the people, but little airtime has been dedicated to giving education on the how-to on self-protect and self-save techniques. If we track the social media to find out self-help measures, there are innumerable new tricks and ideas discovered and shared by people that always help us a lot.

3. Winning or Losing This Pandemic War, Now, The Destiny is in our own Hands. All in all, to keep ourselves and others safe, take ownership of the strive-for-survival mission in our own hands and carry out effective personal protective measures. It not only protect and preserve lives but also the life of others too. It is absolutely not a good time to be wandering around contacting people. It's a good time to stay home. If we diligently do those things we greatly reduce the chances of getting $\mathrm{C}-19$, and perhaps even other common viral infections as well. 


\section{Conclusion}

\section{End of COVID 19 a Prediction}

Coronavirus will never, ever be over. If the Coronavirus found a good host, it is part of the host species' existence forever. The fact is that this is just my opinion, and nobody knows the truth just yet. It is the fear of the unknown that is worse for many people. This virus has shown itself to be very contagious with short incubation period in humans. The pandemic however will end as we will be able to appreciate when we get some idea about the virus and some of its prominent properties. Due to the social-psychological issue of exhaustion and frustration, people want to go back to their regular life. Everyone has the same question - "When will this pandemic end?"Some historians believe that pandemic has two types of endings -

1. Social ending - When the epidemic of fear about the disease wanes. In this ending, end occurs not because the disease has been vanquished, but because people grow tired of the panic mode and learn to live with a disease.

2. Medical ending - When incidence and death rates plummet.

However it ends when every human on earth takes full responsibility of his/her personal hygiene seriously, and at the same time, adopts and puts to practice a comprehensive set of common-sense personal protective measures.

\section{References}

1. Children's story book released to help children and young people cope with COVID-19, News release of the Inter-Agency Standing Committee by Alison Bruner, Communications Officer, World Health Organization.

2. Mental health and psychosocial considerations during the COVID-19 outbreakPublished by WHO.

3. COVID-19 11 Tips and 10 Examples for Communicating to .www.e-spirit.com > blog > covid-19_10_tips 


\title{
ELDERLY WOMEN'S SPIRITUALITY AND WELL-BEING: SCRUTINIZING THE DIMENSIONS OF RELIGIOSITY AND SPIRITUALITY FOR EMPOWERMENT IN POST-PANDEMIC TIMES
}

\author{
Dr. Irum Alvi \\ Assistant Professor, HEAS Department \\ Rajasthan Technical University, Kota
}

\begin{abstract}
Elderly women tend in general to have high attachment to religion as well as spiritual undertakings and are associated with expanding pervasiveness of religious and spiritual acts. In spite of ever-growing research on religion, religiosity, spirituality and wellbeing, there is a scarcity of exploration and studies and research on the relationship among these select factors and wellbeing with respect to women empowerment. As a step toward this, the literature on the effect of religion, religiosity and spirituality on wellbeing of the elderly is reviewed. Numerous gaps exist in current information related to the elderly and their wellbeing, especially in times of Pandemics. The present chapter aims to fill the gaps by reviewing and inspecting select literature. Health advantages originating from profound influence of religiosity and spirituality for the Elderly women could be significant, and this is especially the case given the ground realities of the post-pandemic existence. The discourse to follow consequently distinguishes between religiosity and spirituality, and establishes the key part they play in the wellbeing of the Elderly women, with specific focus on complexities and complication arising after COVID 19 pandemic. The exposition covers a few themes. The first section starts by characterizing and defining religiosity and spirituality from a global as well as Indian perspective. Proof is given that joins religiosity and spirituality to health of the Elderly. This leads into a discourse on the pandemic situation, trailed by a concluding statement. Despite the fact that, there is proof that religiosity and spirituality are related with better wellbeing, there still exists the requirement for a cohesive and amalgamated way to deal with seeing how religiosity and spirituality impact on wellbeing in context of the empowerment in post-pandemic times. The study is instigated by the immense significance of the concept to meet the needs of the time and create understanding and comprehension of religiosity and spirituality for the different specialist service providers, associations, strategy makers and researchers actively involved in providing support to the Elderly women.
\end{abstract}

Keywords: Religion, Religiosity, Spirituality, Pandemic, Wellbeing

Great development has taken place in the bulk of scholarly investigations which scrutinizes the association between Religion, Spirituality and Wellbeing of the Elderly. Studies by scholar Argue et al. (1999) and Levin et al. (1994) recommend the Elderly have a tendency to be more religious-minded than the youth. This is valid for the Elderly women too. They come from a period where religion was more esteemed and have retained the previous values and qualities, as per Wilhelm in et al., (2007). In addition, Wink and Dillon, (2001) confirm they grow more inclined towards religion and their feeling of spirituality amplifies with time. The Elderly women show more engrossment in religious/spiritual actions and additionally are related with expanding and increasing religious and spiritual acts. In spite of expanding 
research on religiosity, spirituality and wellbeing, there is a dearth of exploration on the connection between religiosity, spirituality and wellbeing with respect to the Elderly women, particularly during the pandemics. . Numerous gaps exist in current information related to the elderly and their wellbeing, especially in times of Pandemics. Numerous past studies have been conducted in the USA and Europe. Additionally, the above-mentioned concepts particularly spirituality can be harder to characterize and define as well as distinguish from religiosity; nonetheless, both are significant particularly for the wellbeing of the Elderly women during the Pandemic times. The present chapter inspects select literature that reveals insight into the wellbeing of the Elderly: spirituality is prevalent all inclusively all over the world, more in India than anywhere else. Health advantages that may originate from profound contributions of religiosity and spirituality for the Elderly women could be significant, and; this is especially the situation given the ground realities of the post-pandemic existence. The discourse to follow consequently distinguishes between religiosity and spirituality, and establishes the key part they play in the wellbeing of the Elderly women, with specific focus on complexities and complication arising after COVID 19 pandemic. The exposition covers a few themes. The first section starts by defining spirituality from a global as well as Indian perspective. Proof is given that links religiosity and spirituality to health of the Elderly. This leads into a discourse on the empowerment, trailed by means for enhancing the wellbeing of the Elderly women, followed by a concluding statement.

\section{Statement of Problem}

Religiosity, Spirituality and wellbeing of the elderly women in Post-Covid times present a moderately new sphere of exploration and research. There exist a lot of studies about Religiosity and Spirituality yet there is a shortage of verification and information about the association and connection among Religiosity and Spirituality and wellbeing of the elderly women during Pandemics, which would help empower them.

\section{Characterizing and Defining Religiosity and Spirituality}

All religions around the globe by and large connect with explicit primary rules that are composed around unmistakable frameworks of convictions, practices and customs that exist inside networks of religious groups. Spirituality is harder to characterize and define, especially across societies, as its qualities are not effortlessly settled upon, and it represents various things for various people in various places. Additionally, Crowther et al. (2002) discovered that Spirituality expresses the thought of an individual inquiring about things which are sacred and holy and transcendental in nature. While religiosity can be estimated in direct manner, by evaluating recurrence of religious acts and exercises, for example, participation at temples, mosque, and synagogues etc., Spirituality is estimated in more backhanded terms, for example, the quest for significance, harmony and individual satisfaction, and consideration about meaningfulness of life. Religious-minded acts and movements are typically thought to happen inside or in association with formal foundations while spiritual actions occur on a more close to personal level. This doesn't intend to state that religion is fundamentally an open public undertaking. Eastern religions, for example, Buddhism and Hinduism, involve a more prominent level of private rites than the other religions. These can include petition, reciting, singing and listening in to serenades, chants and religious lessons. 
It is hard to define what Religiosity and Spirituality constitutes for the Elderly women, as no appropriate definitions exist. Moreover, the two notions are very similar. Seybold and Hill (2001) maintain the two notions are correlated and have similar traits. A strictly religiousminded Elderly woman may characterize herself as being other worldly with the goal that spirituality frequently includes religiosity. The Elderly women while praying may consider it some form of a conversation that is internal, with a heavenly power or an inner purer self. They may also believe that their meditation and mindfulness is merely an endeavour to delve deep inside, and an endeavour at being intensely conscious of their moods, feelings and practices. They may think religiosity and spirituality are the same as they involve prayer and meditation and provoke relaxation, and assist in identifying meaning and reality of life.

\section{Indian idea of Spirituality}

As there is no consistently concurred meaning of Spirituality, it might be expected that it alludes to a procedure of recuperation/rebuilding for which various individuals utilize various modes, for instance the Torah in Judaism, Jesus Christ in Christianity, Buddha in Buddhism and Muhammad in Islam. However, the meaning of Spirituality in an Indian setting is unique. Indians have no conventional categorization, no focal point dedicated authority, no overseeing bodies, or any prophets who go about as ideals. One may decide to be pantheistic, polytheistic, monistic, or agnostic in the continued quest for Spirituality. The form of Spirituality in Indian Philosophy (Sanskrit: darśana) turns out to be all the more frequently an individual or personal encounter (Sanskrit: ksaitrajña), transforming into a profound practice as a person's excursion towards moksha, attention to self, the revelation of higher certainties, genuine nature of the real world, and an awareness that is unrestricted and gratified.

In contemporary times, Spirituality for the elderly women may consolidate selfimprovement or change, for the most part in participating in organized religious activities. At times, it may turn into a blend of mystical and traditional rites performed by the Elderly in unison with family or community. It merits referencing that the Indian notion of Spirituality varies from the Western and Christian reasoning one which will in general separate the physical from the profound, the lands from people, and a person from community, particularly the Elderly from the society. Contrasting with Western thoughts regarding Spirituality, wherein one sees a division in the midst of normal and social, amid material and profound, amid past and present and amid subject and object, Indian Spirituality has an extensive past. Spirituality leads to the comprehension of the atman, or the soul or spirit, which denotes selfrealization. Thus, Indian understanding varies from Western understanding of Spirituality. As the present study asserts Spirituality offers everyone a possibility for a novel and conceivably hoisting approach leading to wellbeing by associating mind, soul and body.

\section{Association between Religion, Spirituality and Wellbeing}

There has been a lot of development in the volume of scholarly investigations into the linking amid Religiosity, Spirituality and wellbeing. Prior examinations prominently by specialists, for example, Hummer et al., (2004), Koenig et al.(2012), Seeman et al., (2003) just to name a few have demonstrated significant advantages emerging from religious and spiritual influence on wellbeing. An association between religiosity or spirituality and wellbeing has been perceived for quite a while by famous researchers, particularly Koenig et al., (2012) etc. 
The academic discourse brought to the fore more noticeable results during the 1980s and 1990s with compelling examinations that concentrated on well-being such as Bergin, (1983) and Koenig $(1989,1998)$. Lavretsky (2010) discovered religion bring about constructive impacts on handicapped and depressed Elderly people. As of late, more investigations have been conducted, aimed at finding the influence of Religion and Spirituality on the strength of the Elderly, and the connections between religiosity and longer life by Dupre et al. (2006), and Hummer et al. etc. Apart from that the link between religiosity, Spirituality and wellbeing, the other associations such as cardiovascular conditions and regular religious attendance among the Elderly by Sørensen et al. (2011); disability and incessant agony, even diseases such as cancer have been discovered. There is likewise solid proof of an association among religiosity, spirituality and emotional well-being as indicated by Musick et al., (2000), and decreased levels of depression and tension, especially among the Elderly. Atchley (2009) in his book on Spirituality and wellbeing shows associations between Spirituality and wellbeing. Spirituality' solid relationship with both mental and physical wellbeing have been established by Ballew et al.(2012),and Saad et al., (2010), pandemic Chirico (2020) particularly with regard to the Elderly by Kirby et al., (2004) and others. Prayers and chants offered by the Elderly women affect their stress-coping strength. Meditation and Prayers by the Elderly women also result in a feeling of satisfaction and sentiments of general prosperity. Meditation emphatically may positively impact and alleviate a large group of physical issues being faced by them.

\section{Elderly Women and Spiritual Empowerment}

Religiosity and spirituality hold the way to empowerment and freedom for the Elderly women. They may help in raising the status of Elderly women in the society. Economic autonomy and financial security may confer confidence to them. Nonetheless, if the Elderly are not well-equipped with religiosity and spirituality, it would become hard to sustain during difficult times such as the Pandemics. Spirituality is tied in with arousing the 'cognizance/consciousness' that all have been endowed with. The awareness of 'reality with regard to the self, about the relationship of the self and with others is quintessential for the Elderly women. This cognizance causes them to comprehend and get mindful of themselves and everything that affects their internal harmony and contentment. This mindfulness is engaging in light of the fact that it is the start of dealing with the self. It is empowering, as it draws its mettle from ages of spiritual truth, gives them courage to learn from their inner selves, to take apt actions based on their authentic self, and the courage to be enlightened by the inner fire within them.

Based on the above discussion, the next section delineates some ways in which the Elderly women may feel empowered from religion and spirituality during the Pandemic, which will improve their wellbeing:

Religion and spirituality may promote healthy attitudes among the Elderly women. Religious-minded Elderly women are more dedicated to healthy ways of life, and numerous religions inculcate negative perspectives on tobacco, liquor, drugs, illicit sex etc. Spirituality seems to be related with the practice of yoga or meditation or exercise. It also evokes and permeates a feeling of self-control and poise. All this can be beneficial for the Elderly women during the Pandemic. 
Pandemic causes stress for all as noted by Lima(2020).Bäuerle (2020) study reveals the need for Psychological support in times of COVID-19. Religiosity and Spirituality may help them in times of stress and help in adapting to unpleasant events. As Pargament (1997) and Pargament and Raiya (2007) maintain the central aim of religion is to aid the face of distress. This is significant for the Elderly women who may have to adapt to loss of a loved one, forfeiture of psychological and corporeal ability and fear of their own death. By inciting a meaning to life, religiosity and spirituality may support life fulfilment, hopefulness and confidence, all of which act to diminish the distressing effects of the Pandemic.

In short, the Elderly will benefit from praying, staying connected emotionally despite maintaining social distance, being grateful for small things life has to offer, and by engaging in meaningful work. Based on the vast literature, which deals with religiosity and Spirituality and its effect on the wellbeing of the Elderly women, several benefits can be achieved through enhanced understanding of the associations of Spirituality and Religiosity with wellbeing in mature age.

\section{Conclusion}

To summarize, the chapter furnished substantiation that Religiosity and Spirituality remain related with better wellbeing, and filled the gaps which existed, indicating that there is a need for an integrated approachor method to deal with the two concepts and their impacts on wellbeing of elderly women, in particular during the post-pandemic times. The study was initiated by the immense prospective the concept has to create appreciation and understanding of spirituality and its relationship to the elderly women's emotional wellbeing for the various service providers, organizations, policymakers and researchers working for the benefit of the elderly women. It fulfilled its aim to deal with the background, the array of ideas and concepts and complexity of the subject including the connection between Religiosity and Spirituality and wellbeing during the global pandemic.

\section{Limitations}

The present chapter emphatically highlights a requirement and even a commitment to investigate the association between Religiosity, Spirituality and the Elderly women's wellbeing as to empower them and to improve human wellbeing and the human condition. However, the current study has its own limitations. Only a select number of prior studies were dealt with and reviewed. More methodical and systematic studies may shed light on religion, religiosity and spirituality and their connections with wellbeing. The arena of Religiosity, Spirituality and Wellbeing is still a developing one. As such more advanced studies are needed to effusively appreciate and comprehend the influence of religiosity and spirituality on elderly women's wellbeing and its association with empowerment, especially during a pandemic.

\section{References}

1. Argue, A., Johnson, D. R., \& White, L. K. (1999). Age and religiosity: Evidence from a three-wave panel analysis. Journal for the Scientific Study of Religion, 38, 423-435.

2. Atchley, R. C. (2009). Spirituality and aging. Baltimore: Johns Hopkins University Press. 
3. Ballew, S. H., Hannum, S. M., Gaines, J. M., Marx, K. A., \& Parrish, J. M. (2012).The role of spiritual experiences and activities in the relationship between chronic illness and psychological well-being. Journal of Religion and Health, 51, 1386-1396.

4. Bäuerle A, Skoda EM, Dörrie N et al. Psychological support in times of COVID-19: the Essen community-based CoPE concept. J Public Health (Oxf) 2020.

5. Bergin, A. E. (1983). Religiosity and mental health: A critical reevaluation and metaanalysis. Professional Psychology: Research and Practice, 14, 170-184.

6. Chirico F, Nucera G. An Italian Experience of Spirituality from the Coronavirus Pandemic.Journal of Religious Health. 2020 May 18:1-3. doi

7. Crowther, M. R., Parker, M. W., Achenbaum, W. A., Larimore, W. L., \& Koenig, H. G.(2002). Rowe and Kahn's model of successful aging revisited positive spirituality The forgotten factor. The Gerontologist, 42, 613-620.

8. Dupre, M. E., Franzese, A. T., \&Parrado, E. A. (2006). Religious attendance and mortality: Implications for the black-white mortality crossover. Demography, 43, 141164.

9. Hummer, R. A., Ellison, C. G., Rogers, R. G., Moulton, B. E., \& Romero, R. R. (2004). Religious involvement and adult mortlaity in the United States: Review and perspective. Southern Medical Journal, 97, 1223-1230.

10. Kirby, S. E., Coleman, P. G., \& Daley, D. (2004).Spirituality and well-being in frail and nonfrail older adults. The Journals of Gerontology Series B: Psychological Sciences and Social Sciences, 59, P123-P129.

11. Koenig, H. G. (1989). Research on religion and mental health in later life: A review and commentary. Journal of Geriatric Psychiatry, 23, 23-53.

12. Koenig, H. G., Larson, D. B., Hays, J. C., McCullough, M. E., George, L. K., Branch, P. S., et al. (1998). Religion and the survival of 1010 hospitalized veterans. Journal of Religion and Health, 37, 15-30.

13. Lavretsky, H. (2010). Spirituality and aging.Aging Health, 6, 749-769.

14. Levin, J. S., Taylor, R. J., \& Chatters, L. M. (1994). Race and gender differences in religiosity among older adults: Findings from four national surveys. Journal of Gerontology, 49, S137-S145.

15. Lima CKT, Carvalho PMM, Lima I et al.The emotional impact of coronavirus 2019-nCoV (new coronavirus disease). Psychiatry Res 2020;287:112915.

16. Musick, M. A., Traphagan, J. W., Koeing, H. G., \& Larson, D. B. (2000).Spirituality in physical health and aging. Journal of Adult Development, 7, 73-86.

17. Pargament, K. I. (1997). The psychology of religion and coping: Theory, practice and research. New York: Guilford.

18. Pargament, K. I., \&Raiya, H. A. (2007). A decade of research on the psychology of religion and coping: Things we assumed and lessons we learned. Psyke \& Logos, 28, 742-766.

19. Roman NV, Mthembu TG, Hoosen M. Spiritual care - 'A deeper immunity' - A response to Covid-19 pandemic. Afr Journal Prim Health Care Fam Med. 2020 Jun 15;12(1):e1e3.

20. Saad, Z. M., Hatta, Z. A., \&Mohamad, N. (2010).The impact of spiritual intelligence on the health of the elderly in Malaysia. Asian Social Work and Policy Review, 4, 84-97. 
21. Seeman, T. E., Dubin, L. F., \&Seeman, M. (2003). Religiosity/spirituality and health: A critical review of the evidence for biological pathways. American Psychologist, 58, 5363.

22. Seybold, K. S., \& Hill, P. C. (2001).The role of religion and spirituality in mental and physical health. Current Directions in Psychological Science, 10, 21-24.

23. Sørensen, T., Danbolt, L. J., Lien, L., Koenig, H. G., \& Holmen, J. (2011). The relationship between religious attendance and blood pressure: The HUNT study, Norway. The International Journal of Psychiatry in Medicine, 42, 13-28.

24. Wilhelm, M. O., Rooney, P. M., \& Tempel, E. R. (2007). Changes in religious giving reflect changes in involvement: Age and cohort effects in religious giving, secular giving, and attendance. Journal for the Scientific Study of Religion, 46, 217-232.

25. Wink, P., \& Dillon, M. (2001). Religious involvement and health outcomes in late adulthood In: T. G. Plante, \& A. C. Sherman (Eds.), Faith and health: Psychological perspectives (pp. 75-106). New York: Gulford Press. 


\title{
HEALTH ANXIETY AMONG \\ FEMALE STUDENTS DURING COVID-19
}

\author{
Dr. K. Vellaichamy \\ Assistant Professor, Department of Education \\ Madurai Kamaraj University, Madurai
}

\begin{abstract}
Health anxiety sufferers gripped by their physical self in this pandemic period. Sufferers find it impossible to divert their thoughts away from constantly monitoring their body for aches, pains or strange sensations. Health anxiety causes sufferers to check their pulse, listen to their hearts, take their blood pressure and study medical information, surfing the internet to find explanations of each and every symptoms, sensation or thought which arises.

Health anxiety is very destructive. It causes the sufferers to focus on themselves, disregard others, their work, their daily routines and even their personal hygiene. Sufferers often become withdrawn from society, developing corona to prevent exposure to anxiety provoking in this covid-19 situations.
\end{abstract}

Keywords: Health Anxiety and Female Students.

\section{Need for the Study}

Health anxiety refers to fear related to developing a dangerous health problem or already having one. We all worry about our health from time to time. Worrying about our health can lead us to improve our lifestyle; there are many reasons why someone worries too much about their health. You may be going through a particularly stressful period of your life. Health anxiety which also influences illness behavior refers to a concern about health in the absence of pathology or excessive concern when there is some degree of pathology (Lucock \& Morley, 1996). Health anxiety is an important new diagnosis that is increasing in frequency because of changing attitudes towards health, particularly excessive use of health information on the internet. Anxiety can be a protective mechanism; it keeps us alert to possible dangers around us, and so scanning the body for signs and symptoms of illness, injury, or disease may seem like a sensible thing to do. However, when we are preoccupied with something, we tend to notice it more, and we may notice something that we previously would not have paid any mind to, and these sensations can become amplified and can even last longer. When there is an outbreak of disease or illness around the world, it is easy to get overwhelmed by the amount of media coverage, fear mongering, and health warnings. It is quite common to feel a rise in anxiety at times like this, however, panicking prematurely.

\section{Terms and Definitions}

Health Anxiety: refers to a concern about health in the absence of pathology or excessive concern when there is some degree of pathology.

Female Students: refers to the B.Ed. students in Madurai district. 


\section{Variables of the Study}

\section{Dependent Variable}

- Health Anxiety

- Academic Achievement

\section{Independent Variables}

- Nativity (Rural / Urban)

- Family type (Joint / Nuclear)

- Education generation (First / Others)

\section{Objectives of the Study}

- To evaluate the stage and significant influence of health anxiety among the female students during covid-19 period.

\section{Hypothesis of the Study}

- Each of the demographic variables involved in this study exerts a significant influence on health anxiety among female students during covid-19 period.

\section{Methodology Adopted}

\section{Sample of the Study}

A random sample of 320 B.Ed. female students in Madurai district.

\section{Tools used}

1. General Information Sheet developed by the Investigator.

2. Health Anxiety Scale constructed and developed by the Researcher.

\section{Statistical Treatments}

The statistical treatments employed in the study are listed below:

1. Mean

2. Standard Deviation

3. ' $\mathrm{t}$ '- test

\section{Analysis of Data}

\section{Health Anxiety and Nativity}

Table 1: Statistical measures of health anxiety among B.Ed. students (Nativity-Wise)

\begin{tabular}{|c|c|c|c|c|c|c|}
\hline Variable & $\begin{array}{c}\text { Sub- } \\
\text { category }\end{array}$ & $\mathbf{N}$ & $\mathbf{M}$ & S.D. & $\begin{array}{c}\text { 't'- } \\
\text { value }\end{array}$ & $\begin{array}{c}\text { Significance } \\
\text { at 0.05 level }\end{array}$ \\
\hline \multirow{2}{*}{ Nativity } & Rural & 185 & 33.32 & 3.64 & -8.218 & Significant \\
\cline { 2 - 5 } & Urban & 135 & 38.81 & 7.12 & & . \\
\hline
\end{tabular}

It is witnessed from table 1 that,

- Obtained ' $\mathrm{t}$ ' value -8.218 is greater than the table value 1.96 at 0.05 level of significance. 
- This shows that there is a significant difference between the rural and urban students in terms of health anxiety.

\section{Health Anxiety and Family Type}

Table 2: Statistical measures of health anxiety among B.Ed. students (Family type -Wise)

\begin{tabular}{|c|c|c|c|c|c|c|}
\hline Variable & Sub-category & $\mathbf{N}$ & $\mathbf{M}$ & S.D. & 't'- value & Significance at 0.05 level \\
\hline \multirow{2}{*}{ Family type } & Joint & 59 & 38.12 & 6.67 & \multirow{2}{*}{2.884} & \multirow{2}{*}{ Significant } \\
\cline { 2 - 5 } & Nuclear & 261 & 35.47 & 4.86 & & \\
\hline
\end{tabular}

It is witnessed from table 2 that,

- Obtained ' $t$ ' value 2.884 is higher than the table value 1.96 at 0.05 level of significance.

- This shows that there is a significant difference between joint and nuclear families students in terms of health anxiety.

\section{Health Anxiety and Education Generation}

Table 3: Statistical measures of health anxiety among B.Ed. students (Education generation -Wise)

\begin{tabular}{|c|c|c|c|c|c|c|}
\hline Variable & $\begin{array}{c}\text { Sub- } \\
\text { category }\end{array}$ & $\mathbf{N}$ & $\mathbf{M}$ & S.D. & 't'- value & $\begin{array}{c}\text { Significance } \\
\text { at 0.05 level }\end{array}$ \\
\hline \multirow{2}{*}{$\begin{array}{c}\text { Education } \\
\text { generation }\end{array}$} & First & 247 & 36.35 & 5.53 & \multirow{2}{*}{-0.377} & $\begin{array}{c}\text { Not } \\
\text { Significant }\end{array}$ \\
\cline { 2 - 7 } & Others & 67 & 36.67 & 6.35 & & \\
\end{tabular}

It is witnessed from table 3 that,

- Obtained ' $t$ ' value -0.377 is lower than the table value 1.96 at 0.05 level of significance.

- This shows that there is no significant difference between first and other education generation students in terms of health anxiety.

\section{Hypothesis Verification}

Each of the demographic variables involved in this study exerts a significant influence on health anxiety among female students during covid-19 period.

The test of significance of difference between the mean scores of health anxiety among B.Ed. students is dependent upon nativity and family type.

Hence the hypothesis maximally accepted.

\section{Conclusions}

The major conclusions arrived at from the study are listed below:

1. Urban B.Ed. students have more health anxiety than rural students.

2. Joint families' B.Ed. students have more health anxiety than nuclear families' students.

\section{References}

1. https://www.bjmp.org/content/health-anxiety-medical-students-comparative-studytaif-university-medical-student-s-syndrome-revisited 
2. https://www.kcl.ac.uk/ioppn/depts/psychology/research/researchgroupings/cadat/ research/health-anxiety-questionnaires

3. https://www.nmu.edu/education/sites/DrupalEducation/files/UserFiles/Dobson_Cas sie_MP.pdf

4. https://www.thelancet.com/journals/lancet/article/PIIS0140-6736(05)79059$0 /$ fulltext

5. https://www.tandfonline.com/doi/abs/10.1080/10615806.2014.888061?src=recsys \&journalCode= gasc 20 


\title{
EFFECTS OF SOCIO-PSYCHOLOGICAL, POLITICAL AND EDUCATIONAL IMPACT OF WOMEN
}

\author{
P N Vinod Kumar \\ Research scholar (Sociology), Madurai Kamaraj University, Madurai \\ Dr. C. Karuppiah \\ Head, Department of Sociology, Madurai Kamaraj University, Madurai
}

\begin{abstract}
India is a country where there were women who went in search of rights to hide breasts. If we look at the history books (Channar riots), we can understand that the Indian women's movement bravely faced the period when the lower castes were not given the right to cover their breasts. But today the feminist movement is full of exaggeration. It has been years since the beginning of women's scientific activities in the general society. The work order dictated to men by physical structure was dictated to women as the shadow of men in society. But the changes brought about by egalitarian thinking have begun to bring women into the leadership. However, the traditional thinking that has been followed over time has led to violence against women. This study finds the importance of training women at an early age to change the psychological state of being a victim of this violence.
\end{abstract}

Keywords: women empowerment, social bond theory, Gender

\section{Introduction}

Women's empowerment has taken over the world today. In this generation, more and more women are gaining more than men. However, most women are not ready to forget or correct the existing practices. The following factors are responsible for women empowerment in India(a) Education (b) Elimination of Gender Discrimination (c) Steps for implementation of Women Development Programme and various Acts (d) Action for Organization of Awareness Programmes (e) Rule of Mass Media (f) Change of Attitude of Women. Women's empowerment will be effective if it works with the aim of Today, women have reached the pinnacle of education. The second factor is gender discrimination and efforts should be made to replace it. The mentality of working as a slave to man and woman from time to time lies like a petroglyph in the social mind. Actions must be taken politically, socially and psychologically to change this mental evil. For that, the other four elements, one by one, must be taught to the mind from an early age for the transformation of women into egalitarian society.

\section{Back ground of the Study \\ Understanding Gender -What is gender?}

"Gender" refers to the socially constructed roles, rights, responsibilities, possibilities, and limitations that, in a given society, are assigned to men and women- in other words, to what is considered "masculine" and "feminine" in a given time and place. Gender is different from "sex", which refers to the biological and physiological characteristics of male and female animals: genitalia, reproductive organs, chromosomal complement, hormonal environment, etc. People are born female or male but learn to be girls and boys who grow into women and 
men. This learned behavior makes up gender identity and determines gender roles. There are at least four major areas in which men and women are expected to differ, what are the major areas of gender-based differences? "Gender-based division of labor in almost all societies, women and men perform different activities, although the nature and range of these activities vary across classes and across communities. They have also changed over time. Women are typically responsible for childcare and household work, but they also engage in producing goods for household consumption or for the market. Men are typically "bread-winners" and held responsible for meeting the household's needs for food and resources. (TKS(ed), 2000)

\section{Gender-based violence: definitions}

Violence is the use of physical force or power, or threat of such use, against oneself, another person or a group or community, with the aim of causing injury, death, psychological harm or deprivation, whether or not such harm actually happens ",

The term gender-based violence has been used to describe many different acts, ranging from murder and rape to sexual harassment and emotional abuse. Clarity on the team's used is important to better understand the magnitude and dimensions of the problem and assess its health comequences. The UN Declaration on the Elimination of Violence against Women (TKS, 2000)defines gender- based violence to include any act that results in or is likely to result in, physical, sexual or psychological harm or soldering to women including threats of such acts, coercion or arbitrary deprivation of liberty, whether occurring in public or private life. Article 2 of the Declaration further specifies that gender-based violence should include, but not be limited to: Acts of physical, sexual and psychological violence whether they be in the family or the community violence, rape including marital rape, traditional practices harmful to women such as female genital mutilation, non-spousal violence, sexual harassment and intimidation, trafficking in women, forced

\section{Types of gender-based violence}

The Centre for Diseases Control in the US (6) has defined four different types of violence:

- Physical violence

- Psychological or emotional abuse and violence

- Sexual violence, and Threat of physical or

- Sexual violence Physical violence

\section{Physical violence}

This includes the intentional use of physical force with the potential for causing death, disability injury or harm. Physical violence includes, but is not limited to

- Scratching

- Pushing

- Shoving

- Grabbing Supra.

- Choking

- Shaking

- Hair pulling 
- Sunders

- Hitting

- Burning

- Use of a weapon (a gun, knife, or any other object),

- Holding someone down using one's body, size or strength against that person.

Forcing other people to perform any of the above actions has also been classified as physical violence.

\section{Psychological or emotional abuse violence}

This includes trauma to the victim caused by acts, threats of acts, or coercive tactics, such as those given in the list below:

Humiliating the victim; controlling what the victim can and cannot do; withholding information from the victim;

Getting annoyed if the victim disagrees; Deliberately doing something to make the victim feel diminished (eg., less smart, less attractively)

Deliberately doing something that makes the victim feel embarrassed;

Taking advantage of the victim;

Disregarding what the victim wants; isolating the victim from friends and family;

Prohibiting access to transportation or telephone;

Getting the victim to engage in illegal sexual activity

However, it has been felt that this list is not exhaustive and can be extended to include many other types of behavior that could be considered as emotionally abusive by the victim (6). When psychological emotional abuse is accompanied by physical and/or sexual violence, it is called psychological violence.

\section{Sexual violence and abuse}

Sexual violence can be divided into three categories

- Use of physical force to compel a person to engage in a sexual act against his or her will, whether or not the act is completed.

- An attempted or completed sex act involving a person who is unable to understand the nature or condition of the act, to decline participation, or to communicate unwillingness to engage in the sexual act (for example, because of illness, disability or the influence of alcohol or other drugs or due to intimidation or pressure). The sex act or has been defined as contact between the penis and the vulva or the penis and the anus involving penetration, however slight; contact between the mouth and the penis.

Sexual harassment/abuse includes intentional touching directly, or through the clothing, of the genitalia, anus, groin, breast, inner thigh, or buttocks of any person against his or her will or of any person who is unable to understand the nature or the condition of the act, to decline participation, or to communicate unwillingness to be touched (e g. because of illness, disability, or the influence of alcohol or other drugs, or due to intimidation or pressure).

Unwelcome verbal conduct of a sexual nature such as sexually suggestive remarks or lewd remarks propositions or pressure for sexual activity is also counted as sexual harassment or abuse. 


\section{Threat of physical or sexual violence}

The use of words, gestures or weapons to communicate the intent to cause death, disability, injury or physical harm is defined as threat of physical violence. Threat of sexual violence includes the use of words, gestures or weapons to communicate the intent to compel a person to engage in sex acts or abusive sexual contact when the person is either unwilling or unable to consent. For example, statements such as " I'll kill you", "I'll beat you up if you don't have sex with me"; brandishing a weapon; firing a gun into the air; making hand gestures; reaching towards a person's breasts or genitalia, are all included in the definition of threat of sexual violence. (Saltazman LE, 1999)

\section{Methods}

- The study was carried out through a participation survey in which 50 samples were analysed

- Published data of National Rural Health Mission, Kerala for secondary data

- Propose to formulate new methods on the basis of Social Bond Theory to address the problem.

\section{Data collection}

- Sampling from public participation survey

- 50 data sample

- Secondary Sampling

- Collected data from National Rural Health Mission, Kerala

- Data collated from daily News Paper

\section{Analysis and Interpretation}

The ultimate goal of the Women empowerment campaign was for girls to enter employment after completing their higher education. Check the survey report on entering employment after technical education and seeing income.

Many women are seen to be becoming highly educated. Self-discovery of income also indicates this backward female uprising.

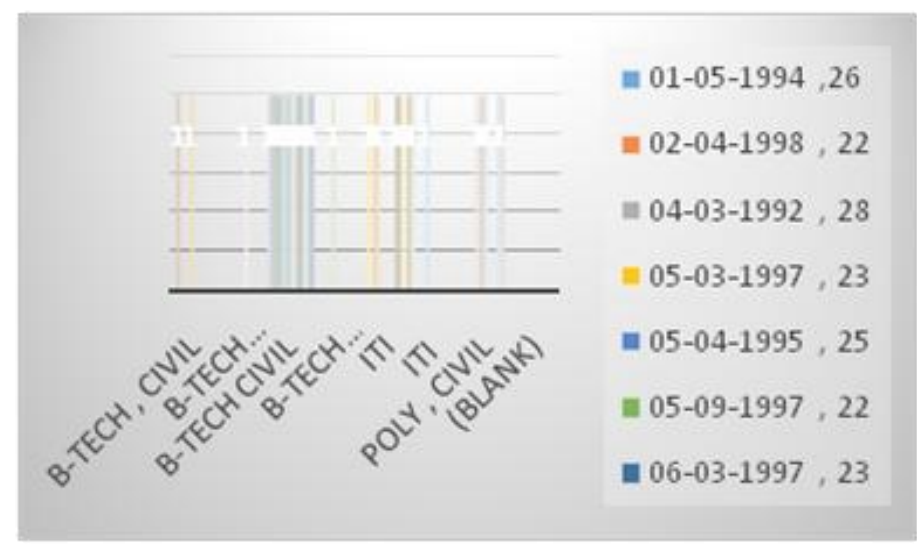

Figure 1 - Women Empowerment Educational Qualifications 


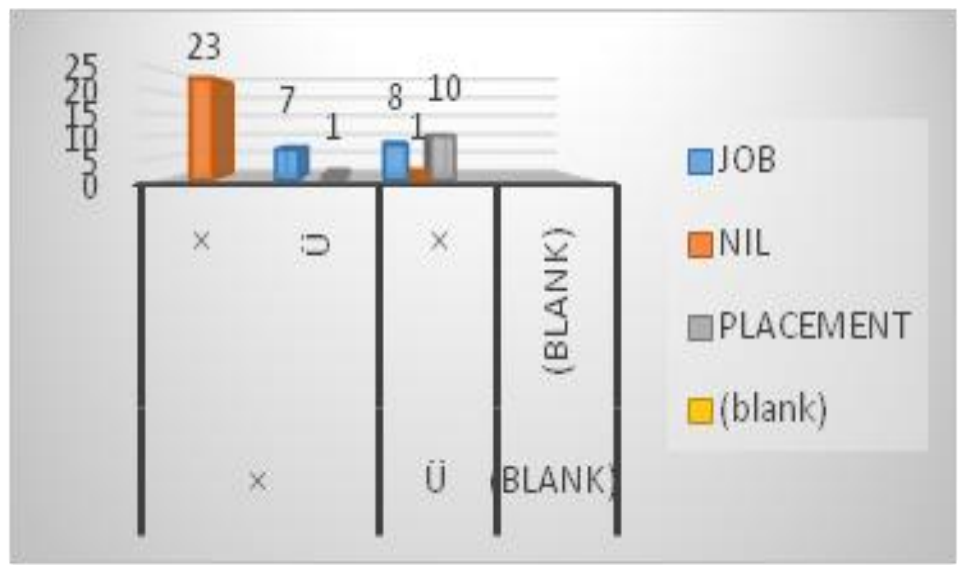

Figure 2 - Women Technical Education Survey

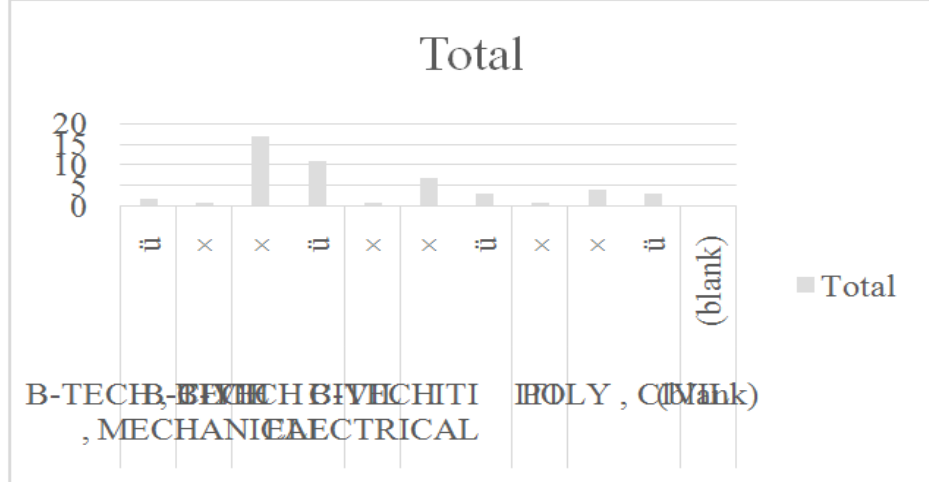

Figure 2 - Job attained charts

It is good for girls to be members of the Educational Empowerment Student Movements while they are studying.

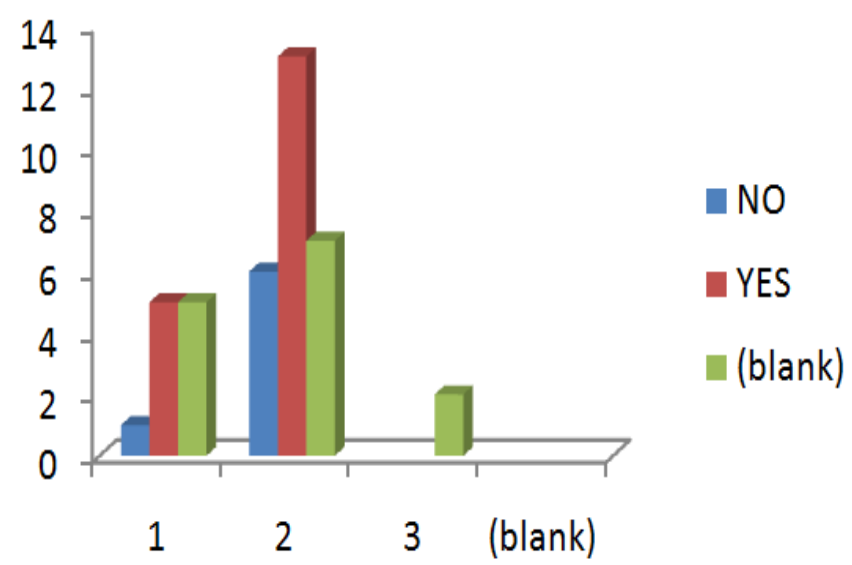

Figure 3 - Educational Students Movement Empowerment 


\begin{tabular}{|c|c|c|c|c|}
\hline $\begin{array}{c}\text { Count of Educational student's } \\
\text { movement's members? }\end{array}$ & $\begin{array}{l}\text { Column } \\
\text { Labels }\end{array}$ & & & \\
\hline Row Labels & NO & YES & (Blank) & $\begin{array}{c}\text { Grand } \\
\text { Total }\end{array}$ \\
\hline 1 & 1 & 5 & 5 & 11 \\
\hline 2 & 6 & 13 & 7 & 26 \\
\hline 3 & & & 2 & 2 \\
\hline \multicolumn{5}{|l|}{ (blank) } \\
\hline Grand Total & 7 & 18 & 14 & 39 \\
\hline
\end{tabular}

Figure 4 - Count of Educational student's movement's members

\section{Education}

As our country is on the path to a knowledge based society, the education of women is very important if the light of knowledge is not shed on the feminist power of our country and we will never be able to join the community of developed countries. Therefore, education, the most dynamic component of development, is an important tool for achieving empowerment and human resource development.

It illuminates employment opportunities and enhances economic empowerment for women. An economic well-being is associated with family well-being. Education gives the individual a conscience, which helps them to understand, interpret, critique, and ultimately transform their environment. It leads to the acquisition of a number of skills that increase a person's confidence and her ability to shape life in the best possible way. According to the World Population Report, "A mother's education is the most important factor in keeping her family young and children alive. Education is the first line of defense against life - threatening situations in which the traditional way of life exists. The International Conference on Population and Development Programs of the All-Right Action States in 1904 The Right to Education is the most important way to empower women with the knowledge, skills, and confidence needed to fully participate in the development process.

Education will go a long way in making women aware of their legal and personal rights and fighting for their rights, which will lead to the protection of her constitutional rights. Women's literacy is an important key to improving family health, nutrition and education and enabling women to participate in decision-making in society. It is an important tool for achieving the goals of equality development and peace. Therefore, the education of women should be given priority in the national agenda and mass illiteracy campaigns should be organized on a large scale. Empanel should be provided for the enrollment and retention of girls in formal formal and non-formal education through incentive schemes such as supply of lunch, supply of textbooks, uniforms, school bags, science kits, scholarships, accommodation, hostel facilities and removal. Gender bias in the curriculum. In addition, the government should open vocational guidance and career information cells in education administration units across the state. Special packages should be developed for tribal children in their local languages. It is good for girls to be members of the Educational Empowerment Student Movements while they are studying. 


\section{Result and Discussion}

In six elements for Women Empowerment

\section{Education}

- Compulsory education should be provided.

- Free education should be provided to all girls irrespective of caste or creed

- Children should be included in the political-secular education student movement during the study period.

- Provide arts and sports training.

- Teach agro-industries

- Provide technical education.

- Provide self-defense sports training.

- Provide special training for mental fitness.

- Provide career guidance during the study period.

- Other factors for further education in learning excellence Provide financial, physical, psychological and social factors.

\section{Elimination of Gender Discrimination.}

- Provide sex education during the study period.

- Provide special training to avoid falling victim to sexual violence.

- Provide counseling with children and family.

- Unwanted Conversation - Provide realistic detection training for sexual misconduct.

- Understand the useful aspects of the joint family lifestyle.

\section{Steps for implementation of Women Development Programme and various Acts}

- Provide technical education to all.

- Sow in your mind the ideas of becoming an entrepreneur during the study period. .

- Provide sports training.

- Discover creative topics and do special training activities for them.

- Understand the family situation and train them to work with the parent to support the family.

\section{Action for Organization of Awareness Programmes}

- Raise awareness on women's services

- Conduct training awareness on job achievements

- Raise awareness against drunkenness and follow the rules

- Female Scientology Raise awareness

- Understand Internet usage Raise awareness

\section{Rule of Mass Media}

- Understand the use / misuse of social media.

- Make safe use of the media for your own skill development.

- Understand services through social media. 


\section{Change the attitude of women}

- Attitudes can be changed through proper education and awareness.

- Make social norms worthwhile so that their own values are not harmed.

- Force them to seize opportunities to work equally with men in society.

\section{Conclusion}

There are a lot of things to think about when working in society for women's Empowerment. But it is about cultivating the core values for women to reach the mainstream of society. For that, the primary goal should be to provide education. During this early childhood education children should be trained for the mental preparation to reach the mainstream in the society. All that needs to be done is to provide platforms for people to express their talents for mental exhilarate. along with education. In this way, women can elevate themselves as leaders in society.

\section{References}

1. Saltazman LE, F. J. (1999). Centre for Diseses Control and Prevention. Atlanta: GA.

2. TKS(ed), R. (2000). Gender and Rights in Reproductive Health Organaization. WHO. Geniva: WHO.

3. TKS, R. (2000). Gender and Rights in Reproductive Health. p. 222. 


\title{
VIOLENCE AGAINST WOMEN AND COVID 19 PANDEMIC: A SYMBIOSIS
}

\author{
Mrs. K. Priyadarshini \\ Research Associate, Women's Studies Centre \\ Madurai Kamaraj University, Madurai
}

\section{Introduction}

The beginning of the year 2020 saw a virus out break named COVID 19 or Corona Virus. The countries in the world went for total lock down, considering the spread of the virus .The Director General of World Health Organization declared it as a pandemic on 11 th march 2020. Medical experts say that the Corona Virus Infectious Disease (COVID-19) spreads easily from one person to another the people were not allowed to go to public places like shopping malls, Temples, parks, tourist places etc. The people were asked to wear masks and wash their hands with hand sanitizers when they go out. The infected person's cough or sneeze can spread up to six feet if another person breathe them in he has high chances of getting infected by corona virus. Touching the object infected by the virus and then with the same hand rubbing the eyes leads to transmission of virus into the body. Research Studies on how many hours the Corona Virus can stay in various surfaces finds out the virus can stay four hours in copper, up to twenty four hours in cardboard surfaces and two to three days in plastic or stainless steel.

The spread of COVID19 turned the world upside down. It created huge economic crisis throughout the world. Economists say it might take it might take few years to make up with the loss due to COVID 19. Many people lost their job due to Corona virus and their survival is difficult.

The migrant labourers wanted to go their native places in the belief that they can make their living in their native places. Police men and doctors have endless duties day and night in protecting the public from corona. The Social service minded people are continuing their services to old people, people staying in streets etc like giving food and medicines to them. The folk artists do not have any programme due the corona virus and they started to giving awareness about the corona virus through singing and dancing in streets. The Educational institutions were closed and classes, examination were conducted through online mode. Amidst these situations in the society, the condition women who are the root for the society during Corona Virus is worse than before. The status of women is low in the society and they are in the control of men even though they are working equal to men, holding top managerial positions etc. We know that women are not safe due to yet another long lasting pandemic named violence against women. Violence against women is a human right violation. It is a universal issue which has impact not only on victims but also in their families and community. This chapter discusses the incidents of Violence against women both in International and Indian context, analyzes the reason for increased incidents on violence against women, and suggestions taken to reduce and tackle violence against women during the present situation where most of the countries are affected by COVID19. 


\section{International Scenario}

Violence against women is a violent act committed against women. Dr. Richters and J.M. Annemick(1994) in their book Women Culture and violence; a development health and human rights issue mention that Violence against women is "any act or threats of acts intended to hurt or make women suffer physically, sexually, or psychologically and which affect women as they are women or women affects women". Globally 243 million women and girls aged 1549 have been subjected to Sexual/ physical violence perpetuated by an intimate partner in the previous twelve months. On average, there are 433,648 victims (age 12 or older) of rape and sexual assault each year in the United States. ${ }^{1}$

The evidence that there are raise in incidents of Violence against women can be known from Newspapers, Calls to the help line numbers, Women rights activists and civil right partners. In France example the cases of domestic violence have increased by $30 \%$ since the lockdown from march17.2 The News was given to the Euro News by the France Interior Minister Christophe Castaner revealed on Thursday that in Paris alone, were up by 36\% and cases on Domestic violence across the country have jumped by more than $30 \%$ since the country went into lockdown on March 17th. The minister further said that the France already has one of the highest rates of domestic violence in Europe. Every year, an estimated 219,000 women, aged 18 to 75, face physical or sexual violence by current or former partners, but only $20 \%$ report it. According to official figures, one woman is killed by a partner or former partner every three days. Help lines in Cyprus and Singapore ${ }^{3}$ have registered an increase in calls by $30 \%$ and 33\% respectively. The Edition says that the epidemic has had a huge impact on domestic violence throughout the world and the calls through help lines though it is increasing we cannot consider that all cases on Domestic violence are brought to the notice and registered. Many women are not coming forward to make complaints as they may have restrictions and in the time of Lockdown it is difficult for women to make complaints on violent acts and get help from support services provided to them.

The New south Wales Survey on Women Safety Conducted in Australia found out that 40\% of the frontline workers (Workers who directly deal with the customers) in the women service centre have increased requests for help by survivors. Further $70 \%$ of the frontline workers in the centre said that the cases received by them are more complex in nature than the cases received by them before lockdown ${ }^{4}$ due to COVID 19.0n the other side in Italy a Domestic Violence Helpline reported that the calls received by them is reduced by $55 \%$.The reason that the women activists say that many women would have trouble in contacting the help line numbers. The Statistics reveals that the COVID 19 is making the condition of women worse than before. Though there are raise in complaints to helplines it cannot be said that the total cases of violence against women is registered as on the other side we have evidence that the calls to the help lines are reduced by 55 percent. Women in the west are struggling to reach

\footnotetext{
Department of Justice, Office of Justice Programs, Bureau of Justice Statistics, National Crime Victimization Survey, 2018 (2019).

2 Euro news on the title "Domestic Violence cases jump 30\% during Lock down in France" dated 28.03.2020

3 The Guardian Newspaper Edition on the title "Lockdowns around the world bring rise in domestic violence" dated 28.03.2020

4 "Domestic violence spikes during corona virus as families trapped at home "https://10daily.com.au/news/australia/a200326zykh/
} 
the helplines. The cases of violence against women is already on the raise and the lock downs of Covid 19 helps to increase the cases of Violence against Women. It is also clearly known that women who are working for the upliftment of other women face a difficult situation in the time of COVID 19.

\section{The Indian Scenario}

In India Violence against Women is used as a weapon by men to control women and establish his power. As per the data of National Crime Records Bureau (NCRB).a total of 89,097 cases related to crimes against women was registered across India in 2018. The figures indicate not much has improved when compared to the figure of 86,001 cases registered under this head in 2017. The crime rate per lakh women population is 58.8 in 2018 in comparison to 57.9 in 2017. According to data from the 'Crimes in India - 2018' report compiled by the National Crime Records Bureau (NCRB).Domestic violence against women figures as the top category of violence against women in 2018. The cases registered under the 'cruelty by husband or his relatives' are 31.9 per cent. The cases registered under the 'assault on women with intent to outrage her modesty' are 27.6 per cent. ${ }^{5}$ The cases under 'kidnapping and abduction of women are 22.5 per cent and the rape cases registered were 10.3 per cent. The data of NFHS(National Family Health Survey) also show that there is not any reduction in the cases of domestic violence from the year 2006 and the survey in the year 2015-16 revealed that $52 \%$ of the surveyed women and $42 \%$ of the surveyed men think that there is one valid reason for wife beating 6 . In India the cases on Domestic Violence is high for more than ten years and the revealing of the survey tells that the Indian society has trained the minds of the women in such a way that it goes along with male, accept that male ideas are correct (nothing wrong in a male beating a women) obliges him and cannot act individually without him.

The news shared by the National Commission of Women(NCW) to the Hindu is its launch of domestic violence help line number. Mrs Rekha Sharma told the Hindu that the total complaints received from women rose from 116 in the first week of March (march 2 to8) to 257 in the final week of March(march 23-april 1).While cases of domestic violence have increased from 30-69. There has been a threefold increase in police apathy(not taking complaints seriously) towards women's complaints as the police are busy enforcing the lockdown to curb the spread of COVID 197. The National commission has launched a help line number -0721-7735372 to enable those facing domestic violence to send a whatsapp message to access help as NCW recorded more than a two fold increase in Domestic violence and Sexual Assault In the time of COVID198. Earlier the NCW was accepting complaints from women directly or through e mails.. In the month of april the National Commission of women shared the data to The Hindu saying that 123 cases of domestic were received by the commission between February 27 to march 22.In the last 25 days the commission has received 239 more such complaints. Since the Lockdown declared by the prime minister on March 24 to control the spread of Corona Virus and from February 27 to March 22 a total of 396 offences related to women were reported to NCW ,while from March 23 to April 16 as many as 587 such

The National Herald E News on the title Domestic violence tops crime against women in 2018: NCRB Akshaya Vijaya Lakshmi\& Pritha Devi in The Hindu -OPED dated April 92020

The Hindu Dated April 22020 on the title "Covid 19lockdown/Rise in Domestic Violence,police apathy : NCW The Hindu Dated april 102020 on the title"NCW Launches domestic violence" 
complaints were received. The chairman of the commission said that from the launch of the Help line whats app number a total of 40 messages was received reporting domestic violence ${ }^{9}$. In the series of press release to the Hindu by the NCW it is clearly proved that there are increase in the complaints from women related to abuse and other forms of violence against women. The NCW on noticing the increase in cases of violence against women has launched the help line number so that women throughout the country can get help as women know to whats app text now days. It is alarming to see the data within a period of 20 days in the month of February to march 396 cases was registered i.e. previous month of Lock down the complaints by women has doubled in the first month of lock down (596 cases).This gives us a picture that the cases against women are high and corona virus is having an impact on violence against women.

\section{The Impact of COVID 19 on Violence against Women}

Generally women are not safe during Covid 19 as they can be easily kidnapped, raped, sexually harassed etc. The reason the streets would be empty as movement of the people are restricted in lockdown time. Police officials will be busy in controlling the pubic in main places in the city or village. In what other ways COVID 19 has its impact on Violence against Women is given below

- Alcoholism/Usage of Drugs and DVAW (Domestic Violence Against Women): The habit of drinking Alcohol / usage of drugs would increase in the time of COVID 19 as many would have lost their jobs or facing economic crisis which causes high level of drinking Alcohol and more usage of drugs and leads to wife beating or other incidents of Domestic violence against women.

- Work place violence especially the health workers : The Doctors ,Nurses and other health workers who have to work all day to save the public are highly affected or could be said as the first targets for the perpetrators of violence against women as they are the one to deal more with the public in the time of Pandemic.

- Increased risk of Violence Against through online: Today many are asked to work at home through online mode and women are at a great risk as they may have chances to be threatened through online pornography and other types of online threats.

- Less contact to family and Friends: Women may have less contact with family and friends who will give suggestions, moral support and protection from women during the lock down period.

- Limited access to health services: In the time of COVID 19 the health workers would be already burdened in working towards eradicating the pandemic so the other type of health services especially for women like treating a victim of violence against women or giving counseling to the victim is impossible or minimal.

- Increased risk for women in refugee camps/women shelter for victims of violence against women: Women staying in refugee camps and women who are already victims of violence against women staying in shelter for destitute women are having high risk of being sexually harassed and other forms of violent acts against them.

9 The Hindu Dated April 172020 on the title "Corona Virus lockdown/India Witnesses Steep rise in crime against Women, 587 complaints received says NCW. 
- Economic crisis and abuse of women: Everyone would be facing economic problems money would not be there to buy basic things, much chaos, confusions and stress due to economic crisis which leads conflicts and violence towards women. Due to minimal resources women may be experiencing economic abuse.

\section{Conclusion}

Studies show that and we also observe women are the vulnerable group when society faces a problem. Priority should be on ensuring Safety and security women during the times of pandemic. Strengthening and allocating services for women during COVID 19.More people can be allocated for giving services to victim of violence against women on psychosocial support, emergency shelters. Women experts, grass root organization that works for women must be involved in decision making process of recovery plans and the long term plans in the time of COVID 19.Seperate funds for women during COVID 19 must be allocated. Spreading awareness about violence against women and what are the support services available for them during COVID 19 through media is must so that women can know the services available for them. More Research should be conducted on raising incidents of violence against women during the pandemic. The support services should be easily approachable during the pandemic situation. All the stakeholders, Policy makers Government and Non Governmental Organization should join together in working towards tackling both the pandemic named violence against women and Covid 19.

\section{References}

1. Department of Justice, Office of Justice Programs, Bureau of Justice Statistics, National Crime Victimization Survey, 2018 (2019)

2. Pamela Abbot, Claire Wallace and Melissa Tyler, An Introduction to Sociology feminist perspectives, Routledge publication, London and Newyork,1990.

3. Euro news on the title "Domestic Violence cases jump 30\% during Lock down in France" dated 28.03.2020

4. The Guardian Newspaper Edition on the title "Lockdowns around the world bring rise in domestic violence" dated 28.03.2020

5. "Domestic violence spikes during corona virus as families trapped at home "https://10daily.com.au/news/australia/a200326zykh/

6. The Hindu Dated April 22020 on the title " COVID 19 lockdown/Rise in Domestic Violence,police apathy : NCW

7. The Hindu Dated April 102020 on the title "NCW Launches domestic violence"

8. The Hindu Dated April 172020 on the title "Corona Virus lockdown/India Witnesses Steep rise in crime against Women, 587 complaints received says NCW.

9. Nikhil Kumar Singh \& Sandeepa, Violence against women in India; international journal of research and development in technology and management science, Volume 21; Issue 3 June 2014/isbn1-63102-44 


\title{
THE CRITICAL ROLE OF MASS MEDIA DURING COVID-19 PANDEMIC
}

\author{
Dr. T. Subhashini \\ Assistant Professor of Education Home Science \\ Lady Willingdon Institute of Advanced Study in Education, Chennai
}

\begin{abstract}
Corona virus disease 2019 (covid-19) is first reported in china and spread worldwide to become a global pandemic. Throughout the world all government followed social distancing and isolation measures to reduce the risks. It paved way for the self-quarantine and isolation which affects the mental health of the people. Since no one knows about the correct information we ought to obtain it from an authentic source. Media works as the bridge between government and the society. Media is the powerful agent, where a viewer or a reader, just close our mind and open our eyes. During this crisis period, media played a very significant role in making the public aware about the situation, calm the junta and encourage them to do positive action. Various kind of digital and printed media plays their important role. The impact they presented have been highlighted in this paper. There are many challenges faced by the people especially women population across the nation also discussed here. Therefore the objective of the paper is to find the critical role of mass media during covid-19.
\end{abstract}

Keywords: Types of Mass Media, Mass Communication, Technological Tools, Covid- 19, Coronavirus, Pandemics.

\section{Introduction}

Mass media reports on a pandemic can provide important information about various aspects. Presently Corona virus disease pandemic has produced a global health crisis that has had a deep impact on the way we perceive our world and everyday lives.

\section{Role of mass media during pandemic}

The covid-19 pandemic has generated a lot of media coverage. These have been conflicting reports on the effectiveness of lockdowns, social distancing and masks.

They gave awareness about

- The spread rate of contagion

- The patterns of transmission

- The safety measures about the virus

- The safety measures about the spread

- The importance of social distancing

During the crisis, lack of awareness, knowledge and preparedness would put people and health care staff at risk. The dilemma is how to pass the knowledge of current information and prevention to the general population. Same time, a huge amount of health-threatening misinformation is spreading at a faster rate rather than the disease itself. Though social media only this dissemination offalse rumor occurs. Thus delivering fast, accurate and reliable information is very very important. If we use social media properly or wisely, definitely it will serve as a powerful tool for changing people's behavior and promote individual and public 
health. During sudden out breaks, the public needs access to timely and reliable information about the disease symptoms.

The 2019 novel corona virus disease is currently the disorder with the greatest social impact, due to several factors, including associated deaths, its geographical expansions, stock exchange fall worldwide, cancellation of various events, shortage of goods in market place etc.., that in turn related to the behavior of societies at different level.

In this contest the media must have social responsibility to keep the population properly informed. Media always provide adequate information on this issues which are understandable and clear. Mass media is the technology used to reach a mass audience. The types of mass media are the newspaper, radio, magazines, internet and television. Printed media are newspapers and magazines and the broadcast media are TV, and radio.

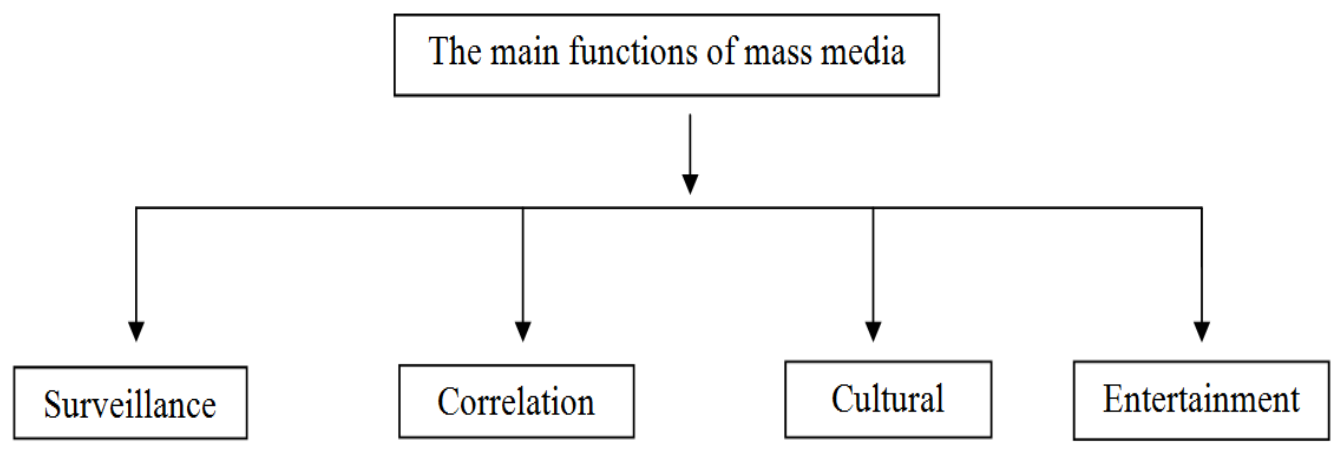

Mass media is used to inform individuals regarding diseases within a population. Attention to health news has been increasing in importance during the last few decades, and thus media reports can play an important role in defining health issues, since they serve as a major source of information and are able to incite changes in behavior in the public.

The Covid - 19 crisis is a global challenge. As border close, researchers are working together to understand the scope of trajectory of the pandemic, identity measures to prevent virus. Our working environment has changed. Many of them are working from home. Many are unable to continue carrying out their previous work. Some are responsible for supporting their children and some are supporting family members. We are all learning how to be resilient to balance the real personal challenges that this current crisis creates with the needs of carrying out work.

Social media is a powerful tool to communicate to the outside world about struggles faced by the members and people in our communities with the advent if social media in the $21^{\text {st }}$ century, not only are we learning the latest news updates be we are also using platforms like facebook and twitter.

\section{Four primary roles of social media during covid-19}

- A source of information

- An influence in public response to the outbreak

- A marketing platform

- A powerful way to bring positivity to a scary time 
In the history of human growth and development the 'covid' infection is not known to the people, similarly in the animals of medical fields also. The endangering virus was not known to the people. It is said that it was identified and started causing deaths in chain where more than 1lakh people were died within in the period of few weeks. Afterwards it has been started to spread in large number of countries in the world.

The role of the mass media is highly important to all people. That is the individual, family, community and country at large. The media organization has to popularize and conduct programs of information, education and communication to the people as a priority program using multimedia approach and activities. The journalists of the media institution may happen to dedicate themselves to participate in life saving miracular service to the people of the country.

Media persons have to collect information and data from various professionals like medical professionals, scientists, government officers and authorities of that area. Analyze and arrange plan for various kinds of program to reach the people and especially the affected persons and families. Whatever information collected, it should be truthful, relevant and from credible sources.

The investigating information methods to be acquired through interview, discussion, dialogue from the concerned person or authority. Such a way the collected data of information must be treated to reach the people of the area and relevant to the customs and exciting social systems and norms. In a democratic country like India the journalists of the media and investigators must be free from bias of any kind and committed to the cause for which they works. Sometimes they may happen to work around the clock and follow the norms of the institution.

The primary function of health communication is to provide scientific knowledge about the infection to the people. The people are heterogeneous by birth, socially, economically and politically. Specifically the covid infection causes illness and deaths. The people's cultured values, beliefs and their norms are different. So the media program required to be designed for people to reach them and awaken their interest and action. During this process, the mass media educational activities can play a key role. Information, education, communication and motivation through proper channel and relevant processing will contribute indirectly to bring reduction of covid infection. All peripheral level services and coordinated hospital services will make alleviating the condition and the existing trend of covid problem.

Mass media institutions establish coordination through this Medias

Print media, Electronic media, (Radio, television.)

- Prepare handouts and distribute to people/leaders

- Follow precaution measures:

1. Wash hands with soap and water

2. Use mask

3. Stay in home

4. Avoid social contact

5. Drink kapasura kudineer

- Involve:

1. Women groups

2. Local leaders 
3. Unemployed youths

4. Panchayat leaders

5. Farmers sangam

- Organize debates for school children

1. Mass media platform plays a crucial role in providing information regarding the coronavirus. Since little is known about COVID-19, various fake news, misinformation and resources spread across the digital media that panicked people into making panic decisions. The rapid spread of misinformation and stories via social media platforms such as twitter, face book and you tube become a vital concern of the government. This misinformation and fake news creates panic, fear and anxiety among people and affects their mental health conditions especially the women population particularly pregnant and aged women.

\section{Impact of mass media during pandemic}

Twitter has the potential to provide real time content analysis which makes the authorities to answer the queries quickly. When inaccurate or false information passes on to the public, they tend to panic and respond to such misinformation in several ways, which include making a panic purchase and trying out excessive or even harmful drug regimens.

Misinformation on FACEBOOK about possible medicine like hydroxychlorine to treat covid-19 motivated people to buy such medicines without medical approval, resulting causes inadequacy of medicals to the needy population.

Infodemiology is aimed at educating public health agencies and designed public policies to evaluate electronically created data. The benefit of infodemiology is its ability to collect health-related data in real-time from unstructured, written, picture or user-generated information that is shared through digital media such as websites, blogs, and social network sites

Cyberchondria and information overload were observed from excessive internet use during COVID-19 pandemic. Cyberchondria is characterised as obsessive online searching for information related to health, usually about specific symptoms. Information overlo ad is a situation in which all communications and information inputs cannot be processed, resulting in the process of gathering information being terminated or the whole process becoming ineffective.

Teachers can also use Instagram to help students. You can post homework and project reminders, as well as post picture-by-picture tutorials. Instagram is also a great way to encourage classroom discussion through the comments section and ways for students ask for the help they need. Instagram is an entirely visual platform. Unlike Facebook, which relies on both text and pictures, or Twitter, which relies on text alone, Instagram's sole purpose is to enable users to share images or videos with their audience.

The COVID-19-led lockdowns brought production, manufacturing, buying, and selling to a grinding halt. In these unprecedented times, small businesses need to pivot to persist. With the internet being sometimes the sole and most effective medium for communication, businesses are using the power of social media to come up with innovative solutions, to pivot - and survive. 
The Future of Business Report, collaboration between Face book, the World Bank, and the Organisation for Economic Co-operation and Development (OECD) to survey millions of small businesses on Face book around the world, found 18 percent of people identifying as owners or managers of businesses on Face book are women.

During the lockdown, many women-led businesses continued to scale and engage on the platform using it for customer acquisition, staying connected with existing customers, reaching new consumers, and interacting with like-minded businesses in the SMB ecosystem.

Her Story spoke to three women entrepreneurs, who are innovating to keep their businesses up and running during the pandemic, and how they have used Facebook and Instagram to understand the changing needs of customers.

\section{Role of women in mass media during COVID pandemic}

Communication is exceptionally vital for women's development and mass media renders a significant contribution. In all subjects of life whether for controlling of various societal problems, spread of literacy or improving excellence of life women have a role to play. For their awareness and improvement media has been significant part, that is to generate consciousness in women to attain the prospective as the prime transporters of changes and modifications within the social setting.

In the presence existence, print and electronic media play an essential part in efficiently communicating a message that needs to spread to masses. The researchers on the basis of online survey and media reports that emerging studies into Covid-19 together with lessons from past outbreaks suggest that the pandemic could have profound and potentially long-term impacts on psychological health, economic, social and religious life. Rapid and rigorous research accessing the impact of Covid-19 on psychological health of people is needed to limit the impact of the pandemic. The present pandemic is clearly having a major social and psychological impact on the whole population, increasing unemployment, separating families and various other changes which are generally considered as major psychological risk factors for anxiety, depression and self-harm.

\section{Conclusion}

Since the announcement of COVID-19 as a pandemic, the mass media has been flooded with information. Some information is to educate people about the new virus. On the other hand, misinformation regarding the pandemic and treatment lead to fear, anger and panic. The Government bodies and public health care workers utilized the media in teaching awareness among the people. The government has used social media in informing the people about the current updates, thus resources being utilized. Thus the media also ensure the accuracy of information.

\section{References}

1. Hussain Wajahat. Role of Social Media in COVID-19 Pandemic. The International Journal of Frontier Sciences, vol.4, no.2, 2020, pp-20-25.

2. Mangal, S.K, and Mangal Uma. Essentials of Educational Technology. PHI. 2011. 


\section{Web References}

1. https://www.who.int/emergencies/diseases/novel-coronavirus-2019/question-andanswers-hub/q-a-detail/q-a-coronaviruses

2. https://www.mygov.in/covid-19

3. https://www.frontiersin.org/research-topics/13638/coronavirus-disease-covid-19the-impact-and-role-of-mass-media-during-the-pandemic

4. https://www.weforum.org/agenda/2020/04/covid-19-media-value/

5. https://www.id-hub.com/2020/03/05/role-can-media-play-managing-covid-19outbreak/

6. https://www.dw.com/en/global-media-forum-tackles-role-of-media-in-covid-19reporting/a-53934262 


\title{
ENTREPRENEURS IN THE PATH OF COVID
}

\author{
Mr. N. Jegatheesan M.Com., B.L. \\ Research Scholar, Department of Commerce \\ Madurai Kamaraj University, Madurai
}

Every crisis brings challenges and threats to entrepreneurs and their organizations, no matter if initiated by human behaviour, natural disasters or economic mechanisms. At the end of December 2019, the coronavirus (so-called COVID-19) has started spreading from Wuhan, China to other countries so widely and quickly, that on 11th March 2020, World Health Organization - WHO (2020) declared COVID-19 pandemic. As a response to mitigate coronavirus spread and save lives, governments in affected countries imposed desperate measures of social distancing, widespread lockdown, restrictions on travelling, movement, and people gatherings. Many aspects of private and public life had to be moved online. Entrepreneurs were not an exception. They had to start moving their business activities online. However, not everything could be solved conveniently online. COVID-19 has significantly influenced the entrepreneurial engagement of self-employed persons. Some entrepreneurs had to close their businesses temporarily as a result of governmental restrictions; others had to impose precautions and to run their activities in reduced extent. They also needed to find innovative solutions in all aspects of their entrepreneurial endeavour as the consequences of the pandemic linger on. It took time before the entrepreneurs got oriented in the new situation, and governments started helping them out with particular policy-actions aiming to deliver information, advisory and financial support. Pandemics will very likely influence traditional entrepreneurial decision-making processes, communication and conflict management, well-being and entrepreneurial outcomes.

In the face of the global COVID-19 pandemic, entrepreneurs have to face a new reality: that it is not only a huge sanitary and health crisis affecting millions, or even billions, of people across the world. This is also provoking an unprecedented downturn in the global economy.

\section{Impact of Covid on Business Path}

In India, out of the total population, 30 Percentage of the total population comprises of people who belong to the High income group, Government employees, Teaching faculties and the middle income group of people who has surplus savings and the remaining 70 Percentage of the total comprises of the people who does not have any money flow in this pandemic. There is no schemes for the suffering people from both Central and State government. 


\section{Business Cycle}

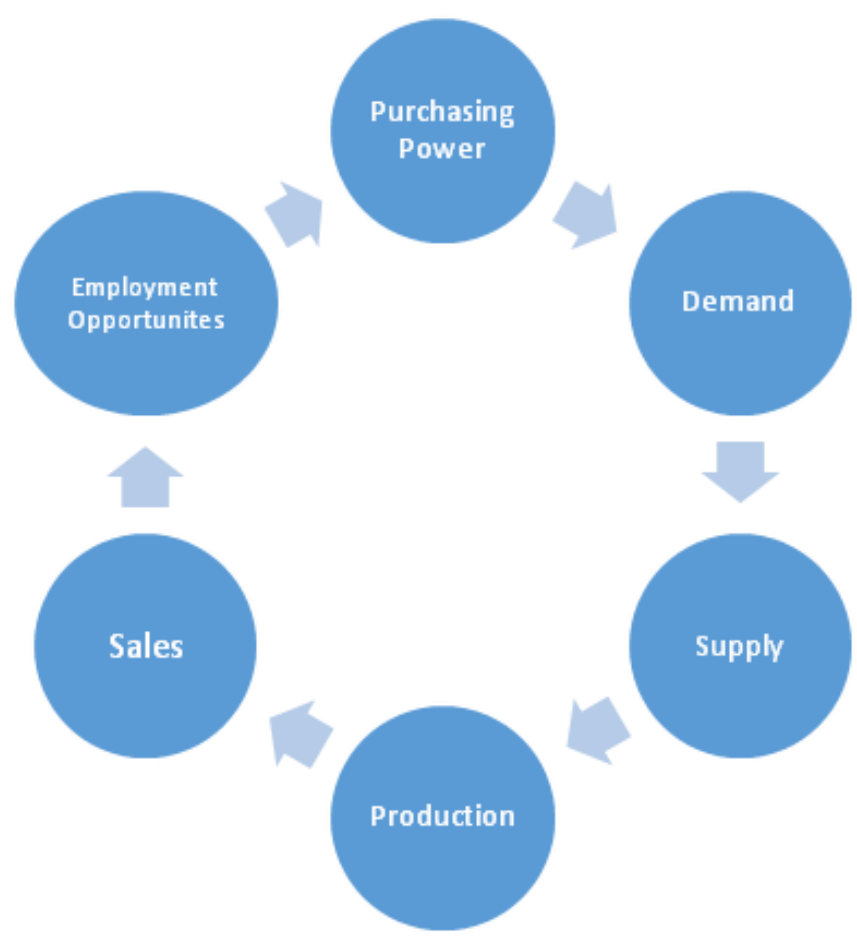

From the above figure it can be inferred that when the purchasing power of the consumer increases, the demand of the product raises which in turn increase the supply of the raw materials. With the adequate raw materials more products can be produced and leads to high turnover with profitability which also created more employment opportunities but this COVID -19 have ceased the cycle.

\section{Trade and Business after lock down}

In trade and business even after lock down there is only $10-20$ Percentage of sales and even there is no breakeven sales for many traders. According to the MSME Ministry's FY19 annual report, the MSME sector is dominated by micro-enterprises. India has 6.33 crore MSMEs out of which 6.30 crore -- 99.4 Percentage are micro-enterprises. In this pandemic out of the total MSME industries in Tamilnadu 35 Percentage of the industries have withdrawn their capital and become sick during the lockdown period.

According to All India Manufacturers' Organisation (AIMO), About 35\% of micro, small and medium enterprises and $37 \%$ of self-employed individuals have started shutting their businesses, they have also pointed that there is no chance of a recovery in the wake of the Covid outbreak. The government's financial package has not reached the MSMEs and is also not adequate to make up for the loss of business activity during the lockdown period. This sector not only seen many closures but also seen many people losing their employment opportunities, scaling down of operations, focus on core business and a fine financial balancing act. Most in Micro enterprises, many entrepreneurs have closed their business and seeking job opportunities for their survival. 


\section{MSME}

In India, MSME industries contribute 30 percentage of GDP from manufacturing and service activities with 33 percentage of total country's manufacturing output. This industry is having been able to provide employment to around 120 million persons and contribute around 48 percentage of the overall exports from India. About 20\% of the MSMEs are based out of rural areas, which indicate the deployment of significant rural workforce in the MSME sector and is an exhibit to the importance of these enterprises in promoting sustainable and inclusive development as well as generating large scale employment, especially in the rural areas.

The MSME sector contributes in a significant way to the growth of the Indian economy and its units is often considered as the backbone of the nation. It had a share of 233 crore of India's total GDP and the share of the sector in total manufacturing output was even higher at 45 percent.

\section{Atamanirbhar Bharat}

To provide relief to millions of small businesses reeling under the impact of the Covid-19 lockdown, Honourable Finance Minister Nirmala Sitharaman announced a slew of liquidity measures, which include collateral-free automatic loan worth Rs 3-lakh crore. Borrowers with up to Rs 25 crore outstanding and Rs 100 crore turnover are eligible.

India has demonstrated how it rises up to challenges and uncovers opportunities therein, as manifested in the re-purposing of various industries to collaborate in the making of products in this pandemic. "Atamanirbhar Bharat" package totalling Rs.20 lakh crore was elaborated over the five phases. The five phases are

- Phase-I: Businesses including MSMEs

- Phase-II: Poor, including migrants and farmers

- Phase-III: Agriculture

- Phase-IV: New Horizons of Growth

- Phase-V: Government Reforms and Enablers

\section{Emergency Credit}

Businesses/MSMEs have been badly hit due to COVID - 19 need additional funding to meet operational liabilities built up, buy raw material and restart business. Emergency Credit Line is provided to Businesses / MSMEs from Banks and NBFCs up to 20\% of entire outstanding credit as on 29.2.2020. Borrowers with up to Rs. 25 crore outstanding and Rs. 100 crore turnover are eligible. Loans to have 4 year tenor with moratorium of 12 months on Principal repayment but this scheme is not useful for various MSMEs. The industry which does not have obtained any loan so far would be benefited with this scheme. The cut-off date will be a burden for the seasonal business units and obtaining additional loan will be affected.

For example In Sivakasi, Fireworks units will make sales of crackers in the month of Diwali (October), the settlements will be made and in the month of December the balance will be nil and the same in the case of units preparing calendars and dairies the sales and the settlements will be made in the month of January itself and will have nil balance since these industries have nil balance on February, the loan provided on the outstanding credit will be rejected to these industries. 
Repo rate means the rate at which theReserve Bank of India lends money to commercial banks in the event of any shortfall of funds. At present the Repo rate of the bank is four percentage, the commercial bank if they provide the loan at $5-6$ percentage it will be benefited to the borrowers but the commercial banks provide the loan at an interest rate of 9.25 percentage which in turn makes the business units to lose its hope and there arises a hypothetical question on the development of MSMEs in India.

\section{Relaxation in Law}

In Uttar Pradesh, thirty labour act governing the respective trades is suspended for three years to motivate the trade industries without any hindrances. Relaxation has been provided in the Factories Act and Labour law in U.P, Himachal, Madhya Pradesh and Rajasthan states. In these states shifts have been extended and over time are also permitted. The shops and establishments is permitted from morning 6 a.m. to mid night 12 a.m. to do business. This relaxation is provided to trade and business units in order to boost up their production and sales in this pandemic situation. This relaxation has not been provided in Tamil Nadu.

\section{Electricity}

There are two tensions in electricity, the usage upto 112 KVA is low tension and the usage more than $112 \mathrm{KVA}$ is high tension. 90 percentage fixed demand charges will be levied ( $1 \mathrm{KVA}=$ Rs.350) for example in case of $1000 \mathrm{KVA}, 90 \%$ of which is $900 \mathrm{KVA}$ and the total fixed demand charges will be calculated as Rs.3,15,000 (900 KVA x Rs.350). The fixed demand charges should be paid even if there is no operation.

In this lockdown the Hotels, Wedding Halls, Shopping Malls, Cinema Theatres and 50 percentage of MSME industries does not operates but they are asked to pay the fixed demand charges which forms as the burden to the entrepreneurs.

A case was filed against this fixed demand charges and the Tamil Nadu Electricity Regulatory Commission (TNERC) on May 4, 2020, passed on order instructing TANGEDCO to collect only 20 per cent of the sanctioned fixed demand charges for lockdown period instead of 90 per cent. TANGEDCO applied a case in the Electricity Tribunal and got the stay to the orders passed by TNERC on 18.5.2020. Now the business units are paying 90 per cent as Fixed demand charges and there is a threat that if the charges are not paid the connection will be disconnected. This is also another hindrance of the entrepreneurs in this pandemic situation.

Business units have faced many problems in recent years first is demonetarisation which was a great failure and second one is GST implementation. The GST was a good taxation but the implementation and the tax rate structure is still in confusion stage so far 200 amendments have made. In this pandemic period the trade bodies can been tax relaxation of tax rate cut off for a particular period.

No amendments in taxation, No Bank finance, No Government support to the trade and business. To fly from the cage of COVID - 19, it takes time. 


\title{
ROLE OF FEMINISM IN WOMEN EMPOWERMENT DURING PANDEMIC THROUGH LITERARY CHARACTERS
}

\author{
Dr. S. Udhayakumar \\ Assistant Professor, Department of English and Comparative Literature \\ School of English and Foreign Languages, Madurai Kamaraj University, Madurai
}

\begin{abstract}
The need for a stimulus to empower women in today's global requirement is indispensable due to the inevitable changes that are happening in various domains. Empowerment in the context of social, education, economic, political, and psychology will instigate the effective participation of women in the development of the human community as a whole in fighting global issues. Being half the population of the world, women when fail to contribute their part, a quick holistic development can't be achieved. Hence, during difficult circumstances like a pandemic, the active submission of women's potentials would be a strong backbone in maintaining the status quo of the family and society. This paper argues that how feminism works as a guiding star of women to face the wrecking condition that the whole world is facing now. It further argues whether feminism would function as damage control to the falling economy, joblessness, poor health care, and whether it would infuse women with a new spirit of enlightenment to face the new world challenges after the end of this Pandemic.
\end{abstract}

Keywords: Feminism, Pandemic, Oppression, Liberation, Four Waves, Domestic, Beatrice, Alice, Ruminating

The Role of Feminism from the past to the present in empowering women has achieved success to a greater extent. Starting from Marry Wollstonecraft's A Vindication of the Rights of Women (1792), to the present day reformation in feminism has been the pillar support of the present-day women. This evolution has been classified into four waves. All the four waves of feminism have waved the sun to rise in the lives of women to shine bright at their family level, institutional level, and social level. Now and then, some thorns and obstacles arise in the path of women empowerment. Feminism with different lenses looks upon those issues carefully and brings remedies. From the past till now, there have been different degrees of problems encountered by feminism on sexism, no rights in education, sexual abuse, and many. These issues have been handled and observed using various viewpoints like Liberal Feminism, Radical Feminism, Marxist Feminism, Black feminism, Native American Feminism, Existential Feminism, Multicultural Feminism, Eco Feminism, Postmodern Feminism and many. Despite all these isms, many women are still lacking power, leadership, and safety in their families, institutions, and society which are much visible through the ordinary glance in our day to day transactions. In a way, Feminism keeps finding solutions for every emerging issue. One such emerging issue is pandemic which has plunged all over the world and is disturbing the normalcy of life in recent times.

To tell about Feminism, it is a movement formed during the late nineteenth-century theorizing and contesting different political activism in bringing justice and equality to women. Toril Moi differentiates the nomenclature of feminism in three connotations that are, feminist, female, and feminine. Feminist is used in a political context, the female is used as a 
biological term and feminine is viewed as a characteristic of culture. The fact is that in all three contexts women face challenges. This is why; the word feminism has to be understood in different magnitudes based on their use and context. In general, Feminism is simply against sexism but, the idea of Feminism is very much complex to understand that it transacts with different areas like culture, social, sexual, psychology, should be considered. Moreover, these issues vary from place to place, culture to culture, and time to time. Hence Feminism finds why, when, where, and how women are oppressed. It is not only women voicing for them but also male counterparts has extended their support, like D.H. Lawrence, John Stuart Mill, etc. Frederick Douglass and a former slave have argued on behalf of women in one of the 11 resolutions as a radical demand in the first women right convention held in 1848 "For the overthrowing of the monopoly of the pulpit, and for the securing to woman an equal participation with men in the various trades, professions, and commerce."

Feminism is working since women are not able to express their problems and feelings. It is a political movement that brought a revolution first in the USA and Europe. And to date, it ponders towards each minute issue that women suffer for. Hence, the need for feminism is obligatory. As Zara Huda Faris says, "Women need feminism because there are women who suffer injustice". However, Injustice to women from the past to the present is being limited gradually with the help of feminism. These gradual growths in women's liberation can be studied only by knowing the history of feminism. The history of feminism is studied upon its three waves of evolution. Frances Power Cobbe, an Irish Activist points out about this movement that "resembles the tides of the ocean, where each wave obeys one more uniform impetus and carries the waters onward and upward along the shore". As he mentions, "feminism has its wave taking the prime responsibility in reaching solutions to women issues across the time very effectively."

First-wave feminism stands in protecting the basic rights of women. That came during the 19th and early 20th century in the western countries. Its prime focus was on legal issues; the American Equal Rights Association in 1866 fetched voting rights to women. It is the time when women are seen as the property of father or husband; they don't even have the liberty to file divorce and take custody of their children. However, women enjoyed basic rights after the first wave.

Second-wave feminism started in the early 1960s to 1990s. It came to beat the public and private injustices on women. During the time, most of the men involved in warfare. Since the majority of the men worked in defense forces, women had to take care of their family and so they started to go for work. But when the forces returned these women had been dismissed from their jobs or otherwise they had been limited to jobs like teachers, nurses etc. Hence, the movement raised these issues and added a few more issues to it like rape, reproductive rights, domestic violence, and workplace safety, etc. It further ensured these rights to them. National Organization for women and the Civil Rights Act of 1964 are the notable events of this period.

Third-wave feminism came after the 1990s. It incorporates postcolonial and postmodern ideologies. Since the first two waves focused on legal rights and their protection, the thirdwave looked upon the women's getting economic and professional power and status. This wave of feminism saw controversy and disagreement between feminist as it argued many new issues. Altogether it gave rise to powerful women. 
Fourth wave feminism began in the year 2012 that mainly focused on women empowerment. As the first three waves of feminism gained liberation, individualism, the fourth wave looks keen on reasoning out the marginalization and oppression of women in society. It mainly argues on issues like equal pay for work, equal opportunities, overcoming gender norms, etc. It uses all media platforms to mobilize and raise voice against abusers of powers and demands justice for women's physical tortures.

Since feminism has handled many tough times in the past, it is now in a position to anticipate any challenge on its way. It is the high time that the deadly pandemic is hitting the world with its violent terror creating new challenges upon women. Feminism as an empowering agent has the framework of surpassing the tricky situations.

Pandemic is not something new in the history of human evolution. Some hundred years back, between 1918 and 1920, the world has faced a similar pandemic situation. It was the Spanish Flu. For which, 500 million people were affected and 50 million have died. It was very deadly comparing to today's context of high medical development. Before this pandemic, many countries had faced Cholera Pandemics between 1817 and 1860, where the virus spread through trade routes and by soldiers. Understanding the situation the then British government even has announced quarantine orders for the Ships in British ports. But that couldn't resist the virus' attack. Thousands and millions of people died all over the world.

A study says that the Cholera pandemic of the 19th century is very similar to covid19 because the same as COVID 19; it started in Asia and spread all over the world. Loss of human life and trade loss has been the major effect of the pandemic. No proper practice of social distancing had been seen as the major reason for the widespread. But, these days, due to science and development, people are now capable of bearing the attack of the virus with the proper spread of awareness. December 19, the first mild symptoms got displayed in a hospital at Wuhan in China. From then it started its deadly attack on the human race. As a result, the World Health Organization announced a Public Health Emergency of International Concern on 30 January 2020 and pandemic on 11th March 2020. Because of the severity of the pandemic, global society and economics see a major disruption that leads to the global recession, global famines, and shops, universities, colleges, and schools were closed. Events related to sports, religion, politics have been stopped. It also escalated the spread of rumors through social media. Reading that, people started discriminating against the people who have been affected by the virus. Mainly Chinese were seen in such away. Even in India, some sections have been discriminated against by the name of the virus. The only good thing happed is the reduction of pollution and a decrease in the emission of greenhouse gases.

Though men and women are equally prone to this disease, women suffer a lot than men. Apart from the infection of the disease, both men and women have lost their jobs and have faced a large economic crisis, starvation, and many. Women losing jobs is higher than males in the US. Especially women are likely to end up a backward growth. Feminists are worrying that Pandemic should not be a push back for the women. The situation made family life difficult by working at home, taking care of the online schooling for the children, and caring for other members of the family. Thus women's suffering is immense. Justin Roberts, the founder of Mumsnet says, "It's no secret that mothers still carry most of the burden of childcare and domestic work in most families". These instances show the reality that women would be the major victims always and even during the pandemic. 
Women experience more psychological pressure than men. Research by the Hotchkiss Brain Institute at the University of Calgary, Canada states that women feel stressed than men in tough times. For which they have used animals and compared their responses with human beings. The study talks about the importance of social interaction and also foregrounds the consequences of social and environmental changes impacting the human psyche. While comparing this conception, today's pandemic has made various changes in society like isolation, working from home, poor social interaction and this will impact humans especially women.

Women experience rejection in working places and families. It is argued and most debated everywhere that at the institutional level, the top most positions have been retained largely by men. The same is within the family level also. They are being rejected in higher responsibilities affect women psychologically also. This type of rejection has increased during the pandemic by pointing them as weaker sections and delimiting their roles in institutions and houses.

Since the consequences of pandemic fall on the entire human community irrespective of gender, some data reveal that the indirect effects of it fall more on women. Both working women and Non-working women are suffering pandemic to a large degree. Psychological and physical tortures by the patriarchy during the pandemic disturb their ordinary course of life. Working-class women suffer work from home or find it difficult to travel to their working place. In some families, both husband and wife lose their jobs and some families struggling with a single income. In all these conditions, women had to take care of everything like children, household works, and her. Perlin Aslantas, the only female bus driver in Edirne, Turkey says "When I arrive home, I wash my hands, and head straight to the kitchen" "I feel like I'm resting more on the bus while driving". This is just one example that reveals the reality of women in every house. She also says that her men colleagues will rest after the work but she couldn't take rest because she is a woman. The same is the case with women who work at IT companies and other big working environments. Especially, the work from home concept gives more stress for them that they have to settle down the homemade tensions and everything. Thus the pandemic is excerting a huge pressure on women and they have to overcome it.

The aftermath of the corona attack would be unpredictable. The already existing system of practice in all the domains will see a changeover. These days, the workplace is becoming an outdated concept. A complete virtual based system is going to be evolved. The new normal has to be accustomed to both men and women. Women with empowerment can outsmart men. Their progression towards achievement has to be shouldered by feminism. In these scientific advanced days, already women have greatly achieved in various fields. Their imprints have been found in many areas including space research, educationist, and business. The stereotypes of women are already broken. Hence Feminism has to empower them morally and psychologically.

Simone Ramos to the BBC says that women have to work harder after the pandemic. In her statement "Very early in my career I realized I needed to leave the office later, I needed to prove myself three times more than any man"; She is an adviser for the Brazilian Association of Women, wanting all women to have a clear focus, determination and goal in bringing themselves higher than men. This kind of positive note from achieved women induces a productive mindset in women. 
Feminist ideologies and thoughts were the strong hope of women in today's generation. These thoughts and ideas are hidden in literature and would boost up the famishing minds.

Literature has depicted many empowered women characters in many places. Reading of these characters would be a strong motivation to them during tough times. Many female characters in literature have faced challenges and have overcome that tremendously. For example, Beatrice, in Shakespeare's Much Ado About Nothing, Artemis in Homeric Hymns, Alice in Lewis Carroll's Alice in Wonderland, etc. All these characters are exceptionally strong and zealous in facing struggles.

Though, Jane Austen a famous writer some 200 years ago, her works still impact women of today. Some modern feminists may not agree with her feminist ideologies because she followed a conventional life that she expected women to marry and suggested men and women to be treated equals. Her statement on feminism clarifies it. "The doctrine, advocating social, political, and all other rights of women equal to those of men". In her creating of strong female lead characters, she suggests today's women adopt their leadership qualities in them. The character Elizabeth Bennet, the protagonist of "Pride and Prejudice" was a strong, honest, and loving person who tends to take quick judgment marks the success of the story. "My courage always rises at every attempt to intimidate me". In another novel "Emma", the protagonist Emma has been described as a clever twenty year old matured girl who takes care of her father. This motherless girl exhibit confidence and ability in decision making that reveals her leadership skill.

Hua Mulan, a revolutionary women character present in a Chinese folklore song Ballad of Mulan. Mulan is fearless that she disguises her father and joins the army. Though his father is too old and the brother is too young she takes up the role. She battles twelve years and has achieved many victories for the country. Many modern women are Mulans that they are taking up responsibilities in shouldering their family and society.

Hester Prynne a most notable character in literary history has fought against oppression. Charlotte Bronte the famous writer has introduced the character Jane Eyre who has been punished despite being honest and loyal. However, she overcomes hard times in her life and came as a transformer. "I am no bird; and no net ensnares me; I am a free human being with an independent will."

Thus literature depicts characters that transformed. Those characters can make the present day women realize, coping up, learning from difficulties, and taking up responsibilities. Though these characters faced struggles in the society and family, they exhibit potentials and possibilities. By ruminating these characters, women can gain confidence in facing today's challenges.

\section{References}

1. Ghorfati and Medini, 2015, "Feminism and its Impact on woman in the Modern Society"

2. Rana Neeraj, 2018 "Feminism in Literature","International Journal of Advanced Educational Research"

3. Barry Peter, "Beginning theory: An Introduction to Literary and Cultural Theory" 1995,2002 


\section{Websites}

1. https://www.globalcitizen.org/en/content/was-jane-austen-a-feminist/

2. https://www.redbubble.com/life/female-literary-characters/

3. https://www.britannica.com/topic/feminism/The-suffrage-movement

4. https://shodhganga.inflibnet.ac.in/bitstream/10603/38612/5/06_chapter2.pdf

5. http://dspace.univ-tlemcen.dz/bitstream/112/7902/1/amina-ghorfati.pdf

6. https://www.sciencedaily.com/releases/2016/10/161011125959.htm

7. https://www.weforum.org/agenda/2016/05/five-stories-that-show-women-fightingsexism-around-the-world/

8. https://www.nature.com/articles/palcomms20179

9. https://www.researchgate.net/publication/337705338_UNDERSTANDING_FEMINISM

10. http://www.dvac.org.au/wp-content/uploads/2015/06/What-is-Feminism.pdf

11. https://www.bu.edu/arion/files/2010/03/Feminism-Paglia1.pdf

12. https://www.researchgate.net/publication/337705338_UNDERSTANDING_FEMINISM 


\title{
WOMEN'S CARING RESPONSIBILITIES IN COVID-19

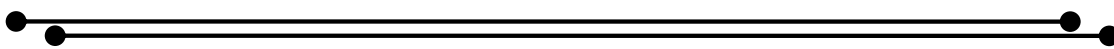

\author{
Dr. S. Chitra Devi M.Com, M.Phil \\ Assistant Professor, Department of Commerce, \\ Nagarathinam Angalammal Arts \& Science College, Madurai
}

\begin{abstract}
The objective of the paper is to tracing the conceptualization of women's caring responsibilities inside and outside the home during COVID-19. It is mainly concentrated on the consequences faced by women during the pandemic situations. All over the world, from wellbeing to the wealth, safety to social protection, the effects of COVID-19 are exacerbated for women. As COVID-19 spreads around the world, the impact of the pandemic on women is becoming increasingly severe.
\end{abstract}

Keywords: pandemic, economy, health, responsibilities

\section{Introduction}

"A woman is the full circle. Within her is the power to create, nurture, and transform."

\section{- Diane Mariechild}

Now a days, the respect of the feminism is celebrating only twice in a year on the occasion of women's day and Mother's day. Feminism is revealed not only in the form of written or by oration but also expressed in our activities. Yet women should be respected, valued, understood and adored in every moment of our life. The COVID-19 pandemic is creating a profound shock worldwide, with different implications for men and women.

Women are facing quite numerous difficulties physically and mentally to overcome the pandemic situation. Women are serving on the frontlines against COVID-19, and the impact of the crisis on women is stark. The pandemic quarantine and crisis enlarges the load of women especially in house hold works like taking care of their children's education, managing the finance budget of the home, supervising the health system of the entire family, looking after their chores, tend to be a good employee, etc. Due to the stressful condition, most of the women are overcoming the level of mental and physical stress. Women are among those most heavily affected.

In the health care sector, almost $70 \%$ of the space is occupied only by women. So women are at the front position of the scuffle against the pandemic condition as they make up health care workforce, illuminating them to superior hazard of infection, although they are underestimated in direction and decision making processes in the health care sector. In addition, due to constant gender inequalities diagonally many proportions, women's professions, occupations, earnings and wider livelihood may be more uncovered than men's to the projected common economic fallout from the crisis. Among seniors, worldwide, there are more aged women living unaided on low incomes - putting them at elevated risk of economic uncertainty.

Across the world, there is a chance of rising women's workload as more people are homebound for a sustained period of time and responsibilities related to care giving works have increased during the lockdowns and self-quarantine period. According to the report of the 
Economic Cooperation and Development (OECD) Organization, every day Indian women are spending nearly six hours for their unpaid care work. On the other hand, Indian men use not as much of than an hour on an average doing the similar. As per the survey in Worldwide, women perform $76.2 \%$ of total hours of unpaid care work.

COVID-19 is expected to have major consequences on family work due to increased housework and childcare resulting from the closing of schools and nurseries. Many women are already struggling to get to work at all, given the need for at least one parent to stay home with the children. There has been a shift towards a more equal distribution of household and childcare between men and women, but most of the extra work caused by the crisis has fallen to women.

\section{Women's caring responsibilities at home}

Women are habitually the main caretakers in their homes, communities, and health facilities, which puts them at an increased risk of contracting COVID-19. Women are not only influencing employment in the health care sector, they also afford a large amount unpaid work at home. Women's unpaid workloads are rapidly increasing at the time of COVID-19. Due to COVID-19, all the schools and child care centers in the nation have been closed. As a Parent, women have major responsibilities in educating their children at home. Most of the time is passed by spending on child care and supervising their learning. To a great extent of this extra trouble is likely to fall on women. In the same way, any increases in time spent in the home due to internment are likely to guide to increased routine housework, including food preparation and cleaning. Satisfying these demands will be hard for many parents, especially for those that are necessary to carry on working.

On the optimistic part, one possible upshot of pervasive school/facility closure and the shift to home-working is that lots of men will be uncovered to the twice saddle of paid and unpaid work frequently faced by women. It is very hard for the working women to manage the timing for doing the house hold work and their office work during the quarantine period. So it will mechanically boost their level of stress and it makes them ambiguity moreover affects their family life. Leisure has great significance in women's life. One should not ideal away one's leisure. But most of the women in the family do not have proper leisure time. Only when the use the leisure time properly, it brings relief to their mind and strength to their body.

Women are diverse from men - It is merely building a case for recognizing the many variations between the genders. For instance, believe the disparity in nutritional supplies. Comparing to our predecessors, $21^{\text {st }}$ century women require additional nutrition like iron during the time of pregnancy and also in feeding the baby. They also need more protein, strength and energy after the age of thirty.

Unfortunately, in India, women are suffering from poorer nutrition than men. Health is a state of complete physical and mental well-being. This means that both the mind and the body must be completely fit for women to be considered healthy. Proper diet, rest, exercise (walking, running, and playing), and correct posture are essential for women to stay healthy. But there is a habit being followed by most of the houses in India, women are supposed to eat last after feeding the entire family, and they are in the position to eat the leftover food. We all know that our diet must include adequate amount of different components of food for our body to be healthy. As they do not get a proper diet, they are often falling sick. 
Let's seem at the serious role that women can play in the welfare of the family. A patient of mine, a woman who came in with fatness and diabetes, made it a point to pound good eating habits in her children because she knew of the wellbeing threat that they had inherited from her. She altered not only her own eating practice, but also those of her family and even those of her neighbours!

This is not to say that women must not engage in care taking work. In fact many women cherish and prefer care taking activities when it comes to children and other close dependents.

However, the fact is that a woman asking openly for rest or support with domestic chores, is viewed with disapproval at best, and faces emotional / physical abuse at worst. This becomes particularly distressing during certain phases of women's lives like pre menopause / menopause, pregnancy or soon after childbirth, uncomfortable menstruation and more. Already vulnerable due to huge physical transitions, unexpected health issues and discomfort, a lack of domestic and emotional support can have long term consequences on their mental health.

In countless ways, women play an important role in shaping the health and well-being of a nation. Not only should this contribution be recognized for what it is worth, but we should also do our part to enable them in every way that we can.

\section{Responsibilities of Women's Leadership in COVID-19}

Since the starting time of COVID-19 pandemic, most of the media's focus has been paid to the involvement of women leaders and the effectiveness of their handling of corona virus pandemic. The activities of women leaders in New Zealand, Taiwan, Denmark, Island, Germany, Norway, and Finland are mentioned as supporting evidence that women manage this crisis better than men. Pragmatism, trust in collective common sense benevolence mutual aid resilience and humanity are mentioned as general significance of the women to succeed. Female leaders took the pandemic critically and did not under evaluate the hazards.

The report of the latest surveys shows that Ms. Jacinda Ardern, Prime Minister of New Zealand has topped score of $60 \%$ for her leadership performance in the activities like the White Island volcanic eruption, the Christchurch mosque attacks and the pandemic. She has been appreciated for her leadership fashion during the COVID-19 crisis. During the period of pandemic, her efforts have been largely succeeded in meeting its ambitious goal of eradicating other than just controlling.

Angela Merkel, Prime Minister of Germany also well known as a scientist, decreased the spread of virus in the country is the ability to lead through major crisis indeed her greatest strength. Angela Markel's government in Germany unprejudiced a lot of information epidemiological models in shaping how to struggle with corona virus. She is a political leader who executed, distinguished, and embodied evidence based thinking when it mattered most.

Tsai Ing-wen, the women president of Taiwan, has presided over one of the most flourishing hard work in the world at containing the virus, using testing, and contract tracing and isolation process to manage infections without a full national lockdown.

Sanna Marin, who is 34 years old and considered to be the youngest among the women prime ministers in the world and came into charge just few months before the virus emerged in China. She made her people to follow the strict lockdown and Finland has managed to contain the outbreak with lower cases. 
Katrin Jakobsdottir's quick response to the pandemic has made Iceland to record lowest death rate in Europe, though the country has recorded more positive cases. This antagonistic testing and tracing practices made the country to avoid strict lockdowns and opened for the tourism.

\section{Overhauling value systems at the workplace}

Most of the women are performing their profession/office work from their home due to the situation of lockdown in COVID-19. As per the result of various studies, women are earning lower income than men. So they are likely to be more stressed and depressed. It obviously creates anxiety and more tension to women that they are not equally treated in the society According to a survey by the Kaiser Family Foundation a much larger amount of women be troubled regarding loss of income due to distraction of work caused by Covid-19 as compared to men. Under "usual" conditions women previously face a major wage gap.

Now a days, some of the working women are in leadership positions are more likely to experience from "misery, social tension and loneliness" due to pessimistic perceptions around women in power. This is noteworthy again because public in leadership positions have better income control and improved socio-economic grade. However in case of women, these factors are more likely to make them further stressed.

Women inflowing the workplace all together are a relatively recent occurrence and cultural attitudes are so far to square with this shift. For a number of women, workplaces can be a immense positive fortification for their intelligence, self-governing identity, and economic self-sufficiency; at rest there remain some inevitable obstacles to victory along with composite balancing acts. It should be a subject of a few group mortification that "mom guilt" is such a invasive experience- this is the guiltiness that mothers suffer for being insufficient or having to split their time between child-rearing and further commitments.

As per the view of sociologist Tetyana Pudrovska, "Leadership is acknowledged as normative and legitimate in case of men, whereas women face other stressors overcoming depressing stereotypes and other resistance, most probably even stress from home". Covid-19 has taught us that work from home, flexi work and other models of engagement with the workplace are not only possible but can also be productive. It is significant to take apart the default of men workers at the workplace and integrate policies and behaviors which are wideranging, compassionate and cooperative of equal lifestyles for all sexes. It will create the good and equal lifestyle culture in the workplace.

\section{Conclusion}

On the basis of demographic factor of our nation, part of a population of the country contains women, and they ought to have same significance and rights in the family, community and, all around the society. For the well developed nation, women also treated equally like men in all spheres of nation. The strength and ability of the women are under calculated based on their gender, and they should be given equivalent chance to exhibit their capabilities and talents. It is vital for us to recognize the significance of women in our society. 


\title{
SAFETY, SECURITY AND WELL-BEING OF WOMEN IN TERMS OF COVID - 19
}

\author{
Dr. R. Muthulakshmi \\ Guest Lecturer, Department of Education, \\ Lady Willingdon Institute of Advanced Study in Education, Chennai
}

\begin{abstract}
The word women reflect many messages by their own actions which appreciates reactions from others. The successful effort behind every woman is converted in to systematic reform and continuous improvements for national development. The emergence of digital world draws the linkages between social relationships, political economy, safety and awareness, physical, mental well-being and occupational wellbeing of women at diverse domains. In general it is difficult for women to maintain healthy and harmonious life styles during the pandemic period wherein they have to give substantial attention to their family and occupation. Covid-19 clearly shows that safety, security, mental and physical well being of a woman needs to be addressed so that their health infrastructure will be enhanced to achieve women empowerment. Henceforth the role of women in rural and urban areas has to be identified and proper guidance should be given to them about how to be attentive on their own safety, security and well-being. Therefore the objective of this paper is to create awareness about safety, security and well-being among women at various levels.
\end{abstract}

Keywords: Health, Safety, Security, Well-being, Women, Covid-19 and Pandemic period.

\section{Introduction}

Since the ancient period, India has been known for its culture, tradition, belief and values which are highly influenced grow and development of our nation. The place of women is critically discussed in each period and it shows that women are the backbone of society and their role is significant for the systematic way of living and initiative. From the discussion, the following question raised.

- Is the safety and security of women ensured?

- Is the well-being of women addressed?

To find the answers, women need to be progressed and their issues should be addressed as well as women must understand their strengths and aware about their health to grow and flourish in life. Women empowerment is a word conveys more meaning for their exploration. The real meaning of the women empowerment is to make them well educated and leave them free so that they can become capable and mentally strong to take their own decisions in any field. In the international context, Sarojini Naidu, Indira Gandhi, Michelle Obama, Hillary Clinton, Angela Merkel and many more women are identified themselves as very strong, talent and independent women. The empowerment of women would mean encouraging women to be self-reliant, healthy and independent, have positive self-esteem, generate confidence to face any difficult situation and invite active participation in various socio-political forums. In order to enhance the role of women in every field, their safety, security and well-being should be monitored in all the situations. 


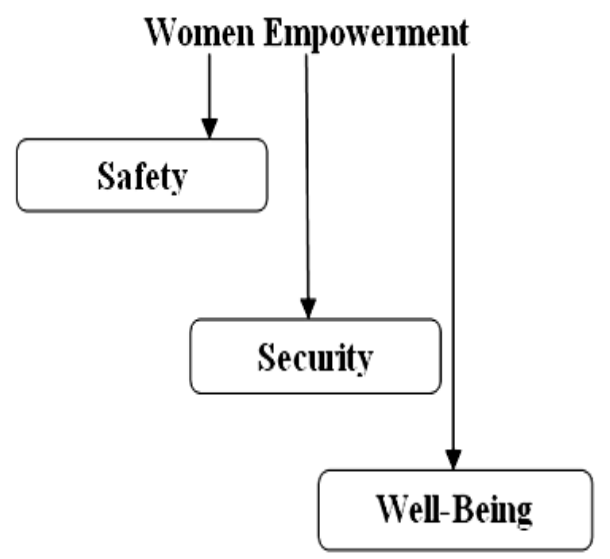

\section{Covid-19}

Coronavirus is a type of virus creates infectious disease among living creatures that causes throat pain, tiredness, cough and cold, breathing problem and fever. According to World Health Organization (WHO) COVID-19 is the infectious disease caused by the most recently discovered corona virus. This new virus and disease were unknown before the outbreak began in Wuhan, China, in December 2019. COVID-19 is now a pandemic affecting many countries globally. The disease spreads primarily from person to person through small droplets from the nose or mouth, which are expelled when a person with COVID-19 coughs, sneezes, or speaks. These droplets are relatively heavy, do not travel far and quickly sink to the ground. People can catch COVID-19 if they breathe in these droplets from a person infected with the virus. This is why it is important to stay at least one meter away from others.

Covid-19 is a pandemic period by which safety, security and well-being of every woman are vital to reduce their various health issues and psychological problems.

\section{Safety}

Safety is a state of being protected from potential harm or something that has been designed to protect and prevent harm. Safety is vital for many reasons which includes,

- Reduce absenteeism

- Reduce health issues

- Create satisfying environment

- Create awareness

\section{Security}

Security refers to all the measures that are taken to protect everything and ensure that only people with permission enter everywhere or leave. The importance of security is as follows,

- Protection

- Prevention

- Execution

- Adaptation 


\section{Well-being}

Well- being is the state of ways and means of maintaining proper mental, physical and social phases. Well-being integrates and promotes all these three features resulting in more holistic approaches to disease prevention and health promotion. Well-being is significant because

- It correlates well-being with other states such as social connectedness, economical Productivity and health behaviors.

- It helps to enhance environmental awareness.

- It enhances engagement and active performance.

- It appreciates happiness and satisfaction in life

- It promotes positive values and reduces undesirable behaviors.

\section{Creating Positive atmosphere for Women in Covid-19}

Around the globe, countries are struggling to lead in the spread of the novel corona virus outbreak. In India, nearly 1.3 billion people are currently under a nationwide lockdown, which has been extended till date. Detrimental climate against women tends to increase during these epidemics and pandemics. Older women, pregnant women and women with disabilities are likely to have additional risks and needs. Women who are displaced, migrants, and living in conflict-affected areas are particularly vulnerable during pandemics. Insecurity in various aspects including that is

- Fear

- inadequate accessibility of livelihood things

- health issues

- unemployment

Increases their stress level and mental illness. The UN has been alerting the world about this women's problem and seeking attention to the need and progress to promote strategies in protecting women against insecurity problems. The article in the Hindu news paper (April 13, 2020) revealed that it is vital for policymakers to address the needs of these women who are playing an indispensable role on the front line in the war against COVID-19 - as health workers, sanitation staff, caregivers, scientists, and as long-suffering housewives. Priority measures to help domestic violence victims, without detracting from the overall anti-COVID19 strategy of lockdown, should be initiated by the government, and steps to protect victims of domestic violence be made a part of overall anti-COVID-19 action plans. From the discussion the three features namely

- Safety of Women in terms of Covid-19

- Security of Women in terms of Covid-19

- Well-being of Women in terms of covid-19 should be addressed.

\section{Safety of Women in terms of Covid-19}

Government of India has been initiated many constitutional regulation to ensure the safety of women at various places. In collaboration with UN Women association, Indian Women empowerment committee plans to develop a human rights-based intervention program that aims to make certain that women and girls are socially, economically and politically 
empowered, which includes freeing them from violence. Further the safety of women is significant during this covid-19 period. According to WHO, during covid-19 pregnant women should follows,

- Stay at home as much as possible and keep the number of visitors at home including maids to a minimum.

- Keep social distancing from any other person in the house.

- Wash hands frequently with soap and water for at least 20 seconds or use a disinfectant.

- Cover mouth and nose with bent elbow or tissue during coughing or sneezing and dispose the tissue in the bin.

- Avoid touching eyes, mouth and nose as much as possible.

- Consumes balanced diet

Further, Ministry of Human Resource and Development of India instructs various educational institutions to conduct awareness generation programs and publicity campaigns on various laws relating to women and their rights through workshops, panel discussions, conferences, seminars and training programs, advertisements in print and electronic media. Women Safety Division is also initiated in order to coordinate various initiatives for women safety measures.

\section{Security of Women in terms of Covid-19}

There are few laws are constituted in India to concentrate on the security measures of women and girls. The Ministry of Women and Child Development has been administering various special laws relating to women such as the Protection of Women from Domestic Violence Act, 2005; Dowry Prohibition Act, 1961; Indecent Representation of Women (Prohibition) Act, 1986; and the Prohibition of Child Marriage Act, 2006. In addition to that the Juvenile Justice (care and protection of children) Act, 2015, the Commissions for Protection of Child Rights Act, 2005 are also administered. In covid-19 period, the violence against the women is increased due to insecurity illness. To avoid these risk factors women need to secure themselves with following measures along with above defined laws,

- Aware about the present situations

- Be confidence

- Regular reading

- Make sure to know about Government initiatives related to women

- Be a strong and courage

- Fluency in Communication

In addition from the Fifth Five Year Plan (1974-78) onwards has been a marked shift in the approach to women's issues from welfare to development. The empowerment of women has been recognized as the central issue in determining the status of women in the modern years. The National Commission for Women was set up by an Act of Parliament in 1990 to safeguard the rights and legal entitlements of women. The 73rd and 74th Amendments (1993) to the Constitution of India have provided for reservation of seats in the local bodies of Panchayats and Municipalities for women, laying a strong foundation for their participation in decision making at the local levels. 


\section{Well-being of Women in terms of Covid-19}

Health is the basis of all our activities. Poverty is an important barrier to have positive health outcomes for both men and women which tends to yield a higher burden on women and girls' health due to various factors such as malnutrition, unhygienic sanitation and use of unsafe cooking fuels. If human body is not healthy, they will suffer from various types of complexes and conflicts. Women and girls, who already faced health and safety implications in managing their health and hygienic process wherein well-being in its known for physical and mental well-being which stimulates positive behavioral approach. Having mental hygiene is vital to solve problem and step forward in life. Mental hygiene is a science which helps an individual to understand the ways which they should follow for leading a peaceful and happy life.

L.F. Shaffer defined that mental hygiene helps to develop a well- balanced personality. Hence to become a well-being mental hygiene and positive mental health is important that initiates desirable behaviors among human beings. Gender-responsive policies and practices related to education, women's economic empowerment, food security, livelihoods, nutrition, healthcare, and other key topics are indispensable in the framework of the pandemic.

According to WHO and UNICEF for physical well-being hand hygiene and sanitation is a critical element in preventing the spread of COVID-19. Yet, 3 billion people, or 40 per cent of the world's population, do not have a hand washing facility with water and soap at home. In order to avoid that the following measures should be taken

- Improving financing to address women's health priorities and integrating gender budgeting across health policies and programs.

- Assessing the impact on women's health of national strategies and action plans within and outside the health sector to identify critical actions

- Including gender perspectives in initiatives addressing the social, economic, environmental and cultural determinants of health and health equity

- Strengthening opportunities and building capacities for women's participation as citizens, careers, users and patients in leading and managing health policy and health system actions.

Further women have to understand some common well-being measures which includes proper communication, balance between work and family, doing regular exercise, practice mindfulness, knowing fundamental rights and updating on various initiatives of Government in women empowerment.

\section{Conclusion}

The role of women is commendable in society for its steady development. During this pandemic the right lessons from the COVID-19 crisis, which demands that we take a hard look at how we value and pay for women's contributions to health care, social services, and the economy. In India there are many women reformers and writers who work for uplift and betterment of the female counterparts. Women education at all levels need to be improved and women come forward to become skilled at higher education. The Government has set up Nirbhaya Fund for projects for safety and security of women, for which Ministry of Women and Child Development is the nodal authority for appraising/ recommending the proposals / 
schemes to be funded under Nirbhaya Fund. Hence it can be concluded that equal access to women at all the fields, quality education at all levels, career and vocational guidance, employment, equal remuneration, occupational, safety, social security and health aspects has to be enhanced for the women welfare and empowerment.

\section{References}

1. Ahmad, R.K. "Role of Education in the Empowerment of Women in India", Journal of Education and Practices, vol.6, no.10, 2015, pp-17-26.

2. Chaube, S.P. Educational Psychology, $3^{\text {rd }}$ ed, Lakshmi Narain Agarwal, 1997.

3. Jayanthi Natarajan. Women's safety during lockdown. The Hindu, Daily Newspaper, 13 April 2020.

\section{Web References}

1. https://www.thehindu.com/opinion/op-ed/womens-safety-duringlockdown/article31324318.ece

2. https://www.who.int/topics/womens_health/en/

3. https://impakter.com/covid19-women-peace-security-risk/

4. https://www.euro.who.int/_data/assets/pdf_file/0020/314534/66wd14e_WomensH ealthStrategy_160519.pdf

5. https://www.un.org/en/healthy-workforce/

6. https://www.sentinelassam.com/north-east-india-news/assam-news/status-ofwomen-in-indian-society/ 


\title{
NEED OF TECHNO-LITERACY AMONG WOMEN DURING PANDEMIC COVID-19
}

\author{
Dr. R. Sengamalam @ Vaanathi \\ Assistant Professor, Department of Education \\ Madurai Kamaraj University, Madurai
}

\begin{abstract}
It is known that women are the half the sample of whole population, they should have appropriate techno-literacy to meet their requirements, to fulfil their wishes, to make their role alive, to move their next level personally and professionally. If women are provided with appropriate digital tools, it infers a concrete opportunity for women to tackle longstanding challenges of gender inequalities, including access to employment, income, education and health services. Techno-literacy is also the right to women in this digital scenario especially in this pandemic period. In this digital era in general and this pandemic COVID19 in particular, the techno-literacy is one of compulsive need of the girl or women to fulfill their requirements personally in general academically in specific. This chapter outlines such need of technoliteracy among the women in this pandemic period especially.
\end{abstract}

\section{Introduction}

Nelson Mandela in the year 1995 said that 'In the $21^{\text {st }}$ century, the capacity to communicate will almost certainly be a key human right. Eliminating the distinction between the information-rich and information-poor is also critical to eliminating economic and other inequalities. ..... and to improve the life of all humanity'. To be frank, we as a whole are not there yet, and it too often women who are short-changed when it comes to access to communication, information and technology in very specific. The Alliance for Women in Media Foundation (AWMF) issued the special report to shine a light on digital literacy with a particular focus on media. This distinct report addressed the gender-based knowledge divide with a specific focus on girls, women and workforce training. In its absolute terms, women are accessing and using lesser in information and communication technologies than their counterparts. As a conclusion, women have less interest in using and accessing technology less capable using technology. Contrary to those kinds of claims, a careful and broad-based statistics tests in 25 different countries have revealed that the women access and use media is a direct result of their unfavourable conditions with respect to their employability, educational opportunities and their financial income and independency. Therefore, women have and use fewer digital media not because they are women as such, but because social practices provide them with less employability, educational opportunity and less income means financial independency, which leads to less digital media access and usage. It also suggested that controlling such above hindering variables, women turn out to be more active users of digital tools than men. Also, it is traditionally thought of a being better communicator than men, it seems to have a natural proximity with these new tools for communication. 


\section{Common Reasons for not availing educational and other opportunities among Women}

- Poverty: The education is a glorious area that is significant for the development of the individual, society and nation. Children who are in poverty condition - concerned with the low income of the individual, often encounter various obstacles within the course of acquisition of education and development of literacy skills. On other hand, poverty is a multi-dimensional problem that includes low access to opportunities for developing human capital and to education. Since, girls are secondary choice to have education from her family and they may not be permitted to get education easily because of poverty. Secondary and higher-level achievement of girl children and betterment in family economic condition significantly are related very much. It is well-known fact that the enhancement of domestic economic condition could be improved if the girl children are being given a very great educational opportunity.

- Cultural Norms and Practices:Cultural practices are highly influenced in modifying and developing an individual behaviour including the use of violence. Here, norms can protect against violence, but they can also support and cheer-up the use of it. Usually cultural practices reflect values and beliefs held by members of their society and nation. Some of those cultural practices are beneficial to all the members while some of them are really harmful to specific group - women in the society, and some of the practices like female infanticide, early marriage, more compulsive childbirth, dowry price, hesitation in property rights. Hence, girl children and women are continuing to be denied and violated. Hence, it was not easy job to get education equally in prior.

- Violence: violence against women and girls is the most common form of abuse worldwide; it is found that through this affecting one third of all women in their lifetime. This Violence Against Women and Girls (VAWG) limits progress towards the Millennium Development goals, violates women and girls' rights and can have a negative impact of long-term peace and stability. Some of them are: ChildMaltreatment, Intimate Partner violence, self-harm, sexual violence, youth violence and community violence. These types of violence are very much affected the girls and women psychologically and emotionally, which are the important primary factors which help to move and get their educational opportunities.

- Girl Child Marriage: In India, girl child marriage remains common in spite of implementation of many policies and programmes to eliminate such practices. As per the data of National Family Health Survey (215-16) using linear regression models revealed that girls with no schooling and primary level of education are having higher probability of getting married at an early age, hence likelihood of girl child marriage start declining with secondary level of education significantly reduced the probability of girl child marriage. Other factors - urbanization, religion, women autonomy and region also significantly influencing in the occurrence of girl child marriage.

- Physical Reasons: It is known fact that girls are expected to participate in the domestic life of the household long before their brothers irrespective of their status with her, and they are practiced to all the works in their home and simultaneous they may not be permitted to have more food than their co-brothers in prior in great extent and this practices are being reduced now-a-days to some extent. One of the studies 
done by Anthropologist, Margaret Egnor revealed that for South Indian at lease, the most profound bond of all is that between mother and daughter, a 'bond which is felt to be part of all growth, of all continuance and creation. There is a contradiction at the heart of the attitude towards daughters in India; the bringing to birth of one like oneself, who is turn will bear another, is an image engraved everywhere in Tamil culture'. It is believed that women are weaker than men and are having physical discomforts like during mensuration, they may be permitted to think, react, do and make certain things still. These are all happening because of unaware such physiological nature among the people usually.

\section{Unaware of their Strength of a Woman}

The strength of a woman is not only measured by her decision taken and also when she took and at what context she made such decision; a woman always considering all the factors and dimensions of a problem in all directions before arriving into any conclusion and to give solution for such problem she faced or given. In this regard, some of the evidences are:

Scientifically, 'women tend to live long than men due to a complex interaction of biological, environmental and social factors' as per the study published in the Journal of National Academy of the United States of America; also it highlights the fact that women are more likely to survive tougher conditions - famines, extreme climatic changes, and disease epidemics, as compared to men and have a stronger immunity too. As per the study conducted at McGill University, women have a higher threshold for pain than men. A study published in the journal Emotion found that women are better at identifying their negative emotions. As per the study output conducted at the Binghamton University in New York and University College London, in the case of a break-up, women may feel the hurt deeper than men, however women tend to heal faster while men simply move on and never really restore. As per the study conducted by the researchers from the Ben Gurion University of the Negev, the University of St. Gallen and NYU Shanghai, women tend to cope with pressure than men and this ability of women is due to the fact that cortisol, the stress hormone, tends to increase more rapidly in men than in women. It is proved that the volume of brain in men is more than women, but women still trying to beat them when it comes to those I.Q. tests. There is solid scientific reason for it cited by a study done at the University of Edinburgh, and it recorded the truth that women have thicker cortices, which are the area closely linked to improve the performance of intelligence tests. In fact, the cognitive skills of women are sharper as well. In the same way, another study - study conducted at the Washington University School of Medicine, revealed that women can maintain their cognitive skills and have better memory than men; as men's brains tend to diminished faster with age as compared to that of women. By the British research, it is cleared that women are better at reporting and explaining their symptoms to a doctor and seeking timely medical helps in case of a health issue in comparison to men. Another one study published in the journal of The Royal Society Publishing revealed that women's leg may be stronger than that of men; of course, a unit of a fit woman's muscles can produce the same force as that of a similarly fit man - women just have a lower muscle mass, not muscle strength. 


\section{Need of Technology Today}

Techno-Literacy is the capacity of any individual, make her/him work independently and with other through appropriate use of medium and technology tools in managing integrating, evaluating, creating and communicating information in a right way with full of productive output. Also, it enables people to perform their daily activities and to support their capacity to make informed, responsible decisions that affect them as individual, society as a whole and their environment.

It is well known fact that technology has transformed our daily life not only individually it made the world globally; it has developed remarkable tools and resources not only entertainment purpose and also in all dimensions of our lives and make them our fingertips. Today technology has tailored the way for multifunctional devises - smart-watches, smart phones, smart television and even smart home appliances. Computers are very important in all fields and they are become more faster operation, higher speed access of internet and very light in weight with portable size too than before. Of course, technology and its day-to-day updating devices and configurations, our lives changed easier, faster, comfortable and with more fun without any doubt. But my view is to focus a woman feels really more comfortable in general life and in academic activities in specific. On behalf of technology, now-a-days women are more comfortable physically in some extent along with hinderances, but it is required to have better techno-literacy in the use of social media and other electronic transaction to some extent safely and productively by considering its negative side too to meet their real purpose effectively.

\section{Level of Availing Technology among women in India}

By 2011 census of India, an effective literacy rate for men was 82.14\% while for women was 65.46\%. But, in accordance with UNICEF's, "the State of the world children 2017 Children in a Digital World report only 29\% of all internet users in India are females. In the same, IAMAI-Kantar IMRB joint survey conducted in 2017; they reported, "Internet in India 2017" as an estimated 143 million female internet users in India. World Bank Report in the year 2017, 'India has among the lowest female Labour Force Participation Rates (LFPRs) in the world'. NASSCOM in partnership with the Open University, UK at its $10^{\text {th }}$ edition of NASSCOM Diversity and Inclusion Summit, 2017, 'the Indian IT sector is to be heading in the right direction towards recruiting and retaining more women.' The above studies and surveys were done in 2017, but the current situation is different due to critical situations they faced and external forces they experienced. Even though, the women belonging to urban background are being given more opportunities and availabilities, the rural women may not fully available with such exposure or simply they are not that much realized the need of techno-literacy at least. But the explosion in technological advancement made a great revolution in recent years to a great extent both rural and urban and make them connected through the spectrum technology hence, all are using mobile phones now-a-days whether they are ordinary call making and text message sending or high-end smart phones. 


\section{Impact of COVID-19 with respect to Technology}

COVID-19 made a great change in all lives of the world individually and economic development of almost all nations globally. Even though it has changed the lives of us technologically in some following ways:

- Online shopping: Even though, Online shopping was being done for cosmetics and fashion products, COVID-19 context made people to buy the things differently. It is quite different among the women since they are searching to buy groceries for their home and this is more safe than direct purchase. In some countries, robot deliveries are encouraged for such online purchasing things - raw material, foods, and other home usages.

- Digital Payments: Indian Government has been taking numerous measures to encourage digital payments and as a part of the 'Digital India' campaign, the government aims to make a 'Digitally Empowered Economy' that means 'Faceless, Paperless, and Cashless. There are number of types and modes of digital payments available and they include the use of debit or credit cards, internet banking, mobile wallets, digital payment apps, Unified Payment Interface (UPI) service, Unstructured Supplementary Service Data (USSD), Bank prepaid cards, mobile banking, etc. Of course, this pandemic made that campaign 'Digital India' to a great success.

- Work at Home / Remote Work:Inpandemic period, most of the employees are instructed to work at home and it is being enabled by available technologies - virtual networks, voice over internet protocols, virtual meeting, cloud technology, work collaboration tools and even facial recognition technologies that enable the persons to appear before a virtual background to protect the privacy of their home environment; also these types of interactions and communication helps in save time and provide flexibility and employers are really doing, completing and reporting their assigned work on time, it may be criticized as they are all fear of saving their job security. On the other hand, technology is playing a pivotal role not only in commercial and IT sectors, and also made a tremendous impact on nature of dimension of all educational practices to great extent.

- Online and Distance Learning:It should be accepted that all the educational institutions are not much use of technologies in teaching-learning process and other extensional activities along with research like now. Before this critical context, the teachers, organization, administration may use appropriate technologies for communicating students to convey the important messages like admission notifications, result publications, examination clarification and common news for further actions of steps in their programme, but the situation changed everything Online classes are being done most of the private schools and governments schools are under the process to execute; higher educational institutions are all doing same along with other activities - research viva-voce examinations for research students, and extension programmes like workshops, in-service training, seminars and meetnational or international level virtually. In this case, distance learning is pronounced as correspondence course in prior; distance learning through virtual interaction is naked as online learning and it is needed and unavoidable too. It is being 
done successfully to some extent without deviation in the academic activities among students and teachers. Thanks to technological advance with affordable cost of accessibility with smart phone society, it made this task practicable and applicable to our nation effective.

- Telehealth: During this pandemic, apart from this infectionCOVID-19, peoples are also suffered by many diseases and health problems. Technology and simply technoliteracy really made them attentive in contacting the doctors through online and interaction through video-calls, they got suggestions, recommendations and eprescriptions to solve their problems easily.

- Online Entertainment:COVID-19 situation, services like Hot Star, Amazon Prime and Netflix have been seen increase $82.63 \%$ in spending their time for entertainment; other media like You Tube has been $20.5 \%$ surge in subscribers in the country and it garnered over 300 billion views in the first quarter of 2020 and has been growing at a rate of $13 \%$ since the fourth quarter of 2019. As per the KPMG (International Cooperative is a multinational professional services network called Klynveld Peat Marwick Goerdeler) project titled "Digital Billion" trajectory of India is set to accelerate significantly by virtue of the lockdown. It shows that this above \% of viewing or using media or mode through which entertainment are not being seen just due to the addition of new users but also because of the increasing comfortability and confidence of existing digital citizenry. Hence, this period is being set for a new battle of dominance amongst above streaming services, other entertainment platforms in other forms of at home entertainment services to make people comfortable and make it easy adaptive in future.

\section{Impact of COVID-19 on Women in General Perspective}

In addition to restrict or rollback girls and women's access to essential sexual and reproductive health rights, economics challenges during the outbreak pose a serious threat to young women's work and business activities and expose them to increase the risk of exploitation and abuse. Of course, girls and young women are being facing severe economic shocks and striving to move on high-risk work for their economic survival. In the case of home-makers, they should play their role doubled during this period - have to take care of family health, have to confine the expenditure within the very limited money, take care of their children home study through online mode, etc., this leads to high pressure on women's responsibility whether they belong to employee sector or home-maker sector, definitely they are in need of psychological confident and emotional support from their organization and the family members appropriately to do their duty pleasantly at least. In this scenario, it is very important to have some tecno-literacy to make their work smart and to make their time productive. Here, it is not meant that technologies take part all women's role and but they make them compete the need of the sounding people whether they are the working organization or family members. It is well known fact that a person who may not use all the technologies and communications around them, but she or he should aware of such things to make her/his alive authentication in this digital era. 
It is quite known that women were being found the COVID-19's status and its infectives ratios through the live-news; next, they try to find the websites or WhatsApp groups for home delivery of their required groceries; then they trying to watch YouTube for cooking different dishes for their children; in the next level, they were finding the channels for entertainments; in successive attempt, they are attending their children' online classes now for their guidance along with updating of COVID-19 vaccination news. It will be soon achieved finally they are in position to search online job since they are all attained required techno-literacy. In this juncture, it should be noted that social media also influencing more on their concentration to some extent. The above development may be occurred in other aspects too among other academicians, professionals' activists, and other fields women to a great extent. These above are all not happening among all the women in nation or world, there may be lot of women do not know even the aware of COVID-19 at least. The techno-literacy is not only the rights of women belonging to urban and developed/developing countries, it is also be developed and enriched to make them active and known of happening around them safely.

\section{Conclusion}

This COVID-19 has profoundly demonstrated the importance of digital readiness which allows us to make our life trying become routine as much as possible during this pandemic. In addition to IT sectors, all the departments and sections globally moving towards techno-based work culture in all perspectives. As per BBC reports, an estimated million people will lose their jobs due to COVID-19 and hence the financial burden often falls on the most vulnerable in society. It also be accepted that technologies also skipped many employers by work at home scheme at this period; simultaneously employers are being saved by these information and communication technologies too. Digitalization and pandemics have accelerated changed to job available to humans in any society. Hence, how to alleviate the impact on larger workforce and the most vulnerable is the burning issue across all industries and countries that deserves not only attention but also a timely and human-cantered solution to make settled without punishing directly or indirectly anyone. In this respect, techno-literacy prepares individual to make well-informed choices in their role as consumers in all dimensions - men, women, students, institutions, organization, system, etc. The situation may help or destroy a person by means of her/his perception and realization of that context, but this context made a different changes throughout the world in different perspectives, but it made somewhat techno-literacy and its development among the women to some more extent and its required too; technoliteracy is not a course, it is skill or key to get into enter the techno-world definitely.

\section{References}

1. http://purposefultechnology.weebly.com/why-is-digital-literacy-important.html

2. https://assets.publishing.service.gov.uk/government/uploads/system/uploads/attac hment_data/file/318899/Education-guidance-note-partA.pdf

3. https://content.timesjobs.com/can-digital-literacy-promote-women-empowermentanswer-lies-here/articleshow/63476443.cms

4. https://igsss.org/blog/the-strength-of-women

5. https://kashmirreader.com/2020/06/01/the-importance-of-digital-literacy-forwomen/ 
6. https://looker.com/blog/data-of-women-education-and-literacy-around-the-world

7. https://opentextbc.ca/womenintheworld/chapter/chapter-2-women-and-education/

8. https://oxfamilibrary.openrepository.com/bitstream/handle/10546/122765/bkchanging-perceptions-part-ii-010191-en.pdf?sequence $=26 \&$ isAllowed $=y$

9. https://shodhganga.inflibnet.ac.in/bitstream/10603/18794/8/08_chapter1.pdf

10. https://www.healthshots.com/mind/are-women-stronger-than-men-here-are-8scientific-facts-to-put-this-debate-to-rest/

11. https://www.itu.int/en/ITU-D/Digital-Inclusion/Women-and-

Girls/Documents/ReportsModules/Special\%20report\%20on\%20digital\%20literacy\% 20for\%20Women\%20Girls.pdf

12. https://www.ncbi.nlm.nih.gov/pmc/articles/PMC2528798/

13. https://www.ohchr.org/documents/publications/factsheet23en.pdf

14. https://www.researchgate.net/publication/240596182_Technoliteracy

15. https://www.researchgate.net/publication/323825502_Impact_of_Poverty_on_Educat ion_in_India

16. https://www.researchgate.net/publication/44826376_What_Poverty_Does_to_Girls'_E ducation_The_intersection_of_class_gender_and_policy_in_Latin_America/link/543fbb d00cf21227a11b3507/download

17. https://www.theindiaforum.in/article/what-s-different-about-covid-19-crisis

18. https://www.thetechedvocate.org/digital-literacy-important-lifelong-learning-tool/

19. https://www.who.int/violence_injury_prevention/violence/norms.pdf

20. https://www.worldbank.org/en/topic/girlseducation

21. https://www2.ohchr.org/english/issues/development/docs/girlseducation.pdf 


\title{
HOW DO WOMEN VIEW THE ONLINE LEARNING OF THEIR CHILDREN ? A STUDY OF ALAPPUZHA DISTRICT

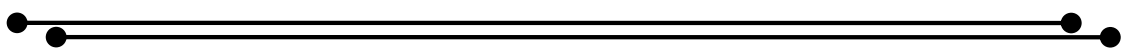

\author{
Dr. Pradeep Kumar B \\ Assistant Professor of Economics, \\ Government Arts \& Science College, Ambalapuzha
}

\begin{abstract}
This paper discusses the issues of online education from the perspective of women, an important agent in the education system in their capacity of mothers. The study enquires into the issues of college going students in the Alappuzha district of Kerala state. The study has found that despite the low economic profile of households, parent give utmost importance to the online education of their children. Most of them have ensured that their children have necessary gadgets and internet services to access online classes. Only 30 percent of the women opine that online education has added burden to their household budget. 60 percent of women appear to have been satisfied with the online classes.
\end{abstract}

Keywords: Online Education, Content. UGC, Household Budget, Women Education, Women assistance.

Covid-19 has created a panic condition elsewhere in the world irrespective of the economic and social condition of the people. It has affected the education sector severely(Bose 2020). Schools and colleges in almost all affected countries have been remaining closed for many months, and it is understood that it will be so for the coming days as well. In this circumstance, educational institutions have shifted to online mode of learning using different online video conference platforms and social media. Although its success remains questioned, students and other stakeholders of the education system have been forced to continue with the online learning as there is no alternative to this. In India, University Grants Commission, Ministry of Human Resource Development and State governments have issued directions to the procedure to be followed in online learning classes(UGC 2020).

Online learning is a new experience to a vast majority of students, teachers and parents. It makes face to face physical interaction in classroom redundant(Segaren 2020). As students and teachers find it increasingly difficult to reach educational institutions owing to country wide and micro lockdowns, they seek to shift to online modes to discuss syllabus based curriculum. Meanwhile universities with the continuance of exams have shown that academic activities especially exams are likely to persist amidst lockdown and the social distancing. Therefore, it has become imperative for teachers, students and parents that they should resort to the online teaching modes and complete the syllabi as prescribed by the Universities.

Other academic exercises have been progressing on the same lines. Recently, many colleges and institutes have come out with the Webinars and Online Conferences discussing important academic things ensuring the presence of all beneficiaries. Even certificates of participation and presentation have been issued to those attending the conferences. These academic exercises and discussions will also continue in the near future as well if the present condition does not evade itself.

Despite the benefits that the online teaching promises in the Pandemic condition, it has created unprecedented apprehensions in the minds of all stakeholders in the education 
system(Chari 2020). It is generally believed in the household, women take more care in the education of children(World Bank 2017). Studies have proved that there exists positive and strong correlation between the education of the women in the household and their children(Hoarding, Pamela and Diane 2015). Moreover, mothers' interest in the education of their children influences the learning outcome and the progress of the children. Therefore, it is likely that the mothers are to be more conscious about the success and failures of children who are undergoing the newer experiences of online learning. In this circumstance, the present study intends to focus on different aspects of online learning from the perspectives of the mothers of the college going students.

\section{Methodology}

The present study is based on primary data collected from the mothers of selected colleges in the Alappuzha district of Kerala state. Questionnaires were sent using the Google form in the whatsaap groups of students and they were asked to record the responses of their mothers and submit the same. Questionnaires were sent to 250 selected students and out of that 228 responses were received. These data was analyzed using appropriate statistical software. Only tabulation and percentages were employed in the present study.

\section{Analysis of Data and Important Findings Employment}

Among the economic factors that influence the education of the children, employment of parents assumes importance. Unsurprisingly, it is obvious that most of the mothers are housewife (83.7 per cent) and only 4.8 per cent are working in the government sector (Table No. 1). This shows that employment wise, the mothers are not empowered as they stay inside the home focusing on caring works.

Table 1: Employment wise distribution of Women

\begin{tabular}{|l|c|c|}
\hline & per cent & Cumulative per cent \\
\hline Employed as Casual workers & 6.7 & 6.7 \\
\hline Employed in Gov. Sector & 4.8 & 11.5 \\
\hline Employed in Private Sector & 4.8 & 16.3 \\
\hline Housewife & 83.7 & 100 \\
\hline \multicolumn{1}{|c|}{ Total } & 100 & \\
\hline
\end{tabular}

Source: Primary Survey, 2020

Looking at the occupation of their spouses, it is seen that most of them are reported to have been engaged in casual works and other type of works (81.7 per cent). While 9.6 per cent of the spouses find employment in private sector only 8.7 per cent are employed in the government sector (Table No.2). 
Table 2: Occupation wise distribution of Spouse

\begin{tabular}{|c|c|c|}
\hline Occupation & Valid Per cent & Cumulative per cent \\
\hline Any other & 48.1 & 48.1 \\
\hline Casual worker & 33.7 & 81.7 \\
\hline Working in Gov. Sector & 8.7 & 90.4 \\
\hline Working in Private Sector & 9.6 & 100 \\
\hline Total & 100 & \\
\hline
\end{tabular}

Thus it is clear that employment wise the condition of the parents of these students does not appear to be good. Many do not have regular and standard employment opportunities. Of course, this will have far reaching consequences on the progress of students especially in the higher education system where the cost of education has been skyrocketing. Again, it would not be much surprising that 60 per cent of these households hold BPL (Below Poverty Line) ration cards (Figure No.1).

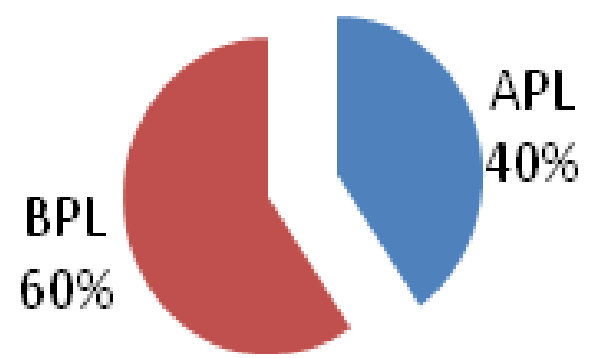

Figure 1 - APl/BPL status of the Households

Nevertheless, the low income households do not seem to be compromising on the education needs of their children. Most of the students (60.6 per cent) do hold gadgets having less than Rs. 10000 while not less than 32.6 per cent have bought gadgets worth between Rs.10000 and 15000 prices (Figure No.2).

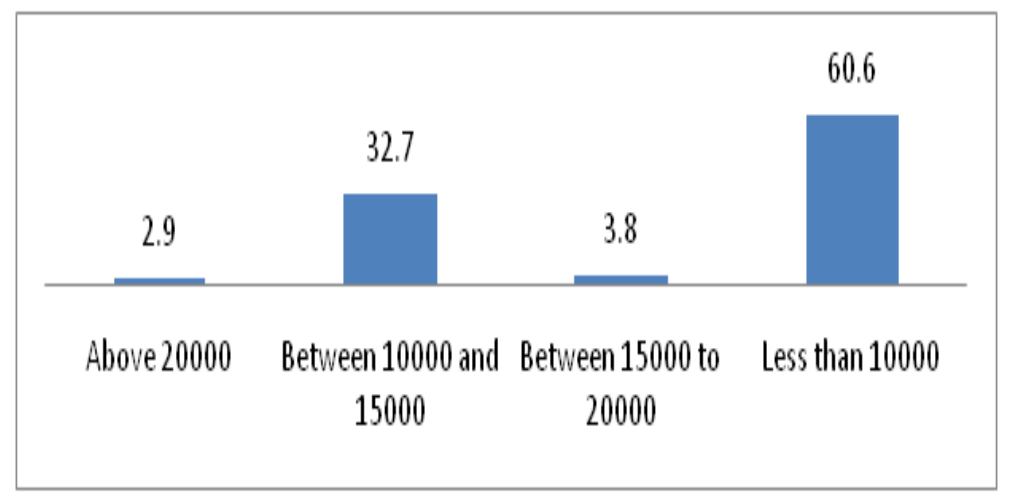

Figure 2 - Price Range of Gadgets

It is quite interesting to note that an overwhelming per cent of respondents ( 99 per cent) use mobile phones to access the online classes (Figure No2). 


\section{Mobile}

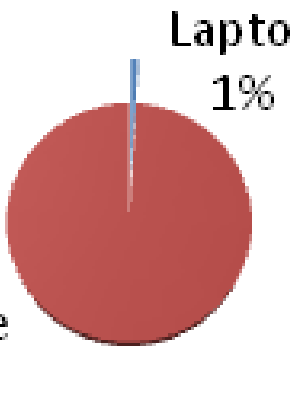

Figure 2 - Gadgets which the students use

Smart mobile phones having the requisite capacity to install and run applications of different online platforms like Google Meet and Zoom are generally of high prices, and these parents being economically not sound, have had to borrow money from different sources to buy mobiles for their students. While 55 per cent somehow managed it without resorting to borrowings bearing interest rates, 45 per cent had to borrow money to buy gadgets of requisite qualities (Figure No3).

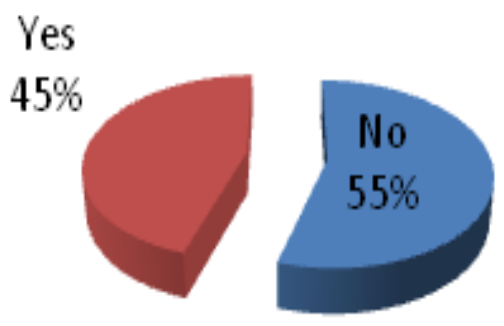

Figure 3 - Did you borrow money to buy Gadgets

This shows the highest interest that the parents show in the education of their children and evidently this interest is born out of the education process that they went through although they might not have been properly employed despite having average education levels.

Table 3: Education Attainment of Women

\begin{tabular}{|l|c|c|}
\hline & per cent & Cumulative per cent \\
\hline any other & 8.7 & 8.7 \\
\hline Degree & 14.4 & 23.1 \\
\hline Plus Two or Pre-Degrees & 27.9 & 51 \\
\hline Post-Graduation and above & 1 & 51.9 \\
\hline SSLC Total & 48.1 & 100 \\
\hline \multicolumn{1}{|c|}{ Tol } & $\mathbf{1 0 0}$ & \\
\hline
\end{tabular}

This is evident from the fact 48 per cent of women (mothers of students) are qualified in SSLC exams while 14 per cent are graduates (Table No.3). Further it is interesting to observe that Airtel is the most preferred internet service provider of the students (Table No4). 
Table 4: Service Providers

\begin{tabular}{|c|c|c|}
\hline Service provider & Per cent & Cumulative Per cent \\
\hline Airtel & 31.7 & 31.7 \\
\hline Anyother & 10.6 & 42.3 \\
\hline BSNL & 3.8 & 46.2 \\
\hline Idea & 27.9 & 74 \\
\hline Jio & 26 & 100 \\
\hline Total & 100 & \\
\hline
\end{tabular}

Students of this generation are tech savvy people compared to their parents, and hence they normally do not require any technical assistance from their parents in attending the online classes. Nevertheless, in certain circumstances parents take effortand time in helping their wards to effectively use the online class platform o their benefits. It is of course curious to know the help that the parents render to their wards in this regard. In this study, it has been found that 32.7 per cent of mothers sometime help their students while only 24 per cent of them never offer any help to their children (Table No.5).

Table 5: How often do you help your child (in online learning)

\begin{tabular}{|l|c|c|}
\hline & Per cent & Cumulative Per cent \\
\hline Always & 25 & 25 \\
\hline Never & 24 & 49 \\
\hline Often & 6.7 & 55.8 \\
\hline Rarely & 11.5 & 67.3 \\
\hline Sometimes & 32.7 & 100 \\
\hline \multicolumn{1}{|c|}{ Total } & 100 & \\
\hline \multicolumn{2}{|c|}{} \\
\hline
\end{tabular}

Online classes have reduced the expenditure on the part of the institutions, but the burden has apparently been shifted to the parents as they have to provide necessary gadgets and reliable internet connection for their children. It is quite unsurprising that 31.7 per cent of women have agreed to the opinion the statement that online learning has added to the financial burden of the household. At the same time, 30.8 per cent do not share this view (Table No.6). This is because of the fact that gadgets and internet connections were accessed by the parents and students even before the necessity of online classes emerged on account of the social distancing and lockdown. But for those who did not have such gadgets, the necessity of buying these things to engage in online classes might have put constraints on their household budgets.

Table 6: Online learning has added to the financial burden of the household

\begin{tabular}{|c|c|c|}
\hline $\begin{array}{l}\text { Online learning has added to } \\
\text { financial burden }\end{array}$ & Per cent & Cumulative Per cent \\
\hline Agree & 31.7 & 31.7 \\
\hline Disagree & 30.8 & 62.5 \\
\hline Neutral & 24 & 86.5 \\
\hline Strongly agree & 2.9 & 89.4 \\
\hline Strongly disagree & 10.6 & 100 \\
\hline Total & 100 & \\
\hline
\end{tabular}


Women especially when they take much caring jobs besides assisting the students in their online classes actually are forced to multitasking in everyday. In this case, time management of women in household affairs matters a lot. We may often believe that when children remain in homes without attending classes in College, household regular activities of women may get affected. But the true story runs contrary to this. In the present study, only 25 per cent of women agree that their household works get affected whereas 42.3 think otherwise (Table No.7)

Table 7: Household work gets affected due to online assistance given to children

\begin{tabular}{|c|c|c|}
\hline Household gets affected & Per cent & Cumulative Per cent \\
\hline agree & 25 & 25 \\
\hline disagree & 42.3 & 67.3 \\
\hline neutral & 20.2 & 87.5 \\
\hline strongly agree & 1.9 & 89.4 \\
\hline strongly Disagree & 10.6 & 100 \\
\hline Total & 100 & \\
\hline
\end{tabular}

Children can help mother and others in household in many ways, and of course they while being grown up can add values to the life of their fellow being by engaging in productive works. Recently, Kerala government has made changes in the timings of colleges keeping in mind this aspect. The present study reveals that students who keep themselves aloof in times of social distancing and micro lockdown in view of the spreading nature of Covid-19 virus are seemed to be helping their parents in household work. An overwhelming majority of respondents agree with the statement that students help them in household work as they do not have to attend colleges (Figure No7).

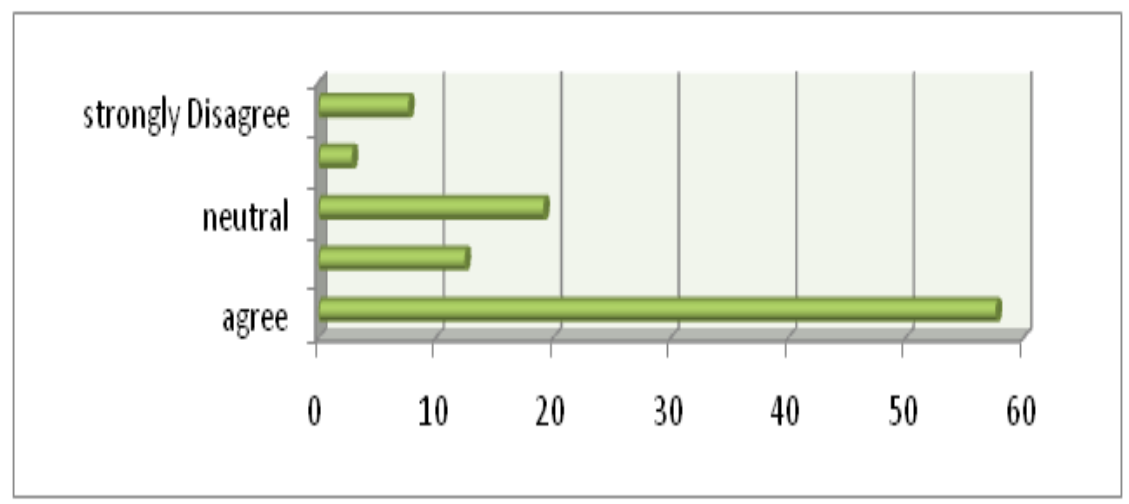

Figure 5- Children help in household work as they do not have to go to colleges

Two aspects still remain unaddressed: One is the fitness of online education to cater to the needs of the students. We know that online education can hardly be a perfect substitute of the classroom learning which has more added values and qualities. But given the present pandemic condition, we are left with no option but to choose online education as an alternative, and many have taken the same path willingly or unwillingly. Capturing the 
positivity's of the online classes is something of a herculean task but instead we attempt to embrace everything about this in one simple thing: whether it is good for your child, and to the surprise, the study has revealed that 44.2 per cent agree and 15.4 strongly agree with the view that it is good for their children while, it should not be undermined that, 19.2 percent disagree also. But, since agree plus strongly agree outweighs other responses, online classes can be taken to be good for students provided the present condition, according to the women of the surveyed students (Table No.8)

Table 8: Online education is good for my child

\begin{tabular}{|c|c|c|}
\hline Online education is good & Per cent & Cumulative Per cent \\
\hline agree & 44.2 & 44.2 \\
\hline disagree & 19.2 & 63.5 \\
\hline neutral & 19.2 & 82.7 \\
\hline strongly agree & 15.4 & 98.1 \\
\hline strongly Disagree & 1.9 & 100 \\
\hline Total & 100 & \\
\hline
\end{tabular}

Goodness is something related to the outcome of the process whereas satisfaction captures the positive aspects of the whole process. Hence, the present study went to probing whether the women from the surveyed household are satisfied with the online classes or not. Satisfaction takes into account many things, like the timing of classes, mode of delivery of content, quality of internet access, and the whole process through which learning takes place, of course. Needless to say, much to the surprise of many, 60.6 percent of households feel satisfied with the online classes, which by any count points towards the success of the online learning method under the present circumstances (Table No9).

Table 9: Are you satisfied with the online education?

\begin{tabular}{|c|c|c|}
\hline $\begin{array}{l}\text { Are you satisfied with } \\
\text { online education }\end{array}$ & Per cent & Cumulative Per cent \\
\hline dissatisfied & 20.2 & 20.2 \\
\hline satisfied & 60.6 & 80.8 \\
\hline unsure & 7.7 & 88.5 \\
\hline very dissatisfied & 3.8 & 92.3 \\
\hline very satisfied & 7.7 & 100 \\
\hline Total & 100 & \\
\hline
\end{tabular}

\section{Conclusion}

Thus it is evident that women take utmost care in the online education of their children. The study has found that despite the low economic profile of households, parentsspend money to meet the online education needs of their children. Most of them have ensured that their children have necessary gadgets and internet services to access online classes. Only 30 percent of the women opine that online education has added burden to their household budget while 60 percent of women appear to have been satisfied with the online classes. 


\section{Works Cited}

1. Bose, Ranjan Pratim. The Covid challenge to Indian school education: Reform or perish. Kolkota: Business Line, 2020.

2. Chari, Rashmi. Challenges of Quality in Online Learning. Edutrends in India, 2020.

3. Hoarding, Jessica, Morris Pamela, and Hughes Diane. "The Relationship between Maternal Education and Childrens' Academic Outcomes: A Theoretical Framework." Journal of Marriage and Family, 2015.

4. Segaren, Sharuna. 5 major benefits of online learning. SI News, 2020.

5. UGC. https://www.ugc.ac.in/subpage/covid_advisories.aspx. July 20, 2020. (accessed July 2020).

6. World Bank. https://www.worldbank.org/en/topic/girlseducation. September 25, 2017. 